\title{
HETEROSE, DEPRESSÃO POR ENDOGAMIA E VARIABILIDADE GENÉTICA ASSOCIADAS À SELEÇÃO E OSCILAÇÃO GENÉTICA NAS POPULAÇÕES DE MILHO BR-105 E BR-106
}

\author{
GABRIEL DEHON SAMPAIO PEÇANHA REZENDE \\ Engenheiro Agrônomo
}

Orientador: Prof. Dr. CLÁUDIO LOPES DE SOUZA JÚNIOR

Tese apresentada à Escola Superior de Agricultura "Luiz de Queiroz", Universidade de São Paulo, para obtenção do título de Doutor em Agronomia, Área de Concentração: Genética e Melhoramento de Plantas.

PIRACICABA

Estado de São Paulo - Brasil

Abril - 1997 
Dados Internacionais de Catalogação na Publicação (CIP) DIVISÃo DE BIBLIOTECA E DOCUMENTAÇÃO - Campus "Luiz de Queiroz"/USP

Rezende, Gabriel Dehon Sampaio Peçanha

Heterose, depressāo por endogamia e variabilidade genética associadas à seleção e oscilaçāo genética nas populaçōes de milho BR-105 e BR-106 / Gabriel Dehon Sampaio Peçanha Rezende. - Piracicaba, 1997.

$112 \mathrm{p}$.

Tese (doutorado) - Escola Superior de Agricultura Luiz de Queiroz, 1997. Bibliografia.

1. Endogamia 2. Heterose 3. Milho 4. Seleção recorrente 1. Titulo 


\section{HETEROSE, DEPRESSÃO POR ENDOGAMIA E VARIABILIDADE GENETICA ASSOCIADAS Ả SELEÇÃO E OSCHLAÇÃO GENÉTICA NAS POPULAÇÕES DE MIIHO BR-105 E BR-106}

GABRIEL DEHON SAMPAIO PEÇANHA REZENDE

Aprovada em: 27/06/1997.

Comissåo Julgadora:

Prof. Dr. Cláudio Lopes de Souza Júmior

ESALQ/USP;

Prof. Dr. Isalas Oltvio Geraldi

ESALQ/USP;

Prof. Dr. Roland Vencovsky

ESALQ/USP;

Prof. Dr. César Augusto Brasil Pereira Pinto

UFLA;

Pesq. Dr. Antônio Carlos da Silva

Sementes Agroceres S/A.

Prof. Dr. CLAUDIOLOPES DE SOUZA JÚNIOR

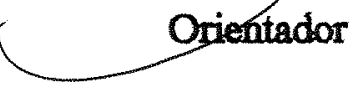


A Deus, causa primána de todas as coisas.

Minha esposa Ingrid e minha filha Gabriela.

Meus pais Antônio e Telma.

Meus irmãos. 


\section{AGRADECIMENTOS}

À Escola Superior de Agricultura "Luiz de Queiroz" (ESALQ/USP), pela oponmidade concedida.

Ao Conselho Nacional de Desenvolvimento Cientffico e Tecnológico (CNPq), pela concessão da bolsa de estudos.

À Fundação de Amparo à Pesquisa do Estado de São Paulo (FAPESP), pelo auxdio finmceiro destinado à realização deste projeto.

A Sementes Agroceres S/A, pela disponibilidade demonstrada na contuçåo do experimento localizado em Andradas - MG.

Ao Professor Cláudio Lopes de Souza Júmior, que em sua sábia orientação soube conciliar capacidade, dedicação, confiança e amizade.

A todos os membros da Comissão Julgadora, pela disponibilidade e pelas valiosas contribuiçőes transmitidas.

A todos os Professores da ESALQ/USP, que durante este aprendizado contribuiram de alguma maneira para meu crescimento profissional.

A todos os colegas do curso de Genética e Melhnramento de Plantas, pelo grande companheirismo vivenciado durante todos os passos desta caminhada.

Ao amigo Daniel Furtado Ferreira, pela colaboraçăo e, principalmente, pela sincera amizade.

A todos os funcionários do Departamento de Genética, pelo convivio e atenção. Particularmente a Antônio Jucelino Desidério e a Ariberto Saares de Oliveires pela expressiva ajuda na conduça dos experimentos. 
Aos companheiros do Centro de Pesquisa e Tecnologia da Aracruz Celulose S/A, em especial Fernando de L. G. Bertolucci e Ergilio Cláudio-da-Silva Júnior, pelo apoio e interesse empregados para que este trabalho fosse concluido com êxito.

Aos meus pais Antonio Ferreira de Rezende e Telma Sampaio Rezende, pela tema atençåo manifestada em suas incessantes oraçôes.

A minha esposa Ingrid Lameiras de Soura Regende, que mesmo nos momentos mais dificeis dedicou-se como mulher e companheira à conquista deste ideal.

Finalmente, a Deus, que tudo penmitiu. 


\section{SUMÁRIO}

Página

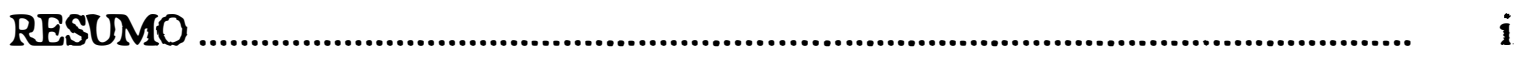

SUMMARY .................................................................................................. iii

1. INTRODUÇÃO

2. REVISÃO DE LITERATURA ……………………...................................... 4

2.1. Seleçд̃o recontente em milho ............................................................................

2.1.1. Heterose, depressão por endogamis e vanabilidade genética associadas à seleção recorrente em milho ................................................................. $\quad 8$

2.2. Bases teoricas da oscilaf̧a genética ................................................................

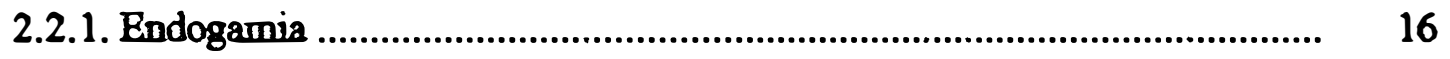

2.2.2. Médias e variâncias genéticas ............................................................... 21

2.3. Efeitos da seleção e da oscilação genética em milho ......................................... 24

3. MATERIAL E METODOS ............................................................................ 32

3.1. Material genético .................................................................................... 32

3.2. Tratamentos e procedimentos experimentais .................................................... 33

3.3. Analise estatistico-genética dos dados ......................................................... 35

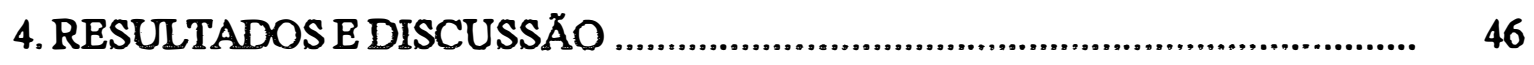

4.1. Efeitos da seleção e da oscilação genética nos componentes de médias, heterose e depressæ̋o por endogamia .................................................................. 46

4.2. Efeitos da seleção e da oscilaçåo genética na variabilidade genética ................. 64 
5. CONCLUSOES ................................................................................... 74

TABELAS

REFERENCIAS BIBLIOGRAFICAS ........................................................... 101 


\section{HETEROSE, DEPRESSÃO POR ENDOGAMIA E VARIABILIDADE GENETTICA ASSOCIADAS À SELEÇÃO E OSCILAÇÃO GENETICA NAS POPULAÇO์ES DE MILHO BR-105 E BR-106}

Autor: GABRIEI DEHON SAMPAIO PEÇANHA REZENDE Orientador: PROF. DR. CLAUDIO LOPES DE SOUZA JU'NIOR

\section{RESUMO}

Para se investigar os efeitos da seleçăo e da oscilaçăo genótica sobre a heterose e a depressão por endogamia, as populaçoes de milho BR-105 e BR-106, e suas respectivas variedades sintéticas IG-3 e IG-4, obtidas após um ciclo de seleçåo recorrente reciproca com utilizaçăo de elevadas intensidades de seleçăo, foram intercnuzadas em sistema dialélico, autofeamdadas e multiplicadas, compondo 14 tratamentos avaliados pelo delineamento de blocos casualizados, em três locais, com dez repetiçðes por local. Paralelamente, procurou-se verificar os efeitos da seleção e da oscilação genética sobre a variabilidade genética dos materiais, pela avaliaçăo de 169 progênies de irmåos germanos interpopulacionais do cruzamento entre as populaçöes BR-105 e BR-106, e de 169 progênies de irmåos germanos interpopulacionais do cruzamento entre os sintéticos IG-3 e IG-4, através de dois látices $13 \times 13$, cada um com metade das progênies de cada crumamento, instalados em dois locais, com duas repetiçס̄es por local. Os dados obtidos 
ao ntvel de métias de parcelas para os caracteres peso de espigas, altura da planta e da espiga, posição relativa da espiga na planta e indice de prolificidade foram utilizados na obtençân de estimativas de componentes genéticos de médias e variâncias, de acordo com motodologias estatisticas especificas.

O processo seletivo foi eficiente em melhorar a media e a heterose do hibrido interpopulacional e em melhorar a média e redurir a depressão por endogamia da populaçă BR-105, mas não foi efetivo em melhorar a populaçăo BR-106, que apresentou decréscimo em seu desempenho individual e manteve seus níveis de depressăo par endogamia, para a maioria dos caracteres avaliados. A magnitude das alteraçoes observadas na heterose do hibrido interpopulacional e na depressão por endogamia das poptulaçőes foi funçåo de modificaçőes nas frequências de alelos de efeito dominante nas populaçð̄es per se e no hibrido interpopulacional, e principalmente, fumçăo dos efeitos da redução na heterozigose por oscilaçåo genética, atuando significativamente no sentido de redurir a expressão da maioria das caracteristicas, em ambas as populaçőes.

Apesar do tamanho efetivo restrito das variedades sintéticas, a interpopulaçåo IG-3 x IG-4 não apresentou diferenças significativas em relaçăo a interpopulaça BR-105 x BR-106, no que se refere à expressão da variabilidade genética e, consquremememte da resposta esperada à seleçåo, para a maioria das caractenisticas avaliadas. Além disso, o processo de melhoramento do hibrido imterpopulacional se dev sem que houvesse perda de normalidade e presença de assimetrias na distribuição dos dados indicando, portanto, que o efeito conjunto da seleção e da oscilação genética não afetou significativamente os padróes de variaçåo das progénies interpopulacionais, garantindo a integridade da variabilidade genética necessária para a realizaçăo de fưturos ciclos de seleção. 


\title{
HETEROSIS, INBREEDING DEPRESSION AND GENETIC VARIABILTY \\ AS AFFECTED BY SELECTION AND GENETIC DRIFT \\ IN BR-105 AND BR-106 MAIZE POPULATIONS
}

\author{
Author: GABRIEL DEHON SAMPAIO PEÇANHA RRZENDE \\ Adviser: PROF. DR. CLAUDIO LOPES DE SOUZA JÚNIOR
}

\section{SUMMARY}

To investigate selection and genetic drift effects over heterosis and inbreeding depression, BR-105 and BR-106 maize populations and their respective synthetics IG-3 and IG-4, obtained after one cycle of reciprocal recurent selection with high selection intensities, were intermated in a diallel system, selfed and multiplied. The resulting 14 treatments were evaluated through RCB design with ten replications, across three locations. Concurrently, selection and genetic drift effects over genetic vaniability were investigated by evaluating 169 full-sib progenies between BR-105 and BR-106 populations, and 169 full-sib progenies between IG-3 and IG-4 synthetics. Two $13 \times 13$ lattices were used each one with half the progenies of each cross, with two replications and across two locations. Data obtained on a plot mean basis for ear weight, plant and ear heights, plant relative ear position and prolificity index were used to estimate genetic components of means and variances, according to specific statistical procedures. 
Reciprocal recurrent selection was efficient at improving the mean and heterosis of the interpopulation cross and at improving the mean and rectucing inbreeding depression of BR-105 population, but did not improve BR-106 population, which presented decrease in its individual performance and sustained its inbreeding depression level, for most traits. The magnitude of the observed changes in heterosis and inbreeding depression was determined by modifications in the frequencies of alleles with dominant effect on the populations per se and on the interpopulation cross, and especially by heterozigosity rectuction due to random genetic drift, significantly acting to rechuce expression of most traits on both populations.

Despite the synthetics restricted effective population size, there was no significant differences between the interpopulations IG-3 x IG-4 and BR-105 x BR-106 regarding the expression of genetic variability, and as a result, of the expected response to selection, for most traits. Besides, the improvement of the interpopulation hybrid was accomplished without loss of normality and presence of skewness in data distribution, suggesting that selection and genetic drift effects did not act upon the interpopulation full-sib progeny variation patterns, ensuring the genetic variability required by the completion of future cycles of selection. 


\section{INTRODUÇÃO}

Os diversos métodos de seleçăo recontente, originalmente propostos por JENKINS (1940), HULL (1945) e COMSTOCK et al. (1949), tem sido amplamente utilizados para promover o melhoramento de populaçðee na cultura do milho. Este processo, definido basicamente como avaliaçăo, seleça e secrmbinaçăo de genótipos superiores por sucessivas geraçőes, tem como objetivo aumentar gradualmente a frequência de alelos favoráveis nas populaçð̄es e, ao mesmo tempo, mamter a variabilidade genética em níveis satisfatórios para que a seleçăo possa ser praticada com eficiência por um longo periodo de tempo (PATERNIANI \& MIRANDA FILHO, 1987).

Estes métodos se constituem, também, na base para o sucesso na obtenção de hibridos superiores e de linhagens endogâmicas altamente prohutivas que minimizem o custo da semente hibrida, objetivo final dos programas de melhoramento de milho. Tal afirmação fundamenta-se na psemissa de que as performances das linhagens e de seus bubridos são determinadas, respectivamente, pelo desempenho das populaçð̄es per se e dos cruzamentos interyopulacionais (SOUZA JR., 1993).

Várias pesquisas mostram que a heterose em cnizamentos e a depressăo por endogamia de populaç̧̄es de milho submetidas à seleç̧̊o recorrente, parametros que refletem, respectivamente, o comportamento dos hibridos e das linhagens retiradas destes 
materiais, sofrem alteraçőes significativas com o decorser do processo seletivo (SOUZA JR., 1985; SOUZA JR. \& MIRANDA FILHO, 1985, 1989; LAMKEY \& SMITH, 1987; HALLAUER et al., 1988). Apesar disso, a variabilidade genética das populações nåo tem se alterado substancialmento ao longo dos ciclos de seleção (COORS, 1988; STUCKER \& HALLAUER, 1992; SCHNICKER \& LAMKEY, 1993; HOLTHAUS \& LAMKEY, 1995).

Deve-se ressaltar, contudo, que o efeito da seleçåo, por si só, nåo é o único fator a provocar alteraçỏes na heterose, depressăo por endogamia e variabilidade genética dos materiais. Mudanças nas frequências alélicas devido à oscilaçåo genética, processo aleatorio resultante da amostragem de gametas, tamberm devem afetar estes parametros, principalmente pela utilização de tamanhos efetivos populacionais recuridos (WRICKE \& WEBER, 1986, FALCONER,1989). Pela aplicaçåo de metodologia genéticoestatistica proposta por SMITH (1979a, b, 1983), tem-se observado que em populaçąes de milho submetidas à seleçåo recontente, a depressão por endogamia devido à oscilação genética apresenta valores elevados e, muitas vezes, proximos aos dos ganhos obtidos com a seleçåo (HELMS et al., 1989; EYHERABIDE \& HALLAUER, 1991; KEERATINUAKAL \& LAMKEY, 1993). Apesar da inovaçåo dessa metodologia e da importância das informaçōes por ela geradas, não existem relatos de sua aplicaçåo em materiais utilizados como germoplasma bésico nos programas de melhoramento de milho conduzidos no Brasil.

Do exposto, foi realizado o presente trabalho com o objetivo de avaliar, atraves da metodologia proposta por SMITH (1979a, b, 1983), e também pela estimaça de companentes de médias, variâncias e parâmetros derivados, os efeitos da seleção e da 
oscilaçåo genética sobre a heterose, depressão por endogamia e variabilidade genética, em duas importantes populaçð̌es de milho submetidas a um ciclo de intensa seleçăo recorrente reciproca, cujos produtos foram duas variedades sintéticas de reduzido tamanho efetivo populacional. 


\section{REVISÃO DE LITERATURA}

\subsection{Seleçāo recorrente em milho}

Para aumentar a probabilidade de obtença de hibridos superiores e de linhagens endogamicas altamente procutivas, objetivo final dos programas de melhoramento de milho, deve-se partir de populafies melhoradas (MIRANDA FILHO \& VIEGAS, 1987), pois as performance das linhagens e de seus hibridos podem ser avaliadas com base no cormpurtamento das populaçes per se e dos cnzamentos interpopulacionais, respectivamente (SOUZA JR., 1993).

Portanto, a base para o sucesso deste tipo de programa reside no melhoramento das populaçäes per se e dos híbridos interpopulacionais, o que se consegue pela aplicaçåo de diferentes métodos de seleção reconrente. Este processo, definido como seleçăo, geraçăo após geraçăo, com intercnuzamento dos materiais selecionados (HULL, 1945), tem como objetivo aumentar gradualmente a frequencia dos alelos favoráveis e, ao mesmo tempo, manter a variabilidade genética das populaçōes ao longo dos ciclos de melhoramento (PATERNIANI \& MIRANDA FILHO, 1987).

Existem basicamente duas modalidades de seleçăo recorrente: intrapopulacional e interpopulacional. Na seleção recnrente intrapopulacional o objetivo principal é o 
melhoramento da populaçăo per se, não sendo avaliado o seu compartamento no cruzamento com outras populaçőes. Neste tipo de seleçåo recorrente, os genótipos de uma populaçă são avaliados com base no desemyenho de suas progênies em experimentos com repetiçőes, e aqueles selecionados são recombinados para gerar uma populaçåo melhorada que é, então, submetida a un novo ciclo seletivo.

Dos vários métodos de seleçåo recorrente intrapopulacional destacam-se a seleçåo massal, baseada no fenótipo dos individuos, e a seleção com uso de progênies, inchuindo progênies de meios immåos, immâos completos e de autofecumdaçă $\left(S_{1}\right.$ ou $\left.S_{2}\right)$. Estes métodos podem ainda se diferenciar no que se refere ao tipo de progênie utilizada na remmbinaçăo dos genótipos supperiores. Assim, no método de seleção com progênies de meios irmåos, a recombinaçăo pode ser feita com sementes remanescentes das progênies selecionadas ou com progênies de autofecumdação $\left(S_{1}\right)$, o que exige a presença de plantas prolificas para a obtençåo dos dois tipos de progênies. Raciocinio análogo aplica-se à seleçåo com progênies de irmãos completos e, finalmente, no caso da seleçåo com progênies endogamicas $S_{1}$ e $S_{2}$, as unidades de recombinaçåo equivalem às unidades de seleçăo, ou seja, progênies $S_{1}$ e $S_{2}$, respectivamente (HALLAUER et al., 1988).

Fica evidente, partanto, que o ganho com a seleçåo varia de acordo com o método utilizado. Infummaçőes detalhadas a respeito destes métodos e comparaf̧äes reférentes ao progresso obtido com a seleçåo são apresentadas por ARIAS (1995), mas deve-se mencionar que na seleçăo recorrente intrapopulacional a resposta direta à seleçåo aparece nas populações per se, e a resposta indireta aparece nos seus respectivos cruzamentos.

No que se refere a seleçåo recortente interpopulacional ou reclproca, ênfase é dada ao melhoramento do hibrido interpopulacional, visando a maximização da heterose 
(MOLL \& STUBER, 1971; HALLAUER et al., 1988). Neste esquema de seleçåo recnuente, os genótipos de cada populaçăo såo avaliados em cruzamentos com genótipos da populaçăo recíproca. As progênies interpopulacionais obtidas são avaliadas em experimentos com repetiçסes e os genótipos de cada populaçå que apresentam melhor capacidade de combinaçăo com a populaçăo reclproca são recombinados entre si, utilizando-se para isso progênies intrapopulacionais. Portanto, cada genótipo deverá produmir obrigatoriamente dois tipos de progênies, uma inter e outra intrapopulacional, buscandase assim o melhoramento da heterose que se manifesta nos cruzamentos e das populaçes per se.

Os tipos de progênies, inter e intrapopulacionais, geralmente utilizadas såo, respectivamente: meios immåos e $S_{1}$; irmåos completos e $S_{1}$; meios irmãos e meios immåos. Como comentado anteriormente, as progênies interpopulacionais são utilizadas como unidades de seleção e as intrapopulacionais como unidades de recombinaçá. Deve-se observar que, em todos os casos, a presença de plantas prolificas é exigida para que se obtenha os dois tipos de progênies (PATERNIANI \& MIRANDA FILHO, 1987).

A resposta à seleção interpopulacional varia de acordo com o método utilizado. VENCOVSKY (1987) apresenta informaçס̋es detalhadas a esse respeito, e os principais resultados obtidos com cada método anteriormente mencionado são abagdados por ARIAS (1995). Ressalta-se o fato de que a resposta direta à seleçăo interpopulacional aparece nos cruzamentos entre populações e a resposta indireta nas populações per se.

Diversos trabalhos envolvendo esquemas de seleça recorrente intra e interpopulacionais, bem como comparaçđes entre eles, mostram que o método interpopulacional tem sido mais eficiente em melhorar a produtividade do hibrido 
interpopulacional e de uma das populaçðes per se, apresentando a populaçă reciproca ganhos nåo significativos ou, até mesmo, decréscimos significativos no rendimento. Já o método intrapopulacional, tem melhorado as populaçoes per se de maneira mais eficiente, ficando o hibrido interpopalacional com menores incrementros na produtividade (MOLL et al., 1978; MOLL \& HANSON, 1984; HELMS et al., 1989).

Estudos teóricos realizados por SOUZA JR. (1993), confirmam as tendencias anterionmente mencionadas, e evidenciam que estes métodos tem falhado em atender de forma ampla aos objetivos dos programas de melhoramento do milho. Diante disso, o mesmo autor sugere a utilização de um método modificado de seleção recorrente, onde uma das populaçð̋es, a que apresenta menor valor médio para o caráter em questão, é utilizada como testadora dela mesma e da populaça reciproca. Portanto, o método apresenta uma aburdagem interpopulacional para a populaça de maior media e intrapopulacional para a populaçă de menor métia

De acordo com SOUZA JR. (1993), a metodologia proposta se apresenta mais eficiente que a seleção intrapopulacional e tão eficiente quanto a seleção interpopulacional para melhorar a populaçăo superior, mais eficiente que a seleção interpopulacional e tão eficiente quanto a seleçåo intrapopulacional para melhorar a população inferior, mais eficiente que a seleção intrapupulacional e menos eficiente que a interpopulacional para melhorar a heterose; e mais eficiente que ambos os métodos para 0 melhoramento do hibrido interpopulacional. Do exposto, no contexto geral, esse método parece ser superior aos métodos tradicionais, o que, segundo o autor, está relacionado às magnitudes de novos componentes genéticos de vanância e covariância por ele sugeridos. Tais evidências foram confirmadas por ARIAS (1995). 


\subsubsection{Heterose, depressāo por endogamia e variabilidade genética associadas à seleção recorrente em milho}

Como consequéncia das mudanças nas frequências alélicas das populaçoes submetidas a seleção recarrente, alteraçoes na heterose, depressão por endogamia e variabilidade genética são esperadas, influenciando diretamente o desempenho dos hifridos e das linhagens endogâmicas derivados destes materiais, bem como a realizaça de ciclos seletivos futuros.

Os resultados de pesquisa relativos aos efeitos da selecão recorrente sobre a heterose não são consistentes, pois enquanto algums trabalhos reportam aumento em seu valor para a producăo de grãos ao longo dos ciclos seletivos, outros evidenciam sua rectuçåo (GENTER, 1973; EBERHART et al., 1973; RUSSELL et al., 1973; PATERNIANI \& VENCOVSKY, 1977; DARRAH et al., 1978).

Com base nessa falta de consistência dos resultados de pesquisa, SOUZA JR. \& MIRANDA FILHO (1985) realizaram um trabalho com o objetivo de estudar, tearicamente, a alteraçăo esperada na heterose pela aplicação dos dois tipos de seleçăo recorrente, intra e interpopulacional, em funçăo das frequeccias alélicas e dos efeitos genotipicos. Verificou-se que, do ponto de vista teórico, a atteraçăo na heterose tende a ser negativa para a seleçåo recorsente intrapopulacional e positiva para a seleçăo interpopulacional, em funçåo desta última fazer uso dos efeitos genéticos aditivos e não aditivos, nos locos para os quais existe divergência entre as populaçð̃es e algum grau de dominância. Posteriormente, outras pesquisas realizadas com base no estudo de 
variâncias e covariancias genéticas intra e intexpopulacionais confirmaram esta tendência (SOUZA JR. \& MIRANDA FILHO, 1989; SOUZA JR., 1993). Deve-se mencionar que resultados não coerentes com o esperado teoricamente podem ser explicados pela ocoméncia de interaçăo de genótipos por ambientes ou de problemas expenimentais na avaliaçåo dos ciclos de seleção (SOUZA JR. \& MIRANDA FILHO, 1985).

A depressão por endogamia tambem tem sofrido alteraçães significativas com o deconter dos processos de seleçå. De maneira geral, tem sido observada, para o carater protuçăo de grảos, uma tendéncia de reduçăo na depressão por endogamia dos materiais submetidos aos diferentes métodos de seleção recorrente (GENTER, 1971; GOULAS \& LONQUIST, 1976; OYERVIDES-GARCLA \& HALLAUER, 1986; HALLAUER et al., 1988; RODRIGUEZ \& HAILAUER, 1988; ODHIAMBO \& COMPTON, 1989).

Estudos teóricos realizados por SOUZA JR. (1985), para seleção reconente intrapopulacional, mostram que, considerando um loco com dois alelos e dominancia completa, a depressão por endogamia só diminui quando a frequência do alelo favorável é superior a 0,5. Se essa frequência for inferior a 0,5, a depressão por endogamia tende a se acentuar com a seleção. Portanto, este modelo teórico explica os resultados citados na literatura, uma vez que espera-se um aumento na frequéncia dos alelos favoráveis para um grande número de locos, na medida em que se pratica o melhoramento das populaçoses.

FERNANDES (1990) demonstrou que a alteração ocorrida na depressão por endogamia, após a realização de um ciclo seletivo, é fumçåo da diferença entre o progresso esperado na populaçă sob seleça e o progresso esperado nas linhagens dela originadas, obtendo, para vários esquemas de seleção recarrente, expressoles que 
possibilitaram a comparaçån entre or métodos. De maneira geral, concluiu-se que tanto para a seleçåo intra como para a interpopulacional, a depressão por endogamia aumenta em populaçðes com baixas frequências dos alelos favoráveis $(<0,5)$, praticamente não se altera com frequências alélicas intermetianias, e diminui em populaçðes com altas frequências dos alelos favoráveis (> 0,5), confinmando exatamente os mesmos pactróes observados por SOUZA JR. (1985). Foi evidenciado ainda, que dentro desta tendência geral esperada, os diferentes esquemas de seleção recorrente podem alterar a depressão por endogamia em diferentes intensidades.

No que concerne aos efeitos da seleçăo recorrente sobre a variabilidade genética, parece existir um consenso na literatura de que as alterações verificadas neste componente não tem sido suficientes para limitar o progresso com a seleçăo no longo prazo. Neste contexto, algums trabalhos mostram que a variancia genética aditiva das populaçđ̃es sob melhoramento tende a se rechurir após o primeiro ciclo de seleçåo, permanecendo em seguida relativamente constante e em niveis satisfatórios para a continuidade do processo seletivo (WEBEL \& LONQUIST, 1967; COMPION \& BAHADUR, 1977; COORS, 1988).

RAMALHO (1977) tamberm observou este padråo de comportamento em populaçōes de milho submetidas à seleção recarente intrapopulacional para a produçåa de gråos no Departamento de Genética da Escola Superior de Agricultura "Luiz de Queiroz" (ESALQ/USP), em Piracicaba, SP. Segundo este autor, WEBEL \& LONQUIST (1967) e PATERNIANI (1968) apontam como causa provável deste fato, a utilizaçåo, no primeiro ciclo seletivo, do máximo da variabilidade genética livre existente na populaçăo, correspondente a segregaçăo entre blocos poligênicos. Do primeiro ciclo em diante, 
utiliza-se, em grande parte, a variabilidade genética latente, presente dentro de blocos poligênicos e que é gradativamente liberada pela permuta genética.

HALLAUER \& MIRANDA FILHO (1981) semiram dados de dez estudos envolvendo nove populaçaes de milho submetidas a diferentes métodos e número de ciclos de seleção recmente intra e interpopulacional para a prochuçăo de gräos. Foi observado que, de maneira geral, as estimativas da variância genética aditiva foram altas nos dois ciclos seletivos iniciais, menores entre os ciclos 2 e 4, e novamente altas nos ciclos subsequentes. Portanto, năo houve evidência de que as alteraçoes ocorridas nas frequências alélicas tenham sido suficientes para recuziri de maneira significativa a variabilidade genética das populaçảes para a proctuçăo de gråos. Foram citadas como possiveis causas da tendência de reduçăo na magnitude das estimativas da variancia genética aditiva entre os ciclos 2 e 4, condiçōes ambientais desfavoráveis (estresse hidrico) e alteraçð̃es no método de colheita dos experimentos, ocorridas no perdodo correspondente.

Entre os materiais considerados no levantamento de HALLAUER \& MIRANDA FILHO (1981), encontra-se a populaçă "BSSS”, avaliada após sete ciclos de seleçåo recorrente intrapopulacional com progênies de meios inmåos, seguidos de dois ciclos com progênies $S_{2}$. Este germoplasma tem sido submetido a diferentes métodos de seleçåo recorrente desde a década de 30 e, consequentemente, é bastante utilizado em estudos de genética quantitativa aplicada ao melhoramento do milho. Em avaliaçåo feita por STUCKER \& HALLAUER (1992), onde a populaçåo "BSSS" apresentava ntvel de melhoramento semelhante ao considerado por HALLAUER \& MIRANDA FILHO (1981), também não foram observadas roduçס̨es significativas na magnitude das 
estimativas da variância aditiva e da herdabilidade para a produçăo de grãos e diâmetro de espigas, indicando, para estes caracteres, que a variabilidade genética foi liberada nas mesmas proporf̧ðెes até o ciclo mais avançado.

HOUTHAUS \& LAMKEY (1995) estudaram o compurtamento da populaçåo "BSSS" submetida a três situraçđes distintas: sete ciclos de seleção recourente intrapopulacional com progênies de meios irmåos; sete ciclos de seleção recorrente intrapopulacional com progênies de meios irmăos, seguidos de seis ciclos com progênies $\mathrm{S}_{2}$; onze ciclos de seleçăo recorrente reciproca com a populaçă "BSCB1" como testadara. Em todos os casos os valores da variância aditiva e da herdabilidade para o carater procuçăo de gräos, entre outros, permaneceram relativamente inalterados, indicando a possibilidade de sucesso futuro com a seleção pela utilizaçåo de qualquer dos métodos.

Já SCHNICKER \& LAMKKEY (1993) procuraram detectar alteraf̧es na variabilidade genética do hibrido interpopulacional "BSSS" $x$ "BSCB1", também após 11 ciclos de seleçăo recorrente reciproca para a produça de grảos. Foi observado que o hibrido de ciclo 11 năo apresentou diferenças significativas em relaçăo ao cozzamento original, no que se refere às estimativas da vanaancia genética e da herdabilidade, bem como quanto à distribuiçăo de frequência dos dados. Parece, do exposto, que o efeito da seleçăo recorrente năo atuou de maneira expressiva sobre os padrues de variaça dos materiais. Resultados semelhantes foram reportados por HALLAUER (1984), pela avaliação do hibrido interpopulacional "BSSS" $x$ "BSCB1", após sete ciclos de seleção recorremte intrapopulacional com progênies de irmåos germanos. 
No contexto ora abordado, deve-se mencionar ainda o expenimento iniciado em 1896 com a variedade "Burr's White", envolvendo seleçăo divergente para o teor de óleo e proteina no milho. Em estudo conduzido por DUDLEY \& LAMBERT (1992) após 90 geraçð̄es de seleção, ainda foi evidencisda a presença de variabilidade genética significativa no material. 


\subsection{Bases tebricas da oscilação genética}

E de conhecimento geral que em populaça infinitamente grandes, que se reprodizem completamente ao acaso, as frequências alélicas e genotipicas se mantêm constantes de geraçăo para geraçăo. Esse fenômeno, conhecido como "Equilibrio de Hardy - Weinberg" é bem explicado por diversos autores (METTLER \& GREGG, 1969; CROW \& KIMURA, 1970; FALCONER, 1989). Contudo, na natureza toda populaçă é uma entidade finita, por maior que seja. Além disso, a manurtençăo de coleçles de germoplasma e a vtilizaçåo das mesmas para fins científicos envolvem a manipulaça de populaçbes relativamente pequenas. Nestes casos, a estabilidade das froquencias alélicas ao longo das geraf̧őes pode não se venificar, pois estas frequências estão sujeitas à flutuaçōes aleatorias, que surgem em decurência da amostragem de gametas.

Os gametas que transmitem os alelos para a geraçăo seguinte, carrezam somente uma amostra do genoma dos genitores, e se esta amostra nåo é representativa da população, as frequências alélicas ficam sujeitas à alteraçőes de uma geraçăo para outra. Essa mudança aleatónia nas frequências alélicas, devido ao tamanho recurido da população, e portanto, da amostragem de gametas, é denominada "Oscilaçăo Genética" (FALCONER, 1989).

As alterą̧ōes nas frequências alélicas resultantes da amostragem são aleatónias no sentido de que sua direçăo não pode ser prevista. No entanto, sua magnitude pode ser predita em termos da variância da mudança. Considere-se a retirada de uma série de amostras (sub-populaçőes) de una populaçăo base, onde os dois alelos de um loco qualquer apresentam frequências p e q, sendo cada amostra formada por $\mathrm{N}$ indivituos e, 
comsegrentemente, por $2 \mathrm{~N}$ alelos, retirados ao acaso da populaf̧a base. As frequências alélicas destas amostras terăo, em conjumto, um valor médio igual ao encuntrado na populaçåo base ( $p$ ) e estaråo distribuldas em torno dessa média, com vaniancia $p q / 2 N$. Portanto, a magnitude da oscilaçăo genética, ou seja, da mudança na frequência alélica (סp) resultante da amostragem em uma geraça, pode ser expressa em termos de sua variancia, do seguinte modo (FALCONER, 1989):

$$
\sigma_{8 p}^{2}=\frac{p q}{2 N}
$$

Essa variância expressa a mudança esperada em qualquer amostra, ou a variância da frequência alélica que seria encontrada entre muitas amostras depois de uma geração. Isso significa, em outras palavras, que as sub-populaçores tornam-se diferentes em frequéncia alélica, embora a média, na populaçåo como um todo, permaneça intacta.

Na geraçåo seguinte, o processo de amostragem é repetido, mas cada amostra, agora, parte de uma frequência alélica diferente, e a segumda amostragem conduz a uma dispersåo adicional. A vaniancia da mudanço difere, agora, entre as amostras, visto que ela depende da frequéncis alélica $p_{1}$ de cads uma, separadamente. $O$ efeito da amostragem continuada, por meio de geraçoles sucessivas, faz com que cada sub-população flutue irrgularmente em frequência alélica, tomando-se progressivamente diferenciada das demais, o que caracteriza a oscilaçăo genética (WRIGHT, 1931).

Na medida em que este processo dispersivo ocorre, a variancia da frequência alélica entre as amostras aumenta (CROW, 1954). Contudo, existem limites para a diferenciaçăo 
entre as amostras. A frequéncia alélica nåo pode ser mudada além dos limites 0 ou 1 e, mais cedo ou mais tarde, cada amostra irá atingir um desses valores. Estes limites são pontos sem retomo pois, desde que a frequência alélica atinja o valor 0 ou 1 , ela năo poderá mais mudar nessa sub-populaçăo. Quando um alelo particular atinge a frequéncia 1, diz-se que ele foi fixado, e quando atinge a frequência 0, que foi pendido (FALCONER, 1989). No caso da fixaçăo de um determinado alelo, nenhum outro pode estar presente na amostra em questão, pois todos os seus individuos possuirăo genótipos idênticos com relaça aquele loco. Eventualmente, todas as amostras e todos os locos em uma amastra tomam-se fixados, o que se traduz na base da unifomidade genética de populaçäes altamente endogâmicas.

A oscilaçăo genética acarreta também mudanças nas frequências genotipicas. Assim, em populaçoes pequenas, elas seguem as atteraçoes nas frequéncias alélicas resultantes da amostragem. Porém, a diferenciação não é o úmico aspecto da mudança, pois a direção geral da alteração é para um aumento na frequéncia de genótipos homozigóticos e para um decréscimo na frequênciade de heterozigóticos. A razåo disso é a dispersa das frequências alélicas, afastando-se dos valores imtermediários, em direçăo aos extremos, uma vez que os heterozigotos săo mais frequentes quando as frequências alélicas são intermediárias (FAlCONER, 1989).

\subsubsection{Endogamia}

As consideraçöes feitas aqui, sobro as frequências genotipicas, descrevem a situaçăo em termos de um loco em varias amostras. As mesmas inferências podem ser 
feitas considerando-se vários locos em uma úmica amostra. Assim, o que ocorre é um incremento no número de locos para os quais os individuos são homozigotos, e um decréscimo correspondente no número de locos para os quais eles são heterozigotos. Esse fato reflete a base genética do fenômeno da endogamia, que se torna, portanto, relacionada à oscilaçåo genética em populaçőes pequenas (CROW \& KMMRA, 1970; FALCONER, 1989).

Por endogamia entende-se o acasalamento entre individuos aparentados, inclusive autofecundaçăo. Por seu turno, o grau de parentesco entre os individuos está relacionado d presença de um ancestral comum em alguma geraçåo anterior. Se todos os individuos de uma geraçåo qualquer possurssem ancestrais separados, o número destes ultrapassaria os limites de uma populaçåo real. Portanto, qualquer par de individuos deve estar relacionado com um ou mais ancestrais comuns num passado mais ou menos remoto, e quanto menor o tamanho da populaçåo, em geraçőes anteriores, maior a probabilidade de ocorrência de ancestrais comuns (FALCONER, 1989).

A principal consequência resultante do fato de dois individuos possuirem um ancestral comum é que eles podem carregar réplicas de um dos alelos presentes no ancestral, e se eles se acasalam, podem transmitir essas réplicas à sua progenie. Portanto, individuos endogâmicos podem carregar, em um loco, dois alelos que são réplicas de um mesmo alelo de alguma geraçåo anterior. Este tipo de identidade proporciona uma base para mensuração da oscilaçăo genética, mediante o grau de parentesco entre os pares acasalados.

A modida é o "coeficiente de endogamia", ou seja, a probabilidade de dois alelos em qualquer loco, num individuo, serem idênticos por descendência, refletindo o grau de 
parentesco entre os genitores desse individuo. O coeficiente de endogamia, geralmente expresso por F, foi primeiramente definido por WRIGHT (1922), como sendo a correlaçăo entre os gametas que se umem. Posteriomente, MALECOT (1948) e CROW (1954) propuseram a definição aqui apresentada, que é equivalente.

Deve-se mencionar que este conceito sommente é válido quando existe especificaçå de algum ponto no passado, no qual todos os alelos presentes na população são considerados independentes, ou seja, nåo idênticos por descendencia. Este ponto representa a populaçăo base, e, por definiçåo, tem um coeficiente de endogamia igual a zero. Em determinada geraçăo subsequente, o coeficiente de endogamia expressa a magnitude total do processo dispersivo que vem ocorrendo, desde a populaçåo base.

Para se decturir o coeficiente de endogamia em geraçoes sucessivas, parte-se da populaçå base (geraçåo 0) e de sua progênie (geraçåo 1). Existem N individuos, cada um produzindo igual número de gametas, que se unem ao acaso. Considerando-se apenas um loco, existem $2 \mathrm{~N}$ tipos diferentes de gametas, igualmente frequentes, produridos pela populaçåo base. Sendo assim, a probabilidade de um par de gametas tomados ao acaso, carregar alelos idênticos, ou seja, o coeficiente de endogamia da geraçăo 1 , é (1/2N). Na geraçăo 2, a probabilidade de alelos identicos da geraçåo 1 se umirm num zigoto é novamente $(1 / 2 N)$. Contudo, a proporf̧o remanescente de zigotos $[1-(1 / 2 N)]$ pode conter alelos idênticos em sua origem na geraçåo 0 e, portanto, a probabilidade total de se furmarem homozigotos idénticos na geraçăo 2 e:

$$
F_{2}=\frac{1}{2 N}+\left(1-\frac{1}{2 N}\right) F_{1}
$$


onde $F_{1}$ e $F_{2}$ são os coeficientes de endogamia das geraçőes 1 e 2, respectivamente. $O$ mesmo argunnento se aplica ds geraçōes subsequentes e então, de maneira geral, o coeficiente de endogamia na geraça to (FALCONER, 1989):

$$
F_{t}=\frac{1}{2 N}+\left(1-\frac{1}{2 N}\right) F_{t-1}
$$

Observa-se então, que o coeficiente de endogamia é composto de duas partes: um incremento, 1/2N, atribuido a nova endogamia, e uma parte restante, atriburda a endogamia pré-existente, Tepresentada pelo coeficiente de endogamia da geraçăo anterior.

Seria interessante neste ponto, introduzir o conceito de depressåo endogámica. Como comentado anteriormente, o acasalamento entre individuos aparentados provoca aumento da homozigose e decréscimo da heterozigose na descendéncia. Esses fatos permitem que alelos recessivos de efeito desfavorável, encobertos pelos respectivos dominantes na antiga condiçăo de heterozigose, se mamifestem em homozigose, causando uma reduçăo no valor adaptativo do individuo, denominada "depressåo ou perda de vigor por endogamia". A quantidade ou número desses alelos desfavoráveis é chamada "carga genética". Portanto, quanto maior a carga genética, maior a depressa por endogamia (VENCOVSKY \& BARRIGA, 1992). Deve-se mencionar, contudo, que a rectufăo na heterozigose, por si só, também leva a depressão por endogamia, em fumçảo da perda de interaçð̃eo alélicas favoraveis (dominância e/ou sobredominância), independentemente da presença de "carga genética" (HALLAUER \& MIRANDA FILHO, 1981). 
Outro conceito a ser introduzido é o de tamanho efetivo populacional. Como mencionado no inicio dessa abordagem, os programas de melharamento utilizam populaçð̌es relativamente pequenas, que săo submetidas à seleçăo. $O$ objetivo, na maioria dos casos, é o de aumentar a frequência dos alelos favoráveis nestas populaçđes. Porém a oscilação genética sempre atus em maior ou menor grau, fazendo com que o alelo favorável possa vir a ser perdido no decorrer dos ciclos seletivos.

A probabilidade de se fixar ou de se perder um alelo sempre depende do tamanho $\mathrm{N}$ da populaçăo. Na pratica, contudo, o que vale é o "tamanho efetivo populaciona", $N_{c}$ ou seja, o número de individuos geneticamente distintos e que efetivamente contribuem com gametas para prodıxir a geração seguinte. Em outras palavras, o número de individuos que se reproduzem com eficiência em uma populaçăo qualquer é diferente do número de individuos fisicamente presentes nesta populaçă. Do ponto de vista de melhoramento esse número varia de acordo com a estrutura da populaçăo em questáo. Exemplificando, o tamanho efetivo de uma progênie $S_{1}$ é $N_{e}=1$, pois somente um individuo contribuiu com gametas para a sua geraçăo. Analogamente, para uma progênie de inmãos germanos $N_{e}=2$, e para uma progênie de meios irmåos $N_{e} \cong 4$ (VENCOVSKY, 1987).

Do exposto, as equaçðes ( I ) e ( III) podem ser reescritas da seguinte maneira, respectivamente (FALCONER, 1989):

$$
\sigma_{\delta p}^{2}=\frac{p q}{2 N_{\varepsilon}}
$$

e, 


$$
F_{t}=\frac{1}{2 N_{e}}+\left(1-\frac{1}{2 N_{e}}\right) F_{t-1}
$$

onde fica evidente que as magnitudes da oscilaçăo genética e do coeficiente de endogamia săo inversamente proporcionais ao tamanho efetivo populacional $\left(\mathbb{N}_{e}\right)$. Em outras palavras, quanto maior o $\mathrm{N}_{e}$, maior é a probabilidade das frequências alelicas da amostra estarem próximas das frequências da população oniginal, e menor é a sua endogamia. Portanto, deve-se manter tamanhos efetivos elevados para evitar uma perda aleatória de alelos favoraveis, ou uma fixaçăo de alelos desfavoraveis, o que levaria à depressâo por endogamia, como funçăo da oscilaçăo genética (VENCOVSKY, 1987; PEREIRA \& VENCOVSKY, 1988).

\subsubsection{Médias e variâncias genéticas}

Os efeitos da oscilação genética podem ainda ser avaliados, do ponto de vista teórico, sobre as médias e vaniancias de amostras retiradas ao acaso de uma populaçăo. Considerando apenas um loco com dois alelos, a metia de uma amostra pode ser assim descrita (FALCONER, 1989; SOUZA JR., 1995):

$$
\mu_{1}=\mu-2\left(\sigma_{\varepsilon_{p}}^{2}\right) d
$$

ou

$$
\mu_{1}=\mu-2 \mathrm{pqd} / 2 \mathrm{~N}_{\varepsilon}
$$


onde $\mu_{1}$ e $\mu$ carrespondem às medias da amostra e da população ciriginal, respectivamente, e d equivale ao valor genotipico do heterosigoto. Nota-se, por essa expressão, que a média da amostra é igual a média da populaçăo criginal, menos o dobro do efeito da oscilaçāo genética ponderado pelo grau de dominância. Portanto, os efeitos da oscilaçăo genética serăo mais prommciados para caracteres com maior grau de dominância e, no caso de auséncia desta $(d=0), \mu_{1}=\mu$ para qualquer nivel de oscilação ocorrido. Observa-se ainda, que a alteraçăo na média da amostra depende também do tamanho efetivo populacional. Evidentemente, quanto maior o $\mathrm{N}_{e}$, menor a alteraça na media $\mu_{1}$ e vice-versa.

A expressão da média da amostra pode também ser expressa em fumçăo da depressåo por endogamia total do carater (DE), uma vez que, de acordo com FALCONER (1989), $\mathrm{DE}=2 \mathrm{pqd}$. Neste contexto, tem-se:

$$
\mu_{1}=\mu-\mathrm{DE} / 2 \mathrm{~N}_{\mathrm{e}} \quad \text { ( VIII) }
$$

Já os efeitos da oscilaçåo genética sobre a variância de uma amostra, são descritos separadamente para os cmmpomentes aditivo $\left(\sigma_{A}^{2}\right)$ e dominante $\left(\sigma_{D}^{2}\right)$ da variancia genética populacional, apos $t$ gerações de amostragem, da seguinte maneira, respectivamente (CROW \& KIMURA, 1970; FALCONER, 1989; SOUZA JR., 1995):

$$
\sigma_{\mathrm{A} t}^{2}=\sigma_{\mathrm{A}}^{2}\left[1-(1 / 2) \mathrm{N}_{\mathrm{e}}\right]^{t}
$$




$$
\sigma_{D t}^{2}=\sigma_{D}^{2}\left[1-(1 / 2) N_{e}\right]^{2 t}
$$

Nestas expressōes $\sigma_{A t}^{2}$ e $\sigma_{D t}^{2}$ currespondem às variâncias aditiva e dominante da t-ésima geraçăo de amostragem, respectivamente. Nota-se que os componentes da varância genética são afetados pela ocorrência da oscilaçăo genética, sendo reduridos com o deconter das geraçōes. Fica evidente que quanto menor o tamanbo efetivo da amostra, maior seré a rełuçăo nas magnitudes destes componentes. Contudo, essa reduçăo se dá em proporçð̃es diferentes, sendo mais acentuada na variancia dominante, una vez que a fraçăo redutora [ $1-(1 / 2 \mathrm{Ne})]$ é elevada a $2 t$ neste commontente e elevada a t na variância aditiva. Deve-se mencionar, tambem, que a alteraçăo nestes parametros é independente do grau de dominância dos caracteres, ao contrário do que ocorre com a média, sendo funçăo apenas do tamanho efetivo da amostra e do nummero de geraç̋̄es de amostragem.

De forma geral, verifica-se que os efeitos da oscilaçăo genética são cumulativos e se acentuam com o decorrer das geraf̧os, principalmente pela utilização de tamanhos efetivos reduridos. 


\subsection{Efeitos da seleção e da oscilaçảo genética em milho}

Para que os objetivos do melharamento via seleçåo recorremte possam ser alcançados, deve-se trabalhar com tamanhos efetivos populacionais suficientemente grandes (PEREIRA \& VENCOVSRY, 1988), o que muitas vezes não acontece em fumçåo das fortes intensidades de seleçåo aplicadas durante as geraçäes de melhoramento. Como consequência, alteraçőes na depressão por endogamia, heterose e variabilidade genética devem ocontr pela fivação ou perda de alelos por oscilaçåo genética. (WRICKE \& WEBER, 1986).

Os primeiros estudos realizados para se avaliar os efeitos da seleçåo recorrente em milho datam da década de 40, e consistiram em se fazer a regressão das médias das populaçoes selecionadas sobre os ciclos seletivos (SPRAGUE \& EBERHART, 1977). Esta metologia permitiu estimar alteraçőes da média populacional ao longo do processo seletivo, mas năo forneceu informaçőes diretas sobre as alteraçōes ocorridas nas frequências alélicas.

Posteriormente, HAMMOND E GARDNER (1974) propuseram uma modificaçăo dos cruzamentos dialélicos de GARDNER E EBERHART (1966), visando avaliar o progresso com a seleçåo recomente. A metodologia proposta permitiu estimar mudanças nas frequéncias alélicas e também o tipo de efeito alélico predominante, sendo a contribuiçăa dos locos em homozigose e heterozigose expressa como uma funçăo polinomial dos ciclos de seleçåo. Contudo, nåo foram consideradas, neste modelo, alteraçơes nas frequências alélicas ocoridas em funçăo da oscilação genética. 
Reconhecendo que, ao longo do processo de seleçåo recontente, os efeitos da depressão por endogamia devidos à oscilaçăo genética ficam confundidos com os efeitos do aumento na frequência de alelos favoráveis via seleçåo, SMITH $(1979 a, b, 1983)$ proposs um novo modelo para obter a separaçăo destas informaçðes. Este modelo pode ser descrito da seguinte maneira:

$$
\begin{aligned}
& \mathrm{C}_{(\mathrm{I} \times \mathrm{TJ})}=1 / 2(\mathrm{AOI}+\mathrm{AOI})+\mathrm{ALI}\left(\mathrm{J}^{\prime}\right)+\mathrm{ALI}^{\prime}\left({ }^{\prime}\right)+\mathrm{DOI}+\mathrm{DOI}+\theta \mathrm{HII}^{\prime}+\mathrm{DLI}(\mathrm{J})+ \\
& \operatorname{DLI}^{\prime}\left(\mathrm{J}^{\prime}\right)+(1-\theta) D Q I\left(J^{\prime}\right)+(1-\theta) D Q I^{\prime}\left(J^{\prime} J\right)+2 \theta D L \Pi^{\prime}(J)+2 \theta D L I^{\prime} I\left(J^{\prime}\right)+
\end{aligned}
$$

onde:

$\mathrm{C}_{(1 \mathrm{x} \times \mathrm{TJ})}$ é a média do crzamento entre a populaça I no ciclo seletivo $\mathrm{J}$ e a populaça I'no ciclo seletivo J';

$\theta$ é um fator condicionante tal que $\theta=1$ para $I \neq \Gamma$ e $\theta=0$ para $I=I^{\prime}$;

AOI e AOI' carrespondem à contribuição dos locos em homozigose ou dos efeitos aditivos para o ciclo 0 das populaçöes I e I', respectivamente;

DOI e DOI' conrespondem à contribuição dos locos em heteroxigose ou dos efeitos de dominância para o ciclo 0 das populaçð̌es I e I', respectivamente;

ALI e ALI' săo fumçð̄es lineares das alteraç̋̄es nos locos em homozigose ou contribuição dos efeitos aditivos para o progresso com a seleção nas populaçð̄es I e I', respectivamente; 
DLI e DLI' são fimç̄es lineares das alteraçđes nos locos em heteroxigose ou contribuição dos efeitos de dominância para o progresso com a seloçåo nas populações I e I', respectivamente;

HII' é a heterose no cnzamento do ciclo 0 da populaça I com o ciclo 0 da populaçåo I';

DQI e DQI' são funf̧̋̉es quadraticas das alteraçðes nos locos em heterozigose das populaçð̃es I e I', respectivamente. Conrespondem ao efeito da oscilação genética nestas populaçð̄es, pelo uso de tamanhos efetivos populacionais recturidos ( $\mathrm{Ne}<25)$;

DLII' e DLI'I são funçỏes lineares das alteraf̧̃̃es nos locos em heterozigose ou contribuição dos efeitos de dominância das populaçōes I e I', respectivamente, para o progresso com a seleção no cruzamento entre elas;

HQII' é uma fumçăo quadratica das alteraçðes nos locos em heterozigose no cruzamento da poprulaçă I com a população I'.

O modelo geral pode ainda ser estendido à primeira geraçăło de autofecundação dos materiais $\left(S_{1}\right)$. Neste caso, de acordo com SMITH (1983), tem-se:

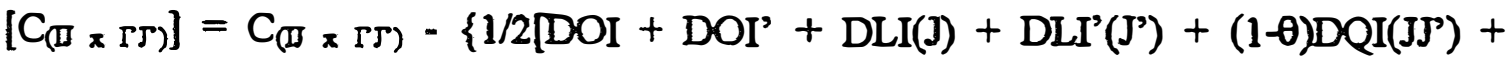

$$
\begin{aligned}
& \left.\left.(1-\theta) D Q I^{\prime}\left(J^{\prime} J\right)\right]+\theta H I \Gamma+\theta D L \Pi^{\prime}(J)+\theta D L I^{\prime} I\left(J^{\prime}\right)+\theta H Q \Pi^{\prime}\left(J J^{\prime}\right)\right\} ;
\end{aligned}
$$


Observa-se que para se estimar todos os parimetros do modelo, necessário se faz trabalhar com um grande numero de equaçőes, o que se consegue pela obtençåo de materiais derivados das populaçōes I no ciclo J e I' no ciclo J', através de cruzamentos dialélicos e autofecumdaçðes.

A partir de então, vários trabalhos foram realizados visando quantificar os efeitos das alteraçóes nas frequências alélicas decarsentes da seleção e da oscilação genética, em populaçðes de milho submetidas a diferentes métodos de seleção recontente. Os principais resultados destes estudos são descritos a seguir.

SMITH (1979b) empregou sua metodologia para comparar os efeitos da seleça recorrente intrapopulacional na produtividade da populaçåo de millo "BSK", pela utilização de progênies de meios immåos e de progênies $S_{1}$, apos quatro ciclo seletivos. Verificou-se que ambos os métodos faram eficientes em aumentar a frequéncia de alelos favoráveis de efeito aditivo, e que os efeitos da depressăo por endogamia causada pela oscilaçăo genética se mostraram altamente significativos, sendo acumulados em proporçőes semelhantes nos dois casos, suprimindo grande parte do progresso esperado com a seleçåo.

O mesmo autor (SMTTH, 1983), procurrou quantificar os efeitos da seleçăo e da oscilaçåo genética em duas populações de milho, "BSSS" e "BSCB1", avaliadas quanto a produçåo de gråos após oito ciclos de seleçåo reconente recíproca. A contribuiçăo dos efeitos de dominancia (DLI) para o progresso com a seleção se mostrou marcamte, apesar da oconéncia de alterações significativas também nos locos em homozigoze (ALI). $O$ parâmetro DQI, relativo ao efeito da oscilaçăo genética, se mostrou significativo para os dois materiais, o que se confirmou pela ausência de resposta à seleça nas populaçס̃es per 
se (resposta indireta). Estudos realizados por HELMS et al. (1989) e KEERATINIJAKAL \& LAMKEY (1993), com as mesmas populaçðes, apos 10 e 11 ciclos de seleçåo recorrente reciproca, respectivamente, confirmam estes resultados.

Ainda neste estudo (SMITH, 1983), a populaçă "BSSS" foi avaliada após sete ciclos de seleção recortente intrapopulacional com progênies de meios immåos. Também neste caso, houve contribuiçăo significativa dos efeitos aditivos (AII) e de dominância (DLI) para o progresso com a seleçăo. O efeito da oscilaçåo (DQ1) tamberm foi significativo e limitou este progresso, mas sua magnitude foi bem inferior às abservadas nas populaçães sob seleçåo recomente rectproca. Apesar disso, outros estudos realizados com os mesmos materiais evidenciam resultados contráios, ou seja, a ocontencia de efeitos significativos da oscilaçåo genética afetando de maneira semelhante o desempenho das populaçães per se obtidas via seleçåo recorrente reclpraca e via seleçăo recurente intrapopulacional (OYERVIDES-GARCIA \& HALLAUER, 1986; HELMS et al., 1989).

Outro trabalho a ser mencionado foi realizado por TRAGESSER et al. (1989), relativo a cinco ciclos de seleção recorrente intrapopulacional com progênies $S_{1}$, aplicados sobre as populaçoes de milho "NBS", "NSS" e "NKS". Estas populaçoes tamberm foram submetidas a cinco ciclos de seleçåo recarrente reciproca, formando pares entre si. A avaliação para o carater produçăa de gråos mastrou que, independemte do mótodo utilizado, algumas pupulaçðe nao apresentaram alteraçðes significativas quanto à contribuiçåo conjunta dos efeitos aditivos e de dominancia (ALI e DLI). Por outro lado, em todos os casos (populações e métodos) houve significância do parâmetro DQI, fazendo com que o progresso nas populaçea per se não refletisse a resposta potencial destes materiais à seleção. 
Já no trabalho realizado por EYHERABIDE \& HALLAUER (1991), foram avaliados os efeitos genéticos acumulados nas populações de milho "BS10" e "BS11", submetidas a oito ciclos de seleção recorrente reciproca com progênies de irmåos germanos. Foi detectada alteraf̧ão significativa na contribuição dos efeitos aditivos (AL), no sentido de aumentar a produtividade, o indice de prolificidade e a altura das espigas na populaçă "BS11", o que não se verificou para a populaçåo "BS10". Alteraçð̃es significativas nos locos em heterozigose, ou na contribuição dos efeitos de dominancia (DLI), foram observadas no sentido de rechuzir a expressão dos caracteres indice de prolificidade e altura da planta na população "BS11", e no sentido de aumentar a prođutividade na populaçăo "BS10", evidenciando tendências opostas para os dois materiais. No que se refere aos efeitos da oscilação genética (DQ1), ambas as populaçōes foram significativamente desearacterizadas no seu comportamento per se, para o caráter produção de gräos, de modo que, se descontado este efeito negativo de DQI, a resposta indireta à seleção năo apresentaria diferenças marcantes em relaçăo a resposta direta no híbrido interpopulacional.

Merece mença também, o estudo conduzido por LANDI \& FRASCAROLI (1993), onde foram avaliados quatro ciclos de seleçåo recourente intrapopulacional com progênies de irmåns germanos em uma população $F_{2}$ de milho. Foi observado aumento significativo na frequência de alelos de efeito aditivo (ALI), contribuindo para aumentar a produção de grăos, a altura da planta e a altura da espiga. Tambem neste caso houve significancia dos efeitos da oscilaçăo genética, atuando em sentido contrário aos efeitos da seleçăo, ou seja, contribuindo para reduzir a produçăo de grĕos e a altura da planta e da espiga. Verificou-se que, apesar da resposta direta d̀ seleça ter sido expressiva após 
quatro ciclos seletivos, esta não foi suficiente para compensar os efeitos negativos da reduçăo na heterocigose provacads pela oscilaçăo genética, pois o hibrido $F_{1}$ foi significativamente mais produtivo que a populaçăo melhorada por quatro geraçð̄es.

Ainda neste contexto, STOJ $\breve{~ I N ~ \& ~ K A N N E N B E R G ~(1994) ~ p r o c u m a r a m ~ q u a n t i f i c a r ~}$ os efeitos da oscilaçăo genética na produção de gràos de cinco populaçð̃ea de milho submetidas a diferentes métodos de seleçâ recontente intrapopulacional (espiga por fileira, meios irms̊os, $S_{1}$ e $S_{2}$ ), sendo duas delas tamberm submetidas à seleçăo recomente reciproca. A resposta à seleçăo foi atingida em funçăo de alterações significativas nas frequências de alelos de efeito aditivo (ALI) e/ou dominante (DL), observando-se para os métodos que se valeram de progênies endogâmicas $S_{1}$ e $S_{2}$, maior contribuição dos efeitos aditivos. Apesar de o nimero de ciclos seletivos observado em cada situagão ter sido variável, na maioria dos casos, foram detectados efeitos significativos da oscilaçăo genética, atuando em sentido oposto ao do progresso com a seleçăo para a produçăo de gråos. Verificou-se ainda, que estes efeitos foram mais pronunciados quando se utilizou a seleçăo ronorrente intrapopulacional com progênies endogâmicas $\left(S_{1}\right.$ e $\left.S_{2}\right)$, e menos pronunciados com a ưilização do mesmo procedimento, com progênies de meios imãos.

Deve-se salientar que, de maneira geral, nos estudos ora mencionados tem sido observada contribuiçăo significativa dos efeitos aditivos e de dominåncia nas populą̧ð̌es originais (AOI e DOI, respectivamente). A magnitude destes efeitos tem sido bastante variável nos diferentes estudos, não existindo uma tendencia de predominância de algum tipo, aditivo ou dominante. Informaçð̃es importantes sobre a contribuiçåo dos materiais para a heterose de cruzamentos tambem tem sido obtidas, observando-se, em grande parte 
dos estudos, a não significância do parâmetro HQII', ou seja, a ausência de atteração dos efeitos de dominalncia no hibrido interpopulacional (SMTTH, 1983; HEIMS et al., 1989; EYHERABDE \& HALLAUER, 1991; KEERATINIJAKAL \& LAMKEY, 1993).

Ressaltese, portanto, que a metodologia de SMITH (1979a, b, 1983) tem se mostrado bastante eficiente para explicar os fenômenos ocorridos durante os processos seletivos, evidenciando a importancia da oscilaçăo genética como um fator limitante ao progresso obtido com a seleçåo nos programas de melhoramento com a cultura do milho. 


\section{MATERIAL E MÉTODOS}

\subsection{Material genético}

Foram utilizadas neste estudo duas populaçđes de milho denominadas BR-105 e BR-106, obtidas no Centro Nacional de Pesquisa de Milho e Sorgo da EMBRAPA. Estas populaçðes possuem origem e estnumuras genéticas diferentes, apresentando valores elevados de heterose em seu cruzamento (NASPOLINI FIIHO et al., 1981). A populaça BR-105 é onginária da Tailândia enquanto a BR-106 se origina de materiais do Brasil e do México. Ambas apresentam ciclo e porte intermediários, sendo que a BR-105 possui gråos semi-duros de coloraçåo alaranjada e a BR-106 possui gråos dentados de coloraçåo amarela (SOUZA JR. et al., 1993).

Foram utilizadas, também, duas variedades sintéticas denominadas IG-3 e IG-4, derivadas, respectivamente, das populaf̧̄es BR-105 e BR-106. Na obtenç̧̊o destes materiais, quatrocentas linhagens $S_{3}$ de cada populaçao foram submetidas à seleção para capacidade de combinaçăo, utilizando como testadores as populaçסes reciprocas. Esta seleção foi feita com base na avaliaçăo do caráter prođuçåo de grảos, entre outros. A seguir, as quarenta linhagens superiores, de cada populaçă, foram avaliadas quanto ao seu comportamento per se, selecionando-se oito linhagens elite da populaçă BR-105 e 
dez linhagens elite da populaçă BR-106. As oito linhagens elite da população BR-105 foram intercruzadas gerando o sintético denominado IG-3, e as dez linhagens elite da populafäo BR-106 foram inlercruzadas gerando o sintético IG-4.

Deve-se mencionar que as linhagens foram inicialmente intercnzadas em um sistema dialélico e a seguir, o material foi recumbinado por trés gerações. Portanto, para esta pesquisa, espera-se que estes sintéticos estejam próximos do equilibrio de ligacăo e em equilibrio de Hardy-Weinberg. Verifica-se ainda, que a intensidade de seleção utilizada para a formaçăo dos sintéticos IG-3 e IG-4 foi de $2,0 \%$ e $2,5 \%$, e que seus tamanhos efetivos populacionais correspondem a 4,57 e 5,71, confenindo a estes matenais coeficientes de endogamia (F) de 10,94\% e 8,75\%, respectivamente. Pode-se considerar, do exposto, que a obtenção dos sintéticos IG-3 e IG-4 é resultado de um ciclo de seleçåo recorrente reciproca, onde foram aplicadas fortes intensidades de seleçåo sobre as populaçð̃es BR-105 e BR-106.

\subsection{Tratamentos e procedimentos experimentais}

Para se investigar os efeitos da seleçåo e da oscilaçåo genética sobre componentes de médias, heterose e depressão por endogamia as populaçỏes e os sintéticos foram imtercnzzados em um sistema dialélico e, simultaneamente, autofecundados e multiplicados. Os crizamentos, os materiais autofecundados $\left(\mathrm{S}_{1}\right)$ e os materiais per se correspondem a seis, quatro e quatro entradas, respectivamente, totalizando quatorze tratamentos, aos quais foram acrescentados dois hibridos comerciais, denominados C-855 e AG-672, utilizados como testemunhas. 
Estes tratamentos foram avaliados durante o ano agricola de 1994/95, em três locais, sendo dois deles em Piracicaba-SP, denominados Areizo e Caterpillar (ESALQ/USP), e o terceiro em Andradas-MG (Sementes Agroceres S/A). Os experimentos foram instalados em blocos casualizados, com dez repetiçס̄es por local, e as parcelas foram constituddas de três linhas de quatro metros de comprimento, espacadas entre si por $90 \mathrm{~cm}$, tomando-se dados apenas da linha central. Adotou-se esta medida para evitar a ocorréncia de competiçס̋es desfavoráveis e favoráveis causadas pela depressa por endogamia e pela heterose dos cnzamentos, respectivamente. A densidade de semeadura foi de cinco plantas por metro linear, resultando numa populaçåo de 55.555 plantas / ha.

Paralelamente, procurou-se verificar os efeitos da seleçăo e da oscilaçăo genética sobre a variabilidade genética dos materiais. Para isso, foram obtidas 169 progênies de irmfos germanos interpopulacionais do cruzamento entre as populaģ̋es BR-105 e BR-106, e 169 progênies de irmåos germanos interpopulacionais do cruzamento entre os sintéticos IG-3 e IG-4. Na avaliação destas progênies foram empregados dois látices $13 \times 13$, instalados em dois campos experimentais da ESALQ/USP (Areião e Caterpillar), em Piracicaba-SP, com duas repetiçđes por local. As parcelas foram constituidas de uma única linha de quatro metros de comprimento, e foram separadas entre si por $90 \mathrm{~cm}$. A densidade de semeadura foi de cinco plantas por metro linear, obtendo-se uma populaça de 55.555 plantas / ha.

Cada látice foi formado por metade das progênies de cada cruzamento, sendo que este procedimento foi adotado para permitir a comparacăo das progênies obtidas do cruzamento BR-105 x BR106 com aquelas provenientes do cruzamento IG-3 x IG-4, no 
que diz respeito às estimativas dos componentes de variância. Assim, no ensaio denominado "experimento 1 " foram avaliadas, nos dois locais em questån, 85 progénies do crzamento BR-105 x BR-106 e 84 progênies do cruzamento IG-3 x IG-4, sendo as progênies restantes de cada cnuzamento (84 progênies do cnizamento BR-105 x BR-106 e 85 progênies do cnzamento IG-3 x IG-4) avaliadas no ensaio denominado “expenimento $2^{n}$, instalado, tambem, nos dois ambientes mencionados.

Os dados foram obtidos ao nivel de medias de parcelas para os seguintes caracteres: PE - peso de espigas despalhadas (g/planta), obtido apos pactronizaça do teor de umidade, corrigido para o estande médio do ensaio pela técnica da análise de covariância; AP - altura da planta (cm), tomada em cinco plantas competitivas dentro da parcela; $\mathrm{AE}$ altura da espiga (cm), tomada em cinco plantas competitivas dentro da parcela; r = AE/AP - relaçåo entre altura da espiga e altura da planta. Indica a posiçăo relativa da espiga na planta; NE - indice de prolificidade (espigas/planta), obtido pela relaçåo entre número total de espigas da parcela e estande final.

\subsection{Anślise estatistico-genetica dos dados}

Os resultados das avaliaçoes feitas nos experimentos realizados para verificar os efeitos da seleçăo e da oscilaçăo genética sobre componentes de médias, heteraso e dejpressão por endogamia, foram inicialmente sutumetidos à análises individuais para cada local e, a seguir, foram realizadas análises conjuntas, de acordo com o seguinte modelo matemático, considerado misto: 
$Y_{i j k}=m+t_{i}+l_{j}+t_{i j}+b_{(x)}+e_{i j k}$

onde:

$Y_{i j k}$ é a observafă relativa ao tratamento $i$, do bloco $k$ dentro do local $j$;

m é a métia geral fixa;

$t_{i}$ é o efeito do tratamento i $(i=1,2,3, \ldots, 16)$, suposto fixo;

lje é o efeito do local j $(j=1,2,3)$, suposto aleatório;

$t_{i j}$ é o efeito da imeraçăo do tratamento i com o local j, suposto aleatório;

$b_{x(0)}$ é o efeito do bloco $k(k=1,2,3, \ldots, 10)$, dentro do local $j$, suposto aleatório;

eijk é o erro experimental associado à observaçåo $Y_{i j k}$, aleatório.

A partir das medias gerais de tratamentos foram estimadas: as depressőes por endogamia totais como $\hat{\mathrm{d}}=2\left(\hat{\overline{\mathrm{S}}}_{0}-\hat{\overline{\mathrm{S}}}_{1}\right)$, e em porcentagem: $\hat{\mathrm{d}}(\%)=\left(\hat{\mathrm{d}} / \hat{\overline{\mathrm{S}}}_{0}\right) 100$, o que comesponde a contribuiçăo dos locos em heterozigose para o carater ; as heteroses como $\hat{\mathbf{h}}=\hat{\overline{\mathrm{F}}}_{1}-\left(\hat{\overline{\mathrm{P}}}_{1}+\hat{\overline{\mathrm{P}}}_{2}\right) / 2$, e em porcentagem: $\hat{\mathbf{h}}(\%)=\left\{\hat{\mathrm{h}} /\left[\left(\hat{\overline{\mathrm{P}}}_{1}+\hat{\overline{\mathrm{P}}}_{2}\right) / 2\right]\right\} 100$; e as medias esperadas de linhagens retiradas ao acaso destes materiais: $\hat{\overline{\mathrm{L}}}=2 \hat{\overline{\mathrm{S}}}_{1}-\hat{\overline{\mathrm{S}}}_{0}$ (VENCOVSKY \& BARRIGA, 1992). Nestas expressర̋es, $\bar{S}_{0}$ e $\bar{S}_{1}$ currespundem, respectivamente, à médias dos materiais per se, em parmixis e com uma geraçăo de autofecundação, e $\overline{\mathrm{F}}_{1}, \overline{\mathrm{P}}_{1}$ e $\overline{\mathrm{P}}_{2}$, respectivamente, às médias do híbrido em questăo e de cada um dos seus genitores. 
Os dados foram entalo submetidos à análise estatístico-genética de acondo com 0 modelo proposto por SMTTH (1979a, b, 1983). Para isso, foram utilizadas, tambem, as médias gerais de tratamentos, exceçåo feita às testemunbas. O modelo generalizado pode ser descrito da seguinte maneira:

$$
\begin{aligned}
& \mathrm{C}_{\left(\mathrm{I} \times \mathrm{IS}^{\prime}\right)}=1 / 2\left(\mathrm{AOI}+\mathrm{AOI^{ \prime } )}+\mathrm{ALI}(\mathrm{J})+\mathrm{ALI}^{\prime}\left(\mathrm{J}^{\prime}\right)+\mathrm{DOI}+\mathrm{DOI}+\theta \mathrm{HII}^{\prime}+\mathrm{DLI}(\mathrm{J})+\right. \\
& \operatorname{DLI}^{\prime}\left(\mathrm{J}^{\prime}\right)+(1-\theta) \mathrm{DQI}(\mathrm{JJ})+(1-\theta) \mathrm{DQI}\left(\mathrm{J}^{\prime} J\right)+2 \theta \mathrm{DLI}\left(\mathrm{J}^{\prime}\right)+2 \theta \mathrm{DLI} \mathrm{I}\left(\mathrm{J}^{\prime}\right)+ \\
& \text { 20HQII'(JJ'); }
\end{aligned}
$$

onde:

$\mathrm{C}_{(\overline{1} \times \Gamma \Gamma)}$ é a média do cruzamento entre a populaçăo I no ciclo seletivo $\mathrm{J}$ e a população I'no ciclo seletivo $\mathrm{S}$;

$\theta$ é um fator condicionante tal que $\theta=1$ para $I \neq I^{\prime}$ e $\theta=0$ para $I=T$;

$\mathrm{AOI}=\mu+\Sigma(2 \mathrm{p}-1) \mathrm{a}$, e $\mathrm{AOI}^{\prime}=\mu^{3}+\Sigma(2 \mathrm{r}-1) \mathrm{a}$, correspondem à contribuiçăo dos

locos em homozigose ou dos efeitos aditivos para o ciclo 0 das populaçðes I e I', respectivamente;

DOI $=\Sigma p(1-p) d$, e DOI' $=\Sigma r(1-r) d$, correspondem d contribuiça dos locos em heteroxigose ou dos efeitos de dominância para o ciclo 0 das populaçbes I e $I^{2}$, respectivamente;

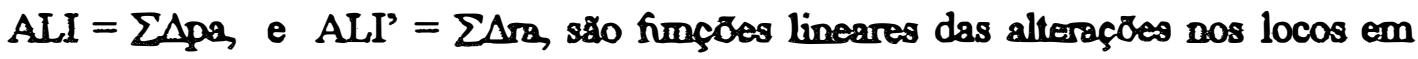
homozigose ou contribuição dos efeitos aditivos para o progresso com a seleção nas populaçoôs I e I', respectivamente; 
$D L I=\Sigma \Delta p(1-2 p) d$, e $D L I^{\prime}=\Sigma \Delta r(1-2 r) d$, são funçð̃es lineares das alteraçoes nos locos em heterozigose ou contribuição dos efeitos de dominância para o progresso com a seleçăo nas populaçdeo I e I', respectivamente;

HII' $=\Sigma(p-r)^{2} d$, é a heterose no cruzamento do ciclo 0 da populaçăo I com o ciclo 0 da populaçăo I';

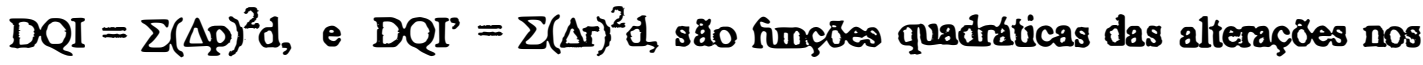
locos em heterorigose das populações I e I', respectivamente. Correspondem ao efeito da oscilaçăo genética nestas populaçőes, pelo uso de tamanhos efetivos populacionais recturidos ( $\mathrm{Ne}<25$ );

DLI' $=\Sigma \Delta p(p-r) d$, e DLI'I $=\Sigma \Delta v(r-p) d$, são fumçōes lineares das alteraçðes nos locos em heterozigose ou contribuição dos efeitos de dominância das populaçðes I e I', respeztivamente, para o progresso com a seleçăo no crizamento entre elas;

HQI" $=\Sigma \Delta p \Delta r d$, é uma funçåo quadratica das alteraçōes nos locos em heterozigose no cruzamento da população I com a populaçă I'.

Os parámetros genéticos descritos são definidos considerando-se o madelo com dois alelos por loco. Nesta notaçåo $\mu$ e $\mu^{\prime}$ carrespondem às médias dos homozigotos extremos das populaçōes I e I', respectivamente; p e r correspondem às frequências do alelo favorável nas populações I e I', respectivamente; a, d e -a săo os valores genotípicos do hamozigoto favorável, do heterozigoto e do homozigoto desfavoravel, respectivamente; 
e $\Delta p$ e $\Delta r$ são as alteraçðes nas frequências do alelo favoravel nas populaçőes I e I', respectivamente.

Deve-se mencionar que no modelo proposto por SMITH (1979a, b, 1983), o parametro relativo ao efeito da oscilaçăo genética é definido como $D Q I=\Sigma(\Delta p)^{2}$ d. Contudo, segundo FALCONER (1989), 4 representa alteraçớes nas frequências do alelo

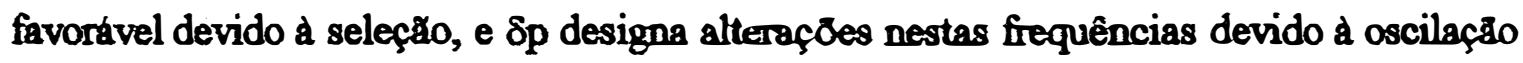
genética. Portanto, como se trata de processos distintos, deve-se considerar $\mathrm{DQI}=\Sigma(\delta \mathrm{p})^{2} \mathrm{~d}$, caracterizando este efeito como decomente da oscilaçåo genética.

O modelo geral pode ainda ser estendido à primeira geraçăo de autofecumdaço dos materiais $\left(\mathrm{S}_{1}\right)$. Neste caso, de acordo com SMITH (1983), tem-se:

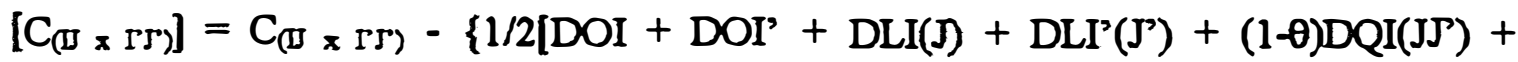

$$
\begin{aligned}
& \left.\left.(1-\theta) D Q I^{\prime}\left(J^{\prime} J\right)\right]+\theta H^{\prime}+\theta D L I^{\prime}(J)+\theta D L I^{\prime} I\left(J^{\prime}\right)+\theta H Q I^{\prime}(J 丁)\right\} ;
\end{aligned}
$$

Do exposto, os quatorze tratamentos em questăo foram expressos da seguinte maneira, considerando-se os sintéticos IG-3 e IG-4 como o resultado do $1^{\circ}$ ciclo de seleção recorrente reciproca aplicado sobre as populaçoes BR-105 e BR-106, respertivamente:

$$
\begin{aligned}
& \mathrm{BR}-105=\mathrm{C}_{(\mathrm{I} 0 \times \mathrm{I} 0)}=\mathrm{AOI}+2 \mathrm{DOI} \\
& \mathrm{BR}-106=\mathrm{C}_{(\mathrm{I} 0 \times \mathrm{I} 0)}=\mathrm{AOI}^{\prime}+2 \mathrm{DOI}^{\prime} ; \\
& \mathrm{IG}-3=\mathrm{C}_{(\mathrm{II} \times \mathrm{II})}=\mathrm{AOI}+2 \mathrm{ALI}+2 \mathrm{DOI}+2 \mathrm{DLI}+2 \mathrm{DQI} ;
\end{aligned}
$$


$\mathrm{IG}-4=\mathrm{C}_{\left(\Gamma 1 \times \Gamma I^{\prime}\right)}=\mathrm{AOI}^{\prime}+2 \mathrm{ALI}+2 \mathrm{DOI}+2 \mathrm{DLI}^{\prime}+2 \mathrm{DQI}^{\prime}$

$\mathrm{BR}-105 \mathrm{~S}_{1}=\left[\mathrm{C}_{(10 \times 10)}\right]=\mathrm{AOI}+\mathrm{DOI}$

$\mathrm{BR}-106 \mathrm{~S}_{1}=\left[\mathrm{C}_{(\mathrm{I} 0 \times \mathrm{r} \mathrm{r})}\right]=\mathrm{AOI}+\mathrm{DOI} ;$

$I G-3 S_{1}=\left[C_{(I I x I I)}\right]=A O I+2 A L I+D O I+D L I+D Q I ;$

IG-4 $S_{1}=\left[C_{(I 1 \times \Gamma 1)}\right]=$ AOI' $+2 A L I^{\prime}+D^{\prime} I^{\prime}+D^{\prime} I^{\prime}+D^{\prime} I^{\prime}$

$\mathrm{BR}-105 \times \mathrm{BR}-106=\mathrm{C}_{(10 \times \mathrm{r} 0)}=(1 / 2) \mathrm{AOI}+(1 / 2) \mathrm{AOI}^{\prime}+\mathrm{DOI}+\mathrm{DOI}^{\prime}+\mathrm{HII}{ }^{\prime} ;$

$\mathrm{BR}-105 \times \mathrm{IG}-3=\mathrm{C}_{(10 \times \mathrm{M})}=\mathrm{AOI}+\mathrm{ALI}+2 \mathrm{DOI}+\mathrm{DLI} ;$

BR-105 x IG-4 $=\mathrm{C}_{\left(10 \times \mathrm{r}^{\prime}\right)}=(1 / 2) \mathrm{AOI}+(1 / 2) \mathrm{AOI}^{\prime}+\mathrm{ALI}+\mathrm{DOI}+\mathrm{DOI}^{\prime}+\mathrm{HII}^{\prime}+$ DLI' + 2DLI'I;

$\mathrm{BR}-106 \times \mathrm{IG}-3=\mathrm{C}_{(\mathrm{I} 1 \times \mathrm{r} 0)}=(1 / 2) \mathrm{AOI}+(1 / 2) \mathrm{AOI}^{\prime}+\mathrm{ALI}+\mathrm{DOI}+\mathrm{DOI}^{\prime}+\mathrm{HII}+$ DLI + 2DLII';

BR-106 x IG-4 = $\mathrm{C}_{(\mathrm{T} 0 \times \mathrm{r} 1)} \mathrm{C}_{0} \mathrm{I}^{\prime} \times \mathrm{C}_{1} \mathrm{I}^{\prime}=\mathrm{AOI}+\mathrm{ALI}^{\prime}+2 \mathrm{DOI}+\mathrm{DLI}$;

IG-3 x IG-4 $=\mathrm{C}_{(11 \times \Gamma 1)}=(1 / 2) \mathrm{AOI}+(1 / 2) \mathrm{AOI}^{\prime}+\mathrm{ALI}+\mathrm{ALI}+\mathrm{DOI}+\mathrm{DOI}^{\prime}+\mathrm{HII}{ }^{\prime}$ + DLI + DLI' + 2DLI' + 2DLI'I + 2HQI'.

Os pardmetros genéticos do modelo foram estimados pela resolução do sistema de equaçbes anteriormento descrito. Neste procedimento foi emmsegado o método dos minimos quadrados: $\hat{\beta}=\left(X^{\prime} X\right)^{-1}\left(X^{\prime} Y\right)$, onde $\hat{\beta}$ comresponde ao vetor de parametros estimáveis do modelo, $\mathrm{Y}$ é o vetor formado pelas médias de tratamentos para o carater avaliado, e X é a matriz composta pelos coeficientes dos parametros, cuja estrutura é apresentada na Tabela 1. 
A matriz $\left(X^{\prime} X\right)$ e nåo-singular e portanto possui inversa única. Consequentemente, o sistema de equaç̋̄es lineares é consistente e determinado, apresentando soluç̧̊o também única $(\hat{\beta})$. As variâncias relacionadas a cada estimativa $[\mathrm{V}(\hat{\beta})]$ foram obtidas multiplicando-se a diagonal principal da matriz $\left(X^{\prime} X\right)^{-1}$ pela relação entre o quadrado médio do residuo da análise conjunta e o produto do número de repetições pelo número de locais utilizados nos experimentos. A partir de $V(\hat{\beta})$, foram obtidos os erros associados às estimativas $[s(\hat{\beta})]$, utilizados para verificar a significância dos parametros do modelo, através do teste $t$ para a hipótese de nulidade do parámetro, ao nivel de $5 \%$ de probabilidade. O parâmetro não significativo de menor valor absoluto de $t$ foi descartado para teste do modelo reduzido e, assim sucessivamente, até que todos os semamescentes se mostrassem significativos. Este procedimento, denominado "beckward", e descrito por DRAPER \& SMITH (1966).

No que se refere aos experimentos conduzidos para avaliar os efeitos da seleção e da oscilação genética sobre a variabilidade genética dos materiais, inicialmente foram realizadas análises de vaniancia individuais, por experimento e por local. Em seguida, foram obtidas análises conjuntas para cada experimento e, finalmente, foi realizada a análise conjunta agrupada, cuja estrutura é apresentada na Tabela 2.

Nestas análises a soma de quadrados de "progênies" foi deadobrada em soma de quadrados de progênies do cruzamento entre as populaçð̌es BR-105 e BR-106 ("progênies P") e soma de quactrados de progênies do cruzamento entre os sintéticos IG-3 e IG-4 ("progênies S"), para permitir a comuparaçăo entre os componentes de variância obtidos para os dois tipos de materiais. Procedimento análogo foi adotado para a soma de 
quadrados de "progênies x locais", no caso das análises conjuntas e da análise conjunta agrupards.

Pela manipulaçåo dos quadractros médios da análise de variância conjunta agupards (Tabela 2) foram estimados os seguintes parametros, segundo metodologia apresentada por VENCOVSKY (1987) e VENCOVSKY \& BARRIGA (1992):

$\sigma^{2}:$ variancia do erro experimental como $\hat{\sigma}^{2}=Q_{12}$;

$\sigma_{\text {gple }}^{2}:$ variancia genética das progênies do couzamento entre as populaçōes BR-105

e BR-106, dentro de experimentos, como $\hat{\sigma}_{p p / e}^{2}=\left(Q_{s}-Q_{g}\right) / r l$;

$\sigma_{\text {pele }}^{2}$ : variancia genética das progênies do cruzamento entre os sintéticos IG-3 e

IG-4, dentro de experimentos, como $\hat{\sigma}_{p s e}^{2}=\left(Q_{6}-Q_{10}\right) / r$;

$\sigma_{(p p / e) !}^{2}:$ variancia da interaç̧̊ das progênies do crzzamento BR-105 x BR-106, dentro de experimentos, com locais, como $\hat{\sigma}_{(p p / e) 1}^{2}=\left(Q_{9}-Q_{12}\right) / r$,

$\sigma_{(p a / e) 1}^{2}$ : variancia da interaçáo das progênies do cruramento IG-3 x IG-4, dentro de experimentos, com locais, como $\hat{\sigma}_{(\mathrm{ps} / \mathrm{e}) 1}^{2}=\left(\mathrm{Q}_{10}-\mathrm{Q}_{12}\right) / \mathrm{r}_{\mathrm{s}}$

$\sigma_{\mathrm{Fp} / \mathrm{e}}^{2}=\sigma^{2} / \mathrm{rl}+\sigma_{(\mathrm{pp} / \mathrm{e}) 1}^{2} \Lambda+\sigma_{\mathrm{pp} / \mathrm{e}}^{2}:$ variância fenotípica ao nivel de medias das progênies do cruzamento BR-105 x BR-106, dentro de experimentos, como $\hat{\sigma}_{\mathrm{Fp} / \mathrm{e}}^{2}=\mathrm{Q}_{\mathrm{S}} \mathrm{r} \mathbf{i}$ 
$\sigma_{\mathrm{F} / \mathrm{e}}^{2}=\sigma^{2} / \mathrm{r}+\sigma_{(\mathrm{p} / \mathrm{e}) 1}^{2} \Lambda+\sigma_{\mathrm{p} / \mathrm{e}}^{2}:$ variância fenotipica ao nivel de medias das progênies do crezamento IG-3 x IG-4, dentro de experimentos, como $\hat{\sigma}_{\mathrm{F} z l \mathrm{e}}^{2}=\mathrm{Q}_{\delta} / \mathrm{rl}$

$h_{\mathrm{p}}^{2}=\sigma_{\mathrm{pple}}^{2} / \sigma_{\mathrm{Fp} / \mathrm{e}}^{2}:$ coeficiente de herdabilidade ao nivel de médias das progenies do crozamento BR-105 x BR-106;

$h_{s}^{2}=\sigma_{p y / e}^{2} / \sigma_{F y / e}^{2}:$ coeficiente de herdabilidade ao ntvel de médias das progênies do cruzamento IG-3 x IG-4;

$\mathrm{RS}_{\mathrm{p}}=\mathrm{i} \sigma_{\mathrm{pple}}^{2} / \sigma_{\mathrm{Fp} / \mathrm{e}}:$ resposta esperada à seleção das progênies do cnzamento BR-105 x BR-106;

$\mathrm{RS}_{3}=i \sigma_{\mathrm{p} J \mathrm{e}}^{2} / \sigma_{\mathrm{Fz} / \mathrm{e}}:$ resposta esperada d̀ seleçâo das progenies do cruzamento IG-3 $\mathrm{x}$ IG-4.

Nas expressões das respostas esperadas à seleção $\left(\mathrm{RS}_{\mathrm{p}}\right.$ e $\left.\mathrm{RS}_{8}\right)$, i corresponde ao diferencial de seleção ertandardizado para uma intensidade de seleção de $10 \%$ das progênies, cujo valor é de 1,755 (VENCOVSKY, 1987). Deve-se mencionar que a resposta esperada à seleçăo de progênies de immåos germanos interpopulacionais corsespondo à resposta esperada à seleção de híbridos duplos obtidos de linhagens endogâmicas (SOUZA JÚNIOR, 1992), o que justifica o emprego deste tipo de progênie no presente estudo.

Para verificar as possiveis alteraçð̌es na variabilidade genética devido ao efeito da seleção e do tamanho efetivo restrito dos sintéticos, foram calculados intervalos de 
confiança ao nivel de $5 \%$ de probabilidade $(\alpha=0,05)$ para as variâncias geneticas das progénies $\mathrm{P}$ e $S$, dentro de experimentos $\left(\sigma_{\mathrm{pq} / \mathrm{e}}^{2}, \sigma_{\mathrm{pste}}^{2}\right)$, de acordo com metodologia apjesentada por KNAPP et al. (1987), onde os limites inferior e superior do intervalo são dados, respectivamente, pelas seguintes expressǒes generalizadas:

$$
\left[\mathrm{QM}_{\mathrm{pl}} /(\mathrm{rI})\right]\left\{\left[\left(\mathrm{F}-\mathrm{F}_{1}\right) / \mathrm{F}_{1}\right]+\left[\left(\mathrm{F}_{2} / \mathrm{F}\right)\left(1-\mathrm{F}_{2} / \mathrm{F}_{1}\right)\right]\right\}
$$

$\mathbf{e}$

$$
\left[\mathrm{QM}_{\mathrm{pl}} /(\mathrm{r} \mathrm{I})\right]\left\{\left[\left(\mathrm{F}-\mathrm{F}_{3}\right) / \mathrm{F}_{3}\right]+\left[\left(\mathrm{F}_{4} / \mathrm{F}\right)\left(1-\mathrm{F}_{4} / \mathrm{F}_{3}\right)\right]\right\}
$$

Nestas expreasðes $Q M_{p l}$ representa o quadrado médio da interaçăo "progénies x locais"; r é o número de repetiçōes; 1 é o número de locais; F é a relação entre o quadrado médio de "progênies" e o quadrado médio da interação "progênies x locais";

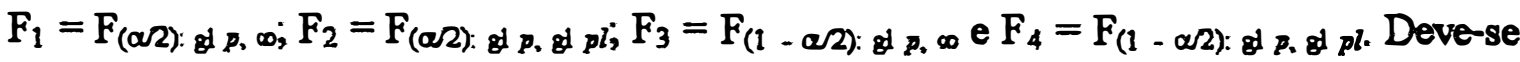
observar que gl $p$ designa o número de graus de liberdade da fonte de variaçăo "progênies", e gl pl o número de graus de liberdade da interação "progênies x locais".

Foram calculados, tamberm, intervalos de confiança ao nivel de $5 \%$ de probabilidade $(\alpha=0,05)$ para os coeficientes de herdabilidade ao nivel de medias das progênies $\mathrm{P}$ e $\mathrm{S}\left(\mathrm{h}_{\mathrm{p}}^{2}, \mathrm{~h}_{\mathrm{s}}^{2}\right)$, sendo os limites inferior e superior do intervalo dados, respectivamente, por (KNAPP et al., 1985):

$$
\left(1-F_{2} / F\right) \text {, e }\left(1-F_{4} / F\right) \text {. }
$$


Visando detectar possiveis alteraçßes na associação entre caracteres, decurrentes do processo seletivo, foram estimados ainda, para os dois tipos de progênies, $\mathrm{P}$ e $\mathrm{S}$, os coeficientes de correlação genética entre as caractensticas avaliadas, de acordo com a seguinte expressão, apresentada por VENCOVSKY \& BARRIGA (1992):

$$
r_{R(X Y)}=\operatorname{COV}_{p(X Y)} / \sqrt{\sigma_{p(X)}^{2} \sigma_{p(Y)}^{2}}
$$

onde:

$I_{g(X)}$ é o coeficiente de correlação genética entre os caracteres X e Y, em questão; $\mathrm{COV}_{\mathrm{P}(X Y)}$ é a covariancia genética, ao nivel de progênies, entre os caracteres X e Y; $\sigma_{q(X)}^{2}$ e $\sigma_{\mathrm{p}(\mathrm{n})}^{2}$ correspondem ds variancias genéticas de progénies para os caracteres X e Y, respectivamente. Deve-se mencionar que as estimativas da covariancia genética foram obtidas pela manipulação dos produtos médios da análise de covariância conjunta agrupada, cujas esperanças matemáticas equivalem às esperanças de quadrados médios apresentadas na Tabela 2, substituindo-se os componentes de variancia pelos respectivos crimpuntentes de covariância (CRUZ \& REGAZZI, 1994).

Finalmente, as distribuiçres de frequência dos dados de medias das 169 progênies de irmāos germanos interpopulacionais de cada cruzamento, foram testadas para normalidade pelo teste W de Shapiro-Wilk (SHAPIRO \& WILK, 1965), e tamberm para assimetria e kurtose, de acordo com metodologia apresentada por SNEDECOR \& COCHRAN (1989), possibilitando avaliar de que mameira os efeitos da seleção e da oscilação genética atuam sobre os padrues de variaçăo dos materiais. 


\section{RESULTADOS E DISCUSSAO}

\subsection{Efeitos da seleçẫo e da oscilação genética nos componentes de médias, heterose e depressão por endogamia}

A precisăo dos experimentos realizados para verificar os efeitos da seleçăo e da oscilação genética sobre componentes de médias, heterose e depressão por endogamia, avaliada atraves do coeficiente de variaga (CV), foi boa em todos os locais e para todos os caracteres avaliados (Tabelas 3, 4 e 5). O menor valor do CV foi observado no Areiḡo (Piracicaba) para o carater posiçăo relativa da espiga na planta $(4,60 \%)$ e o maior, no mesmo local, para o peso de espigas (18,22\%), sendo esta tendencia constante nos demais locais. Deve-se mencionar que as estimativas dos coeficientes de variafă obtidas neste estudo, encontram-se dentro dos limites aceitáveis para a experimentaçăo agronomica e se assemelham aos valores encintrados na literatura da cultura do milho, para todas as caractensticas avaliadas (COORS, 1988; SOUZA JR. \& MIRANDA FILHO, 1989; ARIAS, 1995).

As analises de variância individuais, por local, detectaram diferença altamente significativa $(\mathrm{P}<0,01)$ entre os tratamentro, para todos os caracters avaliados (Tabelas 3, 4 e 5). As médias de tratamentos obtidas em cada local, Andradas, Areiăo e 
Caterpillar, estão apresentadas nas Tabelas 6,7 e 8, respectivamente. O resmmo das aralises de variancia conjuntas, apresentado na Tabela 9, confirma a boa prexisăo experimental obtida nas análises individuais e também evidencia diferença altamente significativa $(P<0,01)$ entre os tratamemtos para todos os caracteites avaliados, exceçăo feita à posição relativa da espiga na planta. Houvo significancia da fonte de variaçăo locais para todas as caractenisticas avaliadas, o que já era esperado em fumçăo das diferentes condiçס̃es dos ambientes em questäo. A interaçăo tratamentos x locais tamberm se mostrou significativa, indicando um compartamento não consistente dos tratamentos nos diferentes locais, para todos os caracteres avaliados.

O desempenho métio dos materiais per se $\left(\mathrm{S}_{0}\right)$, com uma gerafăo de autofecundaçăo $\left(S_{1}\right)$ e em cnzamentos dialélicos (Tabela 10), mostra que, para o caráter peso de espigas, o processo de seleçåo recontente reciproca foi efetivo em melhorar o hibrido interpopulacional, uma vez que o cruamento IG-3 x IG-4 (165,88 g/pl ou 9215 $\mathrm{Kg} / \mathrm{ha}$ ) foi $16,71 \%$ (1319 $\mathrm{Kg} / \mathrm{ha})$ mais proctutivo que o crzamento BR-105 x BR-106 $(142,13 \mathrm{~g} / \mathrm{pl}$ ou $7896 \mathrm{Kg} / \mathrm{ha})$. Tal fato comprova a boa capacidade de complementaça existente entre as populaçőes BR-105 e BR-106, o que já foi observado em outras oportumidades (NASPOLINI FILHO et al., 1981). Deve-se mencionar ainds, que o conamento IG-3 x IG-4 foi 7,64\% (654 Kg/ha) mais produtivo que o melhor hibrido comercial utilizado como testemunha (AG-672 - 154,11 g/pl ou $8561 \mathrm{Kg} / \mathrm{ha}$ ), evidenciando o potencial agronômico desse material (Tabela 10).

No que se refere ao comportamento dos materiais per se, observa-se pela Tabela 10 que a produtividade do sintético IG-3 (134,71 g/pl ou $7484 \mathrm{Kg} / \mathrm{ha}$ ) aumentou $14,77 \%$ (964 Kg/ha) em relaçăo à populaçăo original BR-105 (117,37 g/pl ou $6520 \mathrm{~kg} / \mathrm{ha}$ ), 
enquanto a do sintético IG-4 (129,43 g/pl ou $7190 \mathrm{Kg} / \mathrm{ha})$ sofreu uma redução de 10,13\% (811 Kg/ha) em relação à populaçăo oniginal BR-106 (144,02 g/pl ou $8001 \mathrm{Kg} / \mathrm{ha})$. Estes altos valores de alteraç⿸尸es com o processo seletivo se devem às altas intensidades de seleçåo aplicadas, que foram de $2 \%$ e 2,5\% para a formaça dos sintéticos IG-3 e IG-4, respectivamente.

Estes resultados eståo de acondo com os de outros trabalhos envolvendo o esquema de seleçåo recorrente interpopulacional (MOLL et al., 1978; MOLL \& HANSON, 1984; HELMS et al., 1989), bem como com os resultados teóricos de avaliaçäo deste processo seletivo (SOUZA JR., 1993), que mostram ser este método eficiente em melhorar o hibrido interpopulacional e uma das populaçodes per se, apizentando a populaçáo reciproca ganhos nåo significativos ou, até mesmo, decréscimos significativos no rendimento.

Segundo SOUZA JR. (1993), uma boa alternativa para se contornar cote problema é a utilizaçåo de um método modificado de seleção reconsente, onde uma das populações, a que apresenta menor valor médio para o carater em questăo, é utilizada como testadara dela mesma e da populaça rociproca. Portanto, o método apresenta uma abordagem interpopulacional para a populaça de maior métia e intrapopulacional para a população de menor média. No contexto geral, esse processo parece ser superior aos métodos tradicionais, o que, segundo o autor, está relacionado às magnitudes de novos componentes genéticos de variancia e covarialncia por ele sugeridos.

Com relaçăo aos demais caracteres avaliados, verifica-se que a altura das plantas e das espigas do cruzamento IG-3 x IG-4 foi, respectivamente, 4,87\% e 6,08\% inferior a altura das plantas e espigas do cruzamento BR-105 x BR-106, embora a posiçăo relativa 
da espiga na planta nåo tenha se alterado (Tabela 10). O tndice de prolificidade também foi melhorado, sendo que cada 100 plantas do crizamento IG-3 x IG-4 prohrzem aproximadamente seis espigas a mais que 100 plantas do crizamento BR-105 x BR-106. Estes resultados também evidenciam a eficiência do processo seletivo em melhorar o hibrido interpopulacional.

No que concerme ds populaçães per se, năo foram constatadas diferenças expressivas entre o sintético IG-3 e a populaçåo original BR-105 para a altura da planta e da espiga Já o sintético IG-4 sofreu rochuça na altura da planta $(4,12 \%)$ e da espiga $(3,98 \%)$ quando comprarado com a populaçăo original BR-106. Verifica-se ainda, que a variedade sintética IG-3 apresentou indice de prolificidade 7,23\% superior ao da populaçăo BR-105, mas a IG-4 não apresentou diferenças em relaçăo a populaçăo BR-106 quanto a este carater (Tabela 10).

Os valores de heterose dos cruzamentos (Tabela 11) mostram que, também neste aspecto, o processo de seleçåo reconrente reclproca foi muito eficiente em melhorar o hibrido interpopulacional, uma vez que, para o carater peso de espigas, o criramento original BR-105 x BR-106 apresemtov uma superioridade de 8,75\% (635 Kg/ha) em relaçåo a média das populaçdes parentais, ao passo que o valor de heterose do cruzamento entre os sintéticos IG-3 e IG-4 foi de $25,60 \%$ (1878 Kg/ha), o que representa um aumento de aproximadamente 195\%. As estimativas de heterose dos cuzamentos BR-105 x IG-4 e BR-106 x IG-3 tambm se mostraram superiores em relaçăo d heterose do cruzamento original, confirmando a melhoria da capacidade de combinação dos materiais (Tabela 11). 
Este progresso significativo na heterose pode ser atribuido ds elevadas intensidades de seleção aplicadas sobre as populações BR-105 e BR-106, e tambem foi reportado por outros autores na avaliaçåo do método de seleção recorrente interpopulacional, para a prođuçåo de gräos (EBERHART et al., 1973; PATERNIANI \& VENCOVSKY, 1977). Estudos tebricos realizados por SOUZA JR. \& MIRANDA FILHO $(1985,1989)$ e SOUZA JR. (1993) tambern suportam os resultados ora apresentados, pois evidenciam que a alteraçån na heterose tende a ser positiva na seleçåo interpopulacional, em fumçăo desta fazer uso dos efeitos genéticos aditivos e năo aditivos, nos locos para os quais existe divergência entre as populaçőes e algurm grau de dominância.

Para os caracteres altura da planta e da espiga, verifica-se que os valores de heterose do cruzamento IG-3 x IG-4 foram inferiores aos do cruzamento BR-105 x BR-106, em 54,40\% e 49,77\% respectivamente, o que já era esperado, em funça de a selefåo ter sido praticada no sentido de rechuir a expressåo destes caracteres. Nåo houve alteraçăo no que se refere à posiçăo relativa da espiga na planta, e quanto ao indice de prolificidade foi observada uma melhoria de $100 \%$ na heterose, cmespondente a três espigas em cada 100 plantas (Tabela 11). Estes resultados comprovam, mais uma vez, a eficiência do método de seleção utilizado.

As estimativas de depressåo por endngarnia total das populaçōes BR-105 e BR-106 e dos sintéticos IG-3 e IG-4, bem como as medias esperadas de linhagens retiradas ao acaso destes materiais eståo apresentadas na Tabela 12. Observa-se que, para o caráter peso de espigas, a depressåo por endogamia do sintético IG-3 foi $22,24 \%$ inferior a da população original BR-105, enquanto que para o sintético IG-4, a depressåo por endogamia se manteve nos mesmos niveis da populaçăo original BR-106. Em outras 
palavras, durante o processo seletivo, houve uma redų̧ăo na freguência de alelos recessivos de efeito menns favorável na populaçă BR-105, de modo que quando ocorreu aumento na homozigose do sintético IG-3, o seu desermpenho médio foi menos prejudicado. O mesmo nåo foi observado com a populaçăo BR-106, tałvez devido a um maior efeito do processo aleatório da oscilaçån genética, atuando em sentido cantrário ao do processo seletivo.

De maneira geral, tem sido observada na literatura uma tendência de reduçăo na depressão por endogamia dos materiais suhmetidos aos diferentes métodos de seleção recumente, para o caráter produçăo de grãos (GENTER, 1971; GOULAS \& LONQUIST, 1976; OYERVIDES-GARCIA \& HALLAUER, 1986; MALLAUER et al., 1988; RODRIGUEZ \& HALLAUER, 1988; ODHIAMBO \& COMPTON, 1989). Além disso, estudos teóricos realizados por SOUZA JR. (1985) e por FERNANDES (1990), envolvendo esquemas de seleção intra e interpopulacional, demonstram que a depressăo por endogamia só diminui em populaçỏes com altas frequências dos alelos favoráveis. Estes resultadlos são coerentes com os apresentados neste estudo, ums vez que se espera um aumento na frequécicia dos alelos favoráveis para um grande número de locos, na medida em que se pratica o melhoramento das populaçōes. No caso da populaçăo BR-106, este aumento pode ter sido prejudicado por um maior efeito negativo da oscilaçăo genética, como comentado anteriommente.

Para os demais caracteres, verifica-se que as estimativas da depressåo por endogamia total são de magnitudes bem inferiores àquelas obtidas para o carater peso de espigas (Tabela 12), indicando, a principio, que mesmo nas populaçōes originais, boa parte dos alelos recessivos de efeito menos favorável, relativos a altura da planta e da 
espiga, posição relativa da espiga na planta e indice de prolificidade, já haviam sido eliminados. Contudo, é possivel observar a mesma tendência nas comparaçð̃es feitas entre as populaçōes e seus respectivos sintéticos, ou seja, de maneira geral o sintético IG-3 apresentou valores de depressăo por endogamia total bem inferiores aos da populaçato BR-105, não sendo observadas diferenças expressivas entre o sintético IG-4 e a populaçåo BR-106.

Como consequência destes fatos, as linhagens extraldas ao acaso do sintético IG-3 deveråo ser aproximadamente cinco vezes mais procutivas (2206 Kg/ha) que aquelas oriumdas da populaçåo original BR-105 (472 Kg/ha), além de apresentar maior altura de planta $(19,04 \%)$ e de espiga $(23,46 \%)$ e de produrir 26 espigas a mais em cada 100 plantas. Por seu turno, as linhagens extraidas do sintético IG-4 deveråo apresentar produtividade (1034 $\mathrm{Kg} / \mathrm{ha}$ ) em niveis semelhantes aos obtidos para aquelas oriundas da população original BR-106 (1120 Kg/ha), com menor altura de planta (4,28\%) e de espiga (11,01\%), apesar da produç̧ొo de seis espigas a mais em cada 100 plantas (Tabela 12). Conclui-se, então, que a variedade sintética IG-3 se consiste em germoplasma mais adequado para os programas aplicados de obtenção de hibridos de milho, uma vee que a prochutividade das linhagens está diretamente relacionada ao preço da semente commercial.

O sucesso de qualquer processo seletivo depende do balanço entre duas forças principais que afetam as frequências alélicas de uma populaçăo: seleçăo e oscilaçăo genética. A resposta à seleçăo se dł pelo aumento na frequência de alelos favoráveis e pode ser alcançada pela alteração nos efeitos aditivos, de dominância ou em ambos simultaneamente. Já a oscilą̧ăo genética, que consiste em alteraçớes aleatórias nas frequências alélicas ocorridas em fimçăo do tamanho efetivo populacional recturido, pode 
aumentar a resposta à seleção se atuar na direção da mesma ou pode limitar a resposta, se atuar em sentido oposto ao da seleçăo, o que é mais provável, principalmente nos primeiros ciclos seletivos onde espera-se que as frequências dos alelos favoráveis sejam baixas.

As estimativas dos efeitos genéticos devidos à seleçăo e a oscilaçåo genética, obtidas de acordo com o modelo de SMITH (1979a, b, 1983), apresentaram valores e significalncias muito diferentes para as duas populaçōes estudadas (Tabela 13). Para o carater peso de espigas, observa-se que o parâmetro relativo à contribuiçăo dos efeitos aditivos para o ciclo 0 da populaçåo BR-106 (AOI') foi significativamente diferente de zero $(\mathrm{P}<0,05$ ), o que não se verificou para a populaçăo BR-105 (apesar de AOI nåo apresentar significancia estatística, deve-se observar que sua estimativa merece consideraçăo do ponto de vista agronômico - $472 \mathrm{Kg} / \mathrm{ha}$ ). Por seu tumo, os efeitos de dominancia (DOI e DOI') contributram significativamente para o ciclo 0 de ambas as populaçơes.

O modelo proposto assume que a media do ciclo 0 é dada pela soma AOI + 2DOI, no caso da populaça BR-105 e pos AOI' + 2DOI' para a populaça BR-106, o que caracteriza a propory̧ăo entre os efeitos aditivos e de daminância nas populaçodes originais (AOI:2DOI e AOI':2DOI'). No presente estudo, esta proporça foi de 7\%:93\% para a populaça BR-105 e 14\%:86\% para a populaçăo BR-106 (Tabela 13), evidenciando uma forte preponderância dos efeitos de dominância em ambas as populaçóes originais, o que já foi noticiado por outros autores em pesquisas cam materiais genéticos distintos 
(MELMS et al., 1989; EYHERABIDE \& HALLAUER, 1991; STOJS̆IN \& KANNENBERG, 1994).

Para os caracteres altura da planta e da espiga, houve contribuiçăo significativa dos efeitos aditivos e de dominância para o ciclo 0 das duas populaçðes avaliadas, porén com predominância dos efeitos aditivos. Já para a posiçăo relativa da espiga na planta, somente os efeitos aditivos contribuiram para o ciclo 0 das populaçbes BR-105 e BR-106, e com relaçåo ao tndice de prolificidade, os dois tipos de efeitos, aditivo e dominante, contriburram para o ciclo inicial de ambas as populações, não ocnerendo uma tendência marcante de predominâneia entre eles (Tabela 13).

O processo de seleçăo recorrente reciproca, para o carater peso de espigas, foi efetivo em aumentar a frequência de alelos favoraveis de efeito aditivo na populaça BR-105, mas não foi eficiente em melhorar a contribuiçăo dos efeitos de dominância, uma vez que o parametro ALI foi significativamente positivo, enquanto o parametro DLI não apresentou significância, além de ser negativo (Tabela 13). O inverso ocorreu com a populaçฐ̃ BR-106, ou seja, houve alteraça somente nos locos em heterozigose ou na contribuiçăo dos efeitos de dominância (DLI' significativo e ALI' não significativo e negativo).

O paråmetro ALI foi significativo e positivo enquanto o DLI nåo mostrou significância para a altura da planta e da espigas indicando, na populaçă BR-105, alteraçåo somente nos locos em homozigose, no sentido de aumentar a expressão destes caracteres. Na populaçåo BR-106, o parâmetro ALI' não foi significativo para estas caracteristicas, mas ocorreu alteraçåo significativa na contribuiçăo dos efeitos de 
dominância (DLI') no sentido de aumentar a altura da espiga, caracterizando o oposto do observado para a populaçăo BR-105 (Tabela 13).

Com relaçăo d̀ posição relativa da espiga na planta, năo se venificaram atteraçōes na contribuiçåo dos efeitos aditivos e de dominância em nentruma das populaçőes. Já o que se observa para o mdice de prolificidade em ambas as populaçőes, são alteraçð̃es nos locos em homozigose (ALI e All') contribuindo significativamente para almentar o número de espigas por planta, e alteraçðes nos locos em heterozigose (DLI e DLI') contribuindo para redurir esse número.

As médias esperadas de linhagens retiradas ao acaso das populaçoes e seus respectivos sintéticos $\left(\hat{\overline{\mathrm{L}}}=2 \hat{\overline{\mathrm{S}}_{1}}-\hat{\overline{\mathrm{S}}}_{0}\right)$, podem ser estimadas como uma fumç̧o linear dos parámetros do modelo de SMITH $(1979 a, b, 1983)$ substituindo-se $\bar{S}_{1}$ e $\bar{S}_{0}$ por suas expectativas genéticas. Assim, para a populaçăo BR-105 tem-se $\hat{\mathrm{L}}=$ AÔI e para o sintético IG-3 tem-se $\hat{\overline{\mathrm{L}}}=$ AÔI +2 ẤI (Tabelas 12 e 13). Portanto, a alteraçåo na média das linhagens retiradas ao acaso após um ciclo seletivo é dada pela difereaf̧a entre estas expressões, ou seja, $\Delta \hat{\overline{\mathrm{L}}}=2$ ÂेI . Raciocinio análogo se aplica a populaçă BR-106 e ao sintético IG-4, de modo que $\Delta \hat{\overline{\mathrm{L}}}=2 \mathrm{~A} \hat{\mathrm{LI}}$ '.

Do exposto, é possivel inferir que a alteraçăo na média das linhagens é funçăo somente da alterafă nos locos em homozigose ou da contribuiçă dos efeitos aditivos, o que explica a superioridade das linhagens retiradas ao acaso do sintético IG-3 em relação a populaçăo original BR-105 e a inferioridade das linhagens retiradas ao acaso do sintético IG-4 em relação à populaçăo BR-106 (Tabela 12), tendo em vista as altas 
magnitudes das estimativas positivas de ALI e as baixas magnitudes das estimativas negativas de ALI', para a maioria dos caracteres avaliados (Tabela 13).

O efeito da rectuçảo na heterozigose devido à cscilaçăo genética nas populaçỏes per se (DQI e DQI'), para o carater peso de espigas, foi negativo e significativo em ambas as populaçäes, carrespondendo a -10,96 g/planta (-609 Kg/ha) na populaçăo BR-105 a a $-30,46$ g/planta (-1692 Kg/ha) na populaçåo BR-106 (Tabela 13). Estes valores carrespondem a 2DQI e 2DQI', respectivamente, porque o modelo assume essa ponderaçăo na composiçăo das médias dos sintéticos IG-3 (ciclo 1 da populaçăo BR-105) e IG-4 (ciclo 1 da populaçăo BR-106). As estimativas negativas de DQI e DQI' indicam que os efeitos da oscilação genética limitaram o melhoramento para a produtividade de grăos nas populaçðes per se, como já evidenciado em outros estudos (EYHERABIDE \& HALLAUER, 1991; REERATINIJAKAI \& LAMKEY, 1993; STOJS̆IN \& KANNENBERG, 1994), e explicam a recup̧ăo na produtividade do sintético IO-4 em relaçåo à populaçă onginal BR-106 (Tabela 10), bem como seu elevado valor de depreasso por endogamis total (Tabela 12).

Como já demonstrado, o parâmetro DQI é fumçăo do quadrado da alteraçăo na frequência do alelo favorável por oscilação genetica, e da contribuição dos locos em heteroxigose para o carater $\left[\mathrm{DQI}=\Sigma(\delta \mathrm{p})^{2} \mathrm{~d}\right]$. Sendo assim, a obtençåo de estimativas negativas de DQI (e DQI') poderia ser questionada, pois o quadrado de um desvio [(\$p) $\left.)^{2}\right]$ é sempre positivo, e a contribuiçăo dos locos em heterozigose (d), que currespande a depressão por endogamis total para o carater, de maneire geral, tambem é positiva (Tabela 12). A explicaçăo reside no fato de que no desenvolvimento dos modelos 
originais, o parâmetro DQI apresenta sinal negativo, sendo subtraído na expressăo da expectativa genética, o que nåo é evidenciado no modelo geral ora apresentado, embora o resultado final de sua aplicaçåo seja coerente (Apêndice).

De acordo com o modelo de SMITH (1979a, b, 1983) a média da populaçă melhorada correspondente ao sintético IG-3, é dada por AOI + 2ALI + 2DOI + 2DLI + 2DQI. Como AOI + 2DOI expressa a média da populaça oniginal BR-105, a resposta esperada à seleçåo é fornecida por 2ALI + 2DLI + 2DQI. Pela supressão do paremetro DQI desta expressăo é possivel estimar a resposta esperada à seleçăo, na ausência do efeito da oscilação genética, por 2(ALI + DLI). Racioctnio análogo se aplica ao sintético IG-4, de modo que a resposta esperada à seleçåo na populaçăo BR-106, corrigida pelo efeito da oscilaçăo genética, é dada por 2(ALI' + DLI'). Estas estimativas, juntamente com as respostas observadas à seleçăo, se encontram apresentadas na Tabela 14.

Verifica-se, para o carater peso de espigas, que a resposta esperada d seleçåo, corrigida pelo efeito da oscilaçăo genética, foi $63,32 \%$ (609 $\mathrm{Kg} / \mathrm{ha}$ ) superior à resposta observada na populapăo BR-105. Na populacăo BR-106 a resposta observada foi negativa pois, como comentado anteriommente, o sintético IG-4 foi $811 \mathrm{Kg} / \mathrm{ha}$ menos produtivo que a populaçåo oniginal BR-106, ao passo que a resposta esperada, ajustada para os efeitos da oscilaçåo genética, foi positiva e alta (881 $\mathrm{Kg} / \mathrm{ha})$. Em outras palavras, na ausência de oscilaçåo genética, o sintético IG-4 seria $11,01 \%$ mais produtivo que a populaçåo BR-106.

Os efeitos da oscilação genética também foram prommciados para os caracteres altura da planta e da espiga nas duas populações em questăo. Contudo, nestes casos, estes efeitos atuaram em sentido favorável aos objetivos da seleção, ou seja, no sentido de 
rectuzir a altura da planta e da espiga, tendo em vista a significância das estimativas negativas de DQI e DQI' para estas caractensticas (Tabela 13). O ajuste da resposta esperada pelo efeito da oscilaçăo genética mostrou que as plantas e espigas do sintético IG-3 seriam, respectivamente, $15,26 \mathrm{~cm}$ e $6,26 \mathrm{~cm}$ mais altas que as plantas e espigas da populafăo BR-105, quando a resposta observada carespmides a uma rectuça de $1,10 \mathrm{~cm}$ na altura das plantas e de $1,63 \mathrm{~cm}$ na altura das espigas. No caso da populaça BR-106, a rechucăo de $8,97 \mathrm{~cm}$ na altura das plantas do sintético IG-4 praticamente nåo existinia (-0,54 cm), e a altura das espigas deste material seria $12,60 \mathrm{~cm}$ superior a da populafă criginal, quando observou-se uma rectuçåo de 4,53 cm (Tabela 14).

A posiçăo relativa da espiga na planta nåo foi significativamente afetada pela oscilaçåo genética em nenhuma das populaçōes estudadas mas, o parâmetro DQI, para o indice de prolificidade, se mostrou significativamente negativo, indicando que a oscilaçăo genética ocarreu de maneira a rechuir o número de espigas por planta na populaço BR-105 (Tabela 13). Nesta siturąăo, a resposta esperada à seleçăo, conigida pelo efeito da oscilação genética foi $56,66 \%$ superior a resposta observada, correspondendo a uma diferenca de aproximadamente tres espigas produridas a mais em cada 100 plantas (Tabela 14). Deve-se salientar que os expressivos valores dos efeitos da oscilaça genética observados neste estudo se devem ao tamanho efetivo populacional excessivamente restrito dos sintéticos IG-3 e IG-4.

Os componentes da expressåo da depressåo por endogamia total $\left[\hat{\mathrm{d}}=2\left(\hat{\overline{\mathrm{S}}}_{0}-\hat{\bar{S}}_{1}\right)\right]$ tamberm podem ser substituddos pelas respectivas expectativas genéticas fornecidas pelos parâmetros do modelo de SMITH (1979a, b 1983). Assim, a depressão por endogamia 
total da populaçåo BR-105 comesponde a contribuiçåo dos efeitos de dominancia para o seu ciclo $0(\hat{\mathrm{d}}=2 \mathrm{DÔI})$ e a do sintético IG-3 pode ser dada por $\hat{\mathrm{d}}=2 \mathrm{DÔI}+2 \mathrm{D} \hat{\mathrm{I}}+$ 2DQ̂I (Tabelas 12 e 13). Consequentemente, a diferença entre estas expressōes fornece uma estimativa da alteraçåo ocorrida na depreosão por endogamia total após um ciclo de seleçåo, como $\Delta \hat{\mathrm{d}}=2 \mathrm{D} \hat{\mathrm{L} I}+2 \mathrm{DQ̂} I$. Analogamente, a alteraçåo na populaçăo BR-106 é dada por $\Delta \hat{d}=2 D \hat{L} I^{\prime}+2 D Q ̂ I^{\prime}$.

Portanto, a alteraçåo na depressăo por endogamia total das populaçaes para os sintéticos é funçăo da alteraçåo na contribuição dos efeitos de dominância (DLI e DLI') e dos efeitos da oscilaçăo genética (DQI e DQI'). Observa-se, para a maioria dos caracteres avaliados, que na populaçåo BR-105 as estimativas de DLI não foram significativas, apesar de apresentarem o mesmo sinal das estimativas significativas de DQI, que foi, enţ̊, o principal parámetro responsável pela alteraçăo na depressão por endogamis total. Já na populaçåo BR-106, a maioria das estimativas de DLI' foram significativas e apresentaram sinais contránios às estimativas tambem significativas de DQI', de modo que estes efeitos tenderam a se amular (Tabela 13). Estes resultados explicam a reduçăo na depresså por endogamis do sintético IG-3 em relação à populaçåo original BR-105, e a manutençăo na depressão por endogamia do sintético IG-4 nos mesmos níveis da populaçåo original BR-106 (Tabela 12), evidenciando, tamberm neste aspecto, a importância da oscilaçåo genética.

Os parametros DLII'e DLI'I nåo foram significativos para o carater peso de espigas, indicando que não houve contribuiçăo significativa dos efeitos de dominância das populaçdes BR-105 e BR-106 para o progresso com a seleçåo no hibrido 
imterpopulacional, que foi, portanto, mais determinado pelo melhoramento das populaçбes per se. Contudo, ocorreu alteraçăo significativa na contribuiçăo dos efeitos de dominância das populações BR-105 e BR-106 no sentido de reduzir a altura da planta e da espiga do cruzamento IG-3 x IG-4 (valores significativos e negativos de DLII'e DLI'). Para o caráter indice de prolificidade, estas estimativas tamberm foram significativas, porem de sinais contrários, de modo que hourve alteração nos efeitos de dominalncia da populaç̧̃o BR-105, contribuindo para reduzir o número de espigas por planta no hibrido imterpopulacional, ccnrsendo o oposto para a populaçăo BR-106 (Tabela 13).

Os valores de heterose do cruzamento entre o ciclo 0 da populafăo BR-105 e o ciclo 0 da população BR-106 (HII') furam significativos para todas as caracteristicas avaliadas, com exceçåo da posição relativa da espiga na planta (Tabela 13), e coincidem com as estimativas de heterose apresentadas na Tabela 11. Já o parametro HQF' só foi significativo para o indice de prolificidade, indicando que, para esta caracteristica houve atteraça dos efeitos de dominância no hibrido interpopulacional. A auséncia de significância deste parametro em estudos desta natureza tem sido um fato comum e indica que o processo seletivo utilizado foi eficiente em aumentar a frequência de alelos favoráveis de efeito dominante, em locos diferentes de cada populaça (SMITH, 1983; HELMS et al., 1989; EYHERABIDE \& HALLAUER, 1991; KEERATINIJAKAL \& LAMKEY, 1993).

A alteração na heterose do cruzamento interpopulacional $(\Delta \hat{\mathrm{h}})$ tambem pode ser expressa como uma fimçăo linear dos parametros do modelo de SMITH (1979a, b, 1983). A heterose $\left[\hat{\mathrm{h}}=\hat{\overline{\mathrm{F}}}_{1}-\left(\hat{\overline{\mathrm{P}}}_{1}^{\prime}+\hat{\overline{\mathrm{P}}}_{2}^{\prime}\right) / 2\right]$ do cruzamento original BR-105 x BR-106 e dada por 
$\hat{\mathbf{h}}=$ Hîl' e a do cruzamento melhorado IG-3 x IG-4 por $\hat{\mathbf{h}}=$ HII' ' $+2 D \hat{L I I I '}+2 D \hat{L I I} I$ + 2HQ̂II' - 2DQ̂I - 2DQ̂I'. Verifica-se, então, que a diferença entre estas fumçđes expressa a alteração ocorrida na heterose como $\Delta \hat{\mathrm{h}}=2\left(\mathrm{D} \hat{\mathrm{L}} \Pi^{\prime}+\mathrm{D} \hat{\mathrm{L} I} \mathrm{I}+\mathrm{H} \hat{\mathrm{Q}}{ }^{\prime}\right)$ (DQ̂I + DQ̂I '), e que esta alteraçăo pode ser decommosta em uma parte resultante dos efeitos da seleçåo [2(DLI' + DLI'I + HQII')] e outra resultante dos efeitos da oscilação genética (DQI + DQI') nas populaçðes BR-105 e BR-106.

Pela magnitude dos parametros estimadores de $\Delta \hat{\mathrm{h}}$ (Tabela 13), observa-se que a parte resultante dos efeitos da ascilaçăo genética (DQI + DQI') assumiu um papel findamental na alteraçăo da heterose do cruzamento interpopulacional. Para o caráter peso de espigas, $92,58 \%$ dessa alteração se deveu a provável restituição da condição de heterozigose nos locos onde a oscilaçăo genética atvou, nas duas populaçðes em questån, especialmente na BR-106. Pelo mesmo racioctnio, 33,33\% da alteraça na heterose para o indice de prolificidade ocorreu em fumção dos efeitos da oscilaçăo genética na populaçăo BR-105 (DQI significativo).

No caso da altura da planta e da espigas como a oscilaçăo genética atuou no sentido favorável de recuzir a expressăo destes caracteres, grande parte da reduçăo objetivada na heterose, foi supnimida pela restituição da condiçăo de heterozigose nos locos para os quais a oscilaçăo genética causou fixação de alelos recessivos de efeito mais favorável nas duas populaçðes estudadas. Se fassem descontados DQI e DQI', a alterafăo na heterose para a altura da planta passaria de $-5,93 \mathrm{~cm}$ (Tabela 11) a $-18.34 \mathrm{~cm}$ e para a altura da espiga passaria de $-4,39 \mathrm{~cm}$ a $-16,90 \mathrm{~cm}$ 
Apesar da importância da oscilaçåo genética para a resposts na heterose, a resposta direta à seleçăo no hibrido interpopulacional não é alterads por este fator. De acordo com o modelo de SMITH (1979a, b, 1983) a diferença entre a expectativa genética do cruzamento IG-3 x IG-4 e a expectativa genética do couzamento BR-105 x BR-106, que corresponde à resposta direta no hibrido interpopulacional, equivale a ALI + ALI' + DLI + DLI' + 2DLI' + 2DLI'I + 2HQII' e, partanto, nåo inclui os efeitos da oscilaçăo genética.

Contudo, esta informaça pode ser útil no sentido de quantificar a contribuiçăo de cada populaça para o progresso com a seleçåo no crizamento entre elas. Isto é possivel pela separafăo dos parametros relativos a cada material, de modo que a contribuição da populaçăo BR-105 é dada por ALI + DLI + 2DLI' e a da populaçăo BR-106 por ALI' + DLI' + DLI'I. Estas estimativas se encontram apresentadas na Tabela 14, juntamente com as respostas observadas no hibrido interpopulacional. Deve-se ressaltar que a diferença entre a resposta direta à seleção e a soma das contribuições das populaçães corresponde a 2HQI", parámetro que nomnalmente năo apresenta significância, como comentado anteriormente.

Observa-se, para o carater peso de espigas, que as alteraçoes ocomidas na populaçăo BR-105 apiesentaram maior contribuiçăo para a resposta no híbrido interpopulacional que as alteraçỏes na populaçăo BR-106. Já a reduçåo na altura da planta e da espiga observada no cruzamento IG-3 x IG-4 se deu por uma maior contribuição das alterações sofridas pela populaçåo BR-106 e, no que se refere ao indice de prolificidade, enquanto as mudanças na populafă BR-106 contributram para 
aumentar o numero de espigas por planta no híbrido interpopulacional, as da populaçăo BR-105 contribuiram para rectuzi-lo (Tabela 14).

Deve-se mencionar ainda que, para o carater peso de espigas, que reflete a procutividade dos materiais e, partanto, apresenta maior relevancia neste estudo, a respasta direta à seleçăo recorrente rectproca, ou seja, a resposta no hibrido interpopulacional (1319 Kg/ha), foi de magnitude semelhante à media das respostas indiretas nas populaçðes per se, após o ajuste para os efeitos da oscilaçåo genética (1227 Kg/ha), como se observa na Tabela 14. Resultados semelhantes foram encontrados por outros autores, confirmando a importância da oscilaçåo genética como um fator limitante ao progresso esperado com a seleção para a prochufăo de gråos (SMITH, 1983; HELMS et al., 1989; EYHERABIDE \& HALLAUER, 1991; KEERATINUARAL \& LAMKEY, 1993), sendo indispensível a sua consideraçăo na avaliaçåo dos processos seletivos com a cultura do milho. 


\subsection{Efeitos da seleçăo e da oscilaģa genética na variabilidade genética}

A utilizaçåo do delineamento em látice na avaliaçåo das progênies de irmåos germanos interpopulacionais dos dois tipos de cruzamentos, BR-105 x BR-106 e IG-3 x IG-4, fai uma estrategia correta em todos os experimentos e locais, e para todos os caracteres avaliados, com exceçăo do indice de prolificidade tomado no experimento 1 do Areiăo, como se venifica pelas estimativas de eficiência do látice relacionadas nas Tabelas $15,16,17$ e 18.

A precisåo dos expenimentos 1 e 2, avaliada através do coeficiente de variaçăo (CV), encontra-se dentro dos limites aceitáveis para a expirimentą̧ă agronômica em ambos os locais e para todos os caracteres avaliados, exceçăo feita ao indice de espiga tomado no expenimento 1 do Areif̌o. Observa-se que, de maneira geral, as estimativas do CV para os caracteres peso de espigas e indice de prolificidade foram superiores em relaçăo dquelas obtidas para os caracteres altura da planta, altura da espiga e posição relativa da espiga na planta (Tabelas 15 a 18). Apesar disso, estas estimativas se assemelham aos valores normalmente encontrados na literatura da cultura do milho (COORS, 1988; SOUZA JR. \& MIRANDA FILHO, 1989; ARIAS,1995).

As análises de variancia individuais (Tabelas 15 a 18) mostraram que as progênies de imnåos germanos do cruzamento entre as populaçoes BR-105 e BR-106 (progénies P ou PP), só não se diferenciaram significativamente entre si para o caráter peso de espigas tomado no experimento 2 do Areiăo e para o caráter indice de prolificidade tomado nos dois locais de avaliaçăo do experimento 2. Já as progênies de imãos germanos do cruzamento entre os sintéticos IG-3 e IG-4 (progénies S ou PS) só não apresentaram 
variaģa significativa entre si para o caráter peso de espigas tomado no experimento 1 da Caterpillar e no experimento 2 do Areiăa, e para o carater indice de prolificidade tomado em ambos os locais de avaliaçåo do experimemto 1, e no expenimento 2 do Areiåo.

O contraste entre os dois tipos de progênies, PP e PS, para o carater peso de espigas foi significativo nos experimentos 1 e 2 da Caterpillar, indicando que nestes casos a média das progénies do cnuzamento BR-105 x BR-106 se desviou significativamente da media das progênies do cruzamento IG-3 x IG-4. Para os caracteres altura da planta, altura da espiga e posiçăo relativa da espiga na planta, o contraste PP vs PS foi significativo em todos os experimentas e locais de avaliaçăo, e, no que se refere ao índice de prolificidade, hourve diferença significativa entre as medias dos dois tipos de progênies somente no experimento 2 da Caterpillar (Tabelas 15 a 18).

Uma observaça importante a ser feita é que, para o carater pasiçăo relativa da espiga na planta, apesar do contraste PP vs PS ter se mostrado significativo em todas as situaçőes, as diferenças observadas entre as medias dos dois tipos de progênies foram minimas ou nส̃ existiram, como no caso do experimento 2 da Caterpillar (Tabela 18). Isso ocureu em fumçăo da aproximaçăo numérica realizada, uma vez que as diferenças ocorreram principalmente a partir da segunda ou terceira casa decimal Como a precisåo experimental observada para esta caracteristica foi excelente, essas pequenas diferenças entre os materiais foram detectadas. Este fato indica, pelo menos a princípio, que neste caso a variação estatistica não reflete vaniaçő agronômicas, o que significa dizer que na pratica nåo existiu variabilidade para esta caracterlstica

O resumo das análises de variancia conjuntas realizadas para os experimentos 1 e 2 se encontram apresentados nas Tabelas 19 e 20, respectivamente. Observa-se que apesar 
da proximidade dos dois locais onde foram compuexidas os experimentos, houve diferença significativa entre eles para todos os caracteres avaliados, nos experimentos 1 e 2 , exceçåo feita a altura da planta no experimento 1. As progênies P só não diferiram significativamente entre si para os caracteres peso de espigas e indice de prolificidade tomados no experimento 1. Já as progênies S năo apsesentaram vaniaçåo significativa entre si somente para o carater indice de prolificidade tomado no experimento 2. Houve diferença significativa entre as medias dos dois tipos de progennies, PP e PS, para todos os caracteres tomados nos experimentos 1 e 2 , exceto para o indice de prolificidade no experimento 1 e para o peso de espigas no experimento 2.

Foi observada interaça significativa entre as 85 progênies P do experimento 1 com locais, evidenciando um compurtamento nåo consistente destes materiais nos diferentes locais, para os caracteres peso de espigas e indice de prolificidade. Este fato justifica a ausência de variaç̧o significativa entre estas progênies para estas caracteristicas na análise conjunta do expenimento 1, variaçăo esta que foi observada nas análises individuais (Tabelas 15 e 16). Provavelmente houve anulaçă das difenenças observadas em cada local, quando se considerou a média dos dois ambientes. Já as 84 progênies P do experimento 2 interagiram significativamente com locais somente para a posiçăo relativa da espiga na planta e, no que se refere às progénies $S$ dos expenimentos 1 e 2, não houve interaçăo significativa com locais, para nenhum dos caracteres avaliados (Tabelas 19 e 20).

A interaçăo do contraste PP vs PS com locais foi significativa para os caracteres peso de espigas e posiçăo relativa da espiga na planta, tomados no experimento 1 e para 0 peso de espigas e indice de prolificidade no experimento 2, indicando que nestes casos a 
diferença entre a média das progênies $P$ e a média das progênies $S$ variou significativamente de local para local

Houre homogeneidade dos emos obtidos nas análises conjuntas realizadas para os experimentos 1 e 2, una vez que a relaçâo entre o maior e o menor quadrado médio do restutuo obeervados nestas analises, encontro-se dentro dos limites aceitáveis para a experimentaça agronômica (GOMES, 1973), para todos os caracteres avaliados. Portanto, a partir das análises individuais e das análises conjuntas foi posstvel obter as antises conjumtas agrupadas, que se encontram apresemiadas na Tabela 21. Observa-se, inicialmente, que ocorreu diferença significativa entre os locais Areiảo e Caterpillar, o que năo se verificou entre os experimentos 1 e 2, para todos os caracteres avaliados. A imteraçăo experimentos x locais só năo foi significativa para o peso de espigas, indicando que, para os demais caracteres, houve um comportamento diferencial dos experimentos 1 e 2 nos difierentes locais.

Foi observada significancia para as progênies dos dois tipos de crizamento (PP e PS) dentro de experimentos, para todos os caracteres avaliados, exceto para o indice de prolificidade avaliado nas progênies $\mathrm{P}$, indicando a presença de variabilidade genética nestes materiais. A interaçă progênies dentro de experimentos x locais só foi significativa para o indice de prolificidade avaliado nas progênies $\mathrm{P}$, o que justifica a ausência de variabilidade observada para esta caracterstica, neste material. Para os demais caracteres, portanto, as 169 progénies de cada tipo, PP e PS, apresentaram comportamento consistente nos dois locais onde foram avaliadas (Tabela 21).

O contraste (PP vS PS)/E foi significativo para a altura da planta e da espiga e para a posição relativa da espiga na planta, indicando que, nestes casos, a média das progênies 
P se desviou significativamente da média das progênies $S$, dentro de experimentos. As plantas e espigas das progênies do cnzamento IG-3 x IG-4 (PS) foram, respectivamente, $5,39 \mathrm{~cm}$ e 6,22 cm mais baixas, em média, que as plantas e espigas das progênies do cruzamento BR-105 x BR-106 (PP). Com relaçåo a posição relativa da espiga na planta, vale a ressalva feita anteriomente relativa a significancia do contraste PP vs PS (Tabela 21).

A média das progênies $S$ tambèm foi superior a métia das progênies $P$, para 0 carater peso de espigas $(2,69 \mathrm{~g} / \mathrm{pl}$ ou $150 \mathrm{~kg} / \mathrm{ha})$, apesar da nåo significância do contraste (PP vs PS)/E correspondente. Contudo, esta superioridade foi de magnitude bem menor que a observada nos expenimentos conchuados para se investigar os efeitos da seleçăo e da oscilaçåo genética sobre componentes de médias, heterose e depressåo por endogamia $(23,75 \mathrm{~g} / \mathrm{pl}$ ou $1319 \mathrm{Kg} / \mathrm{ba}$ - Tabela 10). Tal fato pode ser explicado, pelo menos em parte, pelo melhor controle ambiental observado neste último caso (3 locais; 10 repetiçóes / local), frente ao observado no primeiro (2 locais; 2 repetiçóes / local). Além disso, a interaça do contraste (PP vs PS)/E com locais foi significativa para esta caracterdstica mnstrando que, provavelmente, houve anulaçăo das diferenças observadas em cada local, quando se considerou a métia dos dois ambientes (Tabela 21). Portanto, estes resultados tendem a mostrar, mais uma vez, a eficiência do processo seletivo que resultou na obtenção das variedades sintéticas IG-3 e IG-4.

A partir dos quadrados métios das análises conjuntas agrupadas foram obtidas estimativas de componentes de variancia, coeficientes de herdabilidade e progresso esperado com a seleção, para os dois tipos de progênies interpopulacionais (Tabelas 22 e 23). As variancias genéticas das progênies dos dois tipos de cruzamentos, BR-105 x 
BR-106 e IG-3 x IG-4, dentro de experimentos ( $\hat{\sigma}_{p p / e}^{2}$ e $\hat{\sigma}_{p y / e}^{2}$, respectivamente), foram significativamente diferentes de zero para todos os caracteres avaliados, com excegåo da estimativa de $\hat{\sigma}_{\mathrm{pp} / \mathrm{e}}^{2}$ para o indice de prolificidade, como se observa pelos intervalos de confiança obtidos ao ntvel de $5 \%$ de probabilidade para estes parametros. Por estes intervalos de confiança observa-se também que a variância genética das progênies $P$ $\left(\hat{\sigma}_{p p / e}^{2}\right)$ nåo diferru significativamente da variância genética das progênies $S\left(\hat{\sigma}_{\text {pde }}^{2}\right)$, a nåo ser para o carater indice de prolificidade. Pode-se inferir, portanto, que o processo seletivo n:̊o provocou reduf̧å na variabilidade genética dos materiais.

A variância da interaçæo de progênies dentro de experimentos com locais só fói expressiva para o carater indice de prolificidade tomado nas progênies $\mathrm{P}\left(\hat{\sigma}_{(\mathrm{pp} / \mathrm{e}) 1}^{2}\right)$, o que já era esperado em fúmçăo da significância desta fonte de variaçăo na análise conjunta agropada (Tabela 21). Consequenlemente, para esta caracteristica, a variancia fenotipica ao nivel de medias das progênies $P$, dentro de experimentas $\left(\hat{\sigma}_{\text {Fp/e }}^{2}\right)$, foi de magnitude bem superior à estimativa do mesmo componente obtido para as progênies $S\left(\hat{\sigma}_{\mathrm{F} / \mathrm{\varepsilon}}^{2}\right)$, como se verifica na Tabela 22.

De maneira análoga ao observado para as variancias genéticas, as estimativas dos intervalos de confiança obtidos para os coeficientes de herdabilidade mostraram que este parámetro só não foi significativamente diferente de zero $(\mathrm{P}<0,05)$ para as progênies $\mathrm{P}$ $\left(\hat{\mathrm{h}}_{\mathrm{p}}^{2}\right)$, no que se refere ao carater indice de prolificidade. Para os demais caracteres, as estimativas significativas de herdabilidade não foram estatisticamente diferentes para os dois tipos de progênies interpopulacionais, indicando que a variabilidade genética foi 
liberada nas mesmas propory̧o tanto no cruzamento das populaptes BR-105 e BR-106 como no cruzamenjo dos sinteticos IG-3 e IG-4 (Tabelas 22 e 23). Vale mencionar que os valores de herdabilidade foram relativamente altos e coerentes com aqueles normalmente citados na literatura da cultura do milho, para a maioria dos caracteres em questa (HALLAUER \& MIRANDA FILHO, 1981), evidenciando a grande quantidade de variabilidade genética e/ou boa precisåo observadas nos experimentos (Tabelas 22 e 23).

Como consequéncia da manutençăo da variabilidade genética e da herdabilidade dos materiais apos o processo seletivo, para uma intensidade de seleçăo de $10 \%$ a resposta à seleçăo nas progênies $\mathrm{P}\left(\mathrm{RS}_{\mathrm{p}}\right)$ não diferiu da resposta à seleção nas progênies $\mathrm{S}$ $\left(\mathrm{RS}_{\mathrm{z}}\right.$ ), para todos os caracteres avaliados (Tabelas 22 e 23). Portanto, do exposto até aqui, pode-se concluir que, apesar do tamanho efetivo restrito das variedades sintéticas, o efeito conjunto da seleçåo e da oscilaçăo genética parece nåo ter afetado a variabilidade genética e, consequentemente, a resposta esperada a seleçåo nestes materiais. SCHNICKER \& LAMKEY (1993) procuraram detectar alteraços na variabilidade genética do hibrido interpopulacional BSSS x BSCB1, após 11 ciclos de seleção recorrente reciproca para produşă de gråos, e tambemm nåo observaram diferenças significativas entre o hibrido de ciclo 11 e o cruzamento original, no que se refere ds estimativas de parametros genéticos. Esta mesma tendência tem sido verificada em vários outros trabalhos envolvendo diferentes métodos de seleção recorrente (HALLAUER \& MIRANDA FILHO, 1981; HALLAUER, 1984; STUCKER \& HALLAUER, 1992; HOUTHAUS \& LAMKEY, 1995).

Deve-se salientar que algums trabalhos mostram que a variância genética aditiva das populaçס̃es sob melhoramento tende a se reduzir após o primeiro ciclo de seleção, 
apesar de permaner em seguida relativamente constante e em niveis satisfatónios para a continuidade do processo seletivo (WEBEL \& LONQUIST, 1967; COMPTON \& BAHADUR, 1977; RAMALHO 1977; COORS, 1988). Dentre estes autores, algums apontam como causa provável do fato, a utilizaçăo, no primeiro ciclo seletivo, do maximo da variabilidade genética livre existente na populaça, currespondento a segregaça entre blocos poligênicos. Do primeiro ciclo em diante, utiliza-se, em grande parte, a variabilidade genética latente, presente dentro de blocos poligênicos e que é gradativamente liberada pela permuta genética. Por este ponto de vista, a variabilidade live das populaçס̋es consideradas neste estudo năo teria sofrido recu̧̧ă o drástica.

Ressalte-se ainda, o fato de que a variância genética de progênies de irmäos germanos interpopulacionais corresponde a variância genética de hibridos duplos obtidos de linhagens endogâmicas (SOUZA JÚNIOR, 1992). Logo, as respostas esperadas à seleçăo nas progênies $P\left(R_{\mathrm{p}}\right)$ e nas progênies $S\left(\mathrm{RS}_{\mathbf{z}}\right)$ currespondem, respectivamente, ds respostas esperadas à seleção de hibridos duplos de linhagens endogamicas retiradas das populações BR-105 e BR-106 e de hibridos duplos de linhagens endogamicas retiradas dos sintéticos IG-3 e IG-4, ou seja, após o processo de seleçăo recnirente reciproca.

A média dos hibridos duplos selecionados a partir das populaģes BR-105 e BR-106 pode ser expressa por $\overline{\mathrm{HD}}_{\mathrm{p}}=\overline{\mathrm{PP}}+\mathrm{RS}_{\mathrm{p}}$, e a dos hibridos duplos selecionados a partir dos sintéticos IG-3 e IG-4 por $\overline{\mathrm{HD}}_{s}=\overline{\mathrm{PS}}+\mathrm{RS}_{8}$, onde $\overline{\mathrm{PP}}$ e $\overline{\mathrm{PS}}$ representam as medias da interpopulação BR-105 x BR-106 e da interpopulaçăo IG-3 x IG-4, respectivamente. Mas $\overline{\mathrm{PS}}=\overline{\mathrm{PP}}+\mathrm{GS}$, onde GS é o progresso observado com a seleção recorrente reciproca no hibrido interpopulacional e, portanto, $\overline{\mathrm{HD}},=\overline{\mathrm{PP}}+\mathrm{GS}+\mathrm{RS}_{\mathbf{z}}$. 
Do exposto, é possivel medir a alteraçăo ocomida na métia dos hibridos duplos da seguinte maneira: $\Delta H D=\overline{H D}_{z}-\overline{\mathrm{HD}}_{\mathrm{p}}$ ou, $\Delta \mathrm{HD}=\mathrm{GS}+\mathrm{RS}_{\mathbf{z}}-\mathrm{RS}_{\mathrm{p}}$. Como as estimativas de $\mathrm{RS}_{\mathrm{s}}$ e $\mathrm{RS}_{\mathrm{p}}$ foram muito semelhantes para todos os caracteres avaliados neste estudo, estes parâmetros tendem a se amular e a alteraçảo na média dos hibridos duplos praticamente é obtida por $\Delta H D=G S$. Observa-se, então, que o progresso com a seleção de hibridos đuplos é fumçåo direta do progresso com a seleçăo recontente reciproca. Este racioctnio pode ser generalizado para qualquer situaçæo, evidenciando a impurtincia dos métodos de seleção recontente como base para o sucesso dos programas aplicados de obtenção de hibridos de milho.

As estimativas do coeficiente de correlação genética entre os caracteres avaliados se encintram apresentadas na Tabela 24. Verifica-se que aparentemente este parimetro também nåo foi afetado pelo processo seletivo, pois, de maneira geral, caracteres altamente correlacionados na interpopulaf̧̆ BR-105 x BR-106 mantiveram este padrăo de comportamento na interpopilaça IG-3 x IG-4, o mesmo tendendo a oconter para caracteres com baixo grau de associaçăo genética. Esta estabilidade das estimativas do coeficiente de correlaçăo genética após a pratica da seleçăo recorrente é coerente com os resultados obtidos por SCHNICKER \& LAMKEY (1993) e WALTERS et al. (1991). Deve-se mencionar que tanto a magnitude como o sinal das estimativas obtidas se enombram dentro da faixa nonmalmente observada nos estudos com a cultura do milho (HALLAUER \& MIRANDA FILHO, 1981).

Um último aspecto a ser comentado se refere a distribuição das médias das 169 progênies de irmåos germanos interpopulacionais de cada cnuzamento. Para os caracteres 
peso de espigas, altura da planta, altura da espiga e posição relativa da espiga na planta, o teste estatistico W de SHAPIRO \& WILK (1965) para normalidade e os coeficientes de assimetria e kurtose não apresentaram significancia para os dois tipos de progênies, PP e PS (Tabela 25). Isso indica que, para estas caracteristicas, o processo de melhoramento do bibrido interpopulacional se deu sem que houvesse perda de normalidade e presenca de assimetrias na distribuição dos dados.

Com relação ao carater indice de prolificidade, o teste de normalidade $W$ foi significativo para as progênies do cruzamento BR-105 x BR-106 mas não foi para as progénies do cruzamento IG-3 x IG-4, mostrando que a ausência de normalidade na distribuição do hibrido interpopulacional original, deixou de existir após um cicio de seleçăo recorrente reciproca, mesmo com as fortes intensidades de seleção utilizadas neste processo. Já os coeficientes de assimetria e hurtose foram significativos e positivos para os dois tipos de progênies interpopulacionais, indicando que a assimetna à direita e a pequena amplitude de variaç̧o observadas na distribuiçăo das progênies do cruzamento BR-105 x BR-106 se mantiveram na distribuiçåo das progênies do cruzamento IG-3 x IG-4 (Tabela 25).

Do exposto, pode-se dizer que o balanço seleçåo / oscilaçăo genética, observado após um ciclo de intensiva seleção recanente reciproca sobre as populaçðes BR-105 e BR-106, não alterou significativamente os pactöes de vaniaçăo das progênies interpopulacionais, garantindo a integridade da variabilidade genética necessária para a realização de futuros ciclos de seleção. 


\section{CONCLUSÕES}

a) A avaliaçăo das variedades sintéticas de milho IG-3 e IG-4, como resultado de um ciclo de seleção recurrente rectproca com aplicação de elevadas intensidades de seleçăa sobre as populaçðes BR-105 e BR-106, mostrou que o processo seletivo foi eficiente em melhorar a media e a heterose do hibrido interpopulacional e em melhorar a média e rechuzir a depressão por endogamia da populaça BR-105, mas nåo foi efetivo em melhorar a populaçă BR-106, que apresentou decrescimo em seu desempenho individual e manteve seus niveis de depressão por endogamia, para a maioria dos caracteres avaliados. Recomenda-se, do exposto, o emprego da modificaçăo sugerida por SOUZA JR. (1993) para o método de seleção recorrente reciproca, que visa melhorar o desempenho do hibrido interpopulacional e das duas populaçøes per se.

b) De maneira geral, os efeitos significativos da seleção se constituiram por modificaçðes nas frequéncias de alelos de efeito aditivo e dominante na populaçă BR-105 e de alelos de efeito dominante na populafalo BR-106, atuando no sentido de aumentar ou reduzir a expressăo dos caracteres. Já os efeitos da oscilaçăo genética, ocarridos em funçăo da perda de locos em heterozigose, atuaram significativamente no sentido de redurir a expressão da maioria das caracteristicas, em ambas as populaçaes. 
c) Para o carater peso de espigas, de maior impurtância prática, as respostas intiretas esperadas à seleção, conngidas pelo efeito da oscilaçåo genética, foram sempre positivas e de magnituda muito superiores às respostas observadas, indicando que o tamanho efetivo restrito dos sintéticos limitou o melhoramemto das populaçâes per se. Por outro lado, a respasta direta à seleçăo no hibrido interpopulacional năo é aparentemente afetada pela oscilaçåo genética, dependendo apenas dos efeitos da seleção ocorridos em cada populaçăo.

d) A magnitude das alteraçőes observadas na heterose do hibrido interpopulacional e na depressão por endogamia das populaçoes foi fumção de modificaçőes nas frequéncias de alelos de efeito dominante nas populaçaes per se e no hibrido interpopulacional e, principalmente, fumção dos efeitos da oscilaçåo genética. Fica evidenciada, portamto, a importalncia deste componente, se fazendo indispensável a sua consideraçăo na avaliaçăo dos programas de melhoramento com a cultura do milho.

e) Apesar do tamanho efetivo restrito das variedades sintéticas, a interpopulaça IG-3 x IG-4 apresentou diferenças pequenas, parém não significativas em relaçăo a interpopulaçă BR-105 x BR-106, no que se refere à expressă da variabilidade genética e, consequentemente, da resposta esperada à seleção, para a maioria das caractensticas avaliadas. Além disso, o processo de melhoramento do híbrido interpopulacional se deu sem que hourvesse perda de normalidade e presença de assimetrias na distribuição dos dados. Pode-se inferir, portamto, que o efeito conjunto da seleçåo e da oscilaçåo genética n̊̊o afetou significativamente os padrơes de variação das progênies interpopulacionais avaliadas, garantindo a integridade da variabilidade genética necessária para a realizaça de futuros ciclos de seleçåo. 


\section{TABELAS}

Tabela 1. Estrutura da matriz X, formada pelos coeficientes dos parametros do modelo de SMITH (1983), relativos aos materiais BR-105, BR-106, IG-3 e IG-4, per se, autofecundados e em cruzamentos dialélicos.

\begin{tabular}{|c|c|c|c|c|c|c|c|c|c|c|c|c|c|c|}
\hline \multirow[b]{2}{*}{ Tratampertos } & \multicolumn{14}{|c|}{ Parimetinos } \\
\hline & AOI & AOr & ALI & ALS & DOI & DOr & FIII & DUI & DUS & DQI & $\overline{D Q I}$ & DLT & DUII & HQII \\
\hline BR-10S & 1 & 0 & 0 & 0 & 2 & 0 & 0 & 0 & 0 & 0 & 0 & 0 & 0 & 0 \\
\hline BR-106 & 0 & 1 & 0 & 0 & 0 & 2 & 0 & 0 & 0 & 0 & 0 & 0 & 0 & 0 \\
\hline IG-3 & 1 & 0 & 2 & 0 & 2 & 0 & 0 & 2 & 0 & 2 & 0 & 0 & 0 & 0 \\
\hline IG4 & 0 & 1 & 0 & 2 & 0 & 2 & 0 & 0 & 2 & 0 & 2 & 0 & 0 & 0 \\
\hline$B R-10 S S_{1}$ & 1 & 0 & 0 & 0 & 1 & 0 & 0 & 0 & 0 & 0 & 0 & 0 & 0 & 0 \\
\hline$B R-106 S_{1}$ & 0 & 1 & 0 & 0 & 0 & 1 & 0 & 0 & 0 & 0 & 0 & 0 & 0 & 0 \\
\hline$I G-3 S_{n}$ & 1 & 0 & 2 & 0 & 1 & 0 & 0 & 1 & 0 & 1 & 0 & 0 & 0 & 0 \\
\hline$I G-4 S_{1}$ & 0 & 1 & 0 & 2 & 0 & 1 & 0 & 0 & 1 & 0 & 1 & 0 & 0 & 0 \\
\hline BR-105 X BR-106 & $1 / 2$ & $1 / 2$ & 0 & 0 & 1 & 1 & 1 & 0 & 0 & 0 & 0 & 0 & 0 & 0 \\
\hline$B R-105$ XIG-3 & 1 & 0 & 1 & 0 & 2 & 0 & 0 & 1 & 0 & 0 & 0 & 0 & 0 & 0 \\
\hline$B R-105 \times I G-4$ & $1 / 2$ & $1 / 2$ & 0 & 1 & 1 & 1 & 1 & 0 & 1 & 0 & 0 & 0 & 2 & 0 \\
\hline BR-106 XIG-3 & $1 / 2$ & $1 / 2$ & 1 & 0 & 1 & 1 & 1 & 1 & 0 & 0 & 0 & 2 & 0 & 0 \\
\hline BR-106 XIG-4 & 0 & 1 & 0 & 1 & 0 & 2 & 0 & 0 & 1 & 0 & 0 & 0 & 0 & 0 \\
\hline IG-3 XIG-4 & $1 / 2$ & $1 / 2$ & 1 & 1 & 1 & 1 & 1 & 1 & 1 & 0 & 0 & 2 & 2 & 2 \\
\hline
\end{tabular}


Tabela 2. Esquema da análise conjunta agenpado envolvendo experimentos e locais.

\begin{tabular}{|c|c|c|c|}
\hline$\overline{F V}$ & GL & $\overline{Q M}$ & $\mathrm{E}(\mathrm{QM})$ \\
\hline Experimentos (E) & 1 & $\mathrm{Q}_{1}$ & - \\
\hline Locais (L) & 1 & $\mathrm{Q}_{2}$ & - \\
\hline $\mathrm{E} \times \mathrm{L}$ & 1 & $Q_{3}$ & - \\
\hline Progênies (P) / E & 336 & $\mathrm{Q}_{4}$ & - \\
\hline Progênies P (PP) / E & 167 & Qs & $\sigma^{2}+r \sigma_{(p p / e) 1}^{2}+r \sigma_{p p l e}^{2}$ \\
\hline Progênies S (PS) / E & 167 & $Q_{6}$ & $\sigma^{2}+r \sigma_{(p / e) 1}^{2}+r l \sigma_{p y / e}^{2}$ \\
\hline (PP vs PS) / E & 2 & $Q_{7}$ & - \\
\hline$(\mathrm{P} / \mathrm{E}) \times \mathrm{L}$ & 336 & $Q_{8}$ & - \\
\hline$(\mathrm{PP} / \mathrm{E}) \times \mathrm{L}$ & 167 & $Q_{0}$ & $\sigma^{2}+r \sigma_{\left(p^{\prime} /\right) ! 1}^{2}$ \\
\hline (PS/E) $\times L$ & 167 & Q10 & $\sigma^{2}+r \sigma_{(p / e) 1}^{2}$ \\
\hline$[(\mathrm{PP}$ vs $\mathrm{PS}) / \mathrm{E}] \times \mathrm{L}$ & 2 & $Q_{11}$ & - \\
\hline Erro cambinado & 672 & $\mathrm{Q}_{12}$ & $\sigma^{2}$ \\
\hline
\end{tabular}

Obs.: r e l, correspondem, respectivamente, a número de repetições e de locais. 
Tabela 3. Resumo das ańlises de variancia realizadas para os caracteres peso de espigas (PE), altura da planta (AP), altura da espiga (AE), posiçăo relativa da espiga na planta ( $\mathrm{r}$ ) e indice de prolificidade (NE), avaliados nos materiais BR-105, BR-106, IG-3 e IG-4, per se, autofecundados e em cruamentos dialélicos, e nas testemunhas C-855 e AG-672. Andradas, MG. 1994/95.

\begin{tabular}{|c|c|c|c|c|c|c|}
\hline \multirow[b]{2}{*}{ FY } & \multirow[b]{2}{*}{ GL } & \multicolumn{5}{|c|}{$\mathbf{Q M}$} \\
\hline & & PE (\&/pl) & $\mathbf{A P}(\mathbf{c m})$ & $\mathrm{AB}(\mathrm{cm})$ & $r(\mathbf{A E} / \mathbf{A P}) \dagger$ & NE (ब.p/pl)† \\
\hline Blocos & 9 & 349,69 & $681,61 * *$ & $277,83 * *$ & 12,24 & 196,19 \\
\hline Tramentins & 15 & $14572,39 *$ & $1325,08 * *$ & $470,49 *$ & $41,17 *$ & $1160,90 * *$ \\
\hline Erro & 135 & 441,75 & 135,60 & 76,22 & 8,24 & 149,90 \\
\hline CV(\%) & & 15,66 & 5,53 & 8,30 & 5,74 & 14,24 \\
\hline Media & & 134,23 & 210,72 & 105,24 & 0,50 & 0,86 \\
\hline
\end{tabular}

*, **: Significativo ao nivel de $5 \%$ e $1 \%$ de probabilidade, respectivamente.

$t$ : Quactrados medios muttiplicados por $10^{4}$. 
Tabela 4. Resumo das análises de variłncia realizadas para os caracteres peso de espigas (PE), altura da planta (AP), altura da espiga (AE), posição relativa da espiga na planta (r) e indice de prolificidade (NE), avaliados nos materiais BR-105, BR-106, IG-3 e IG-4, per se, autofecundados e em cruzamentos dialélicos, e nas testemunhas C-855 e AG-672. Areião, Piracicaba, SP. 1994/95.

\begin{tabular}{|c|c|c|c|c|c|c|}
\hline \multirow[b]{2}{*}{ FV } & \multirow[b]{2}{*}{ GL } & \multicolumn{5}{|c|}{ QM } \\
\hline & & PE (\&/pl) & $\mathbf{A P}(\mathbf{c m})$ & AB (cm) & $r(\mathrm{AB} / \mathrm{AP}) \dagger$ & NE (esplpl)t \\
\hline Blocos & 9 & 469,50 & $427,08 * *$ & $403,09: 0$ & $47,99 * *$ & 422,09 \\
\hline Tratsmentios & 15 & $10696,54^{* *}$ & $2732,54 * *$ & $1450,39 *$ & 26,41 & 1066,40 \\
\hline Enro & 135 & 502,73 & 168,28 & 85,17 & 6,89 & 211,69 \\
\hline CV(\%) & & 18,22 & 6,12 & 7,66 & 4,60 & 16,92 \\
\hline Medin & & 123,07 & 211,82 & 120,49 & 0,57 & 0,86 \\
\hline
\end{tabular}

*, **: Significativo ao nivel de $5 \%$ e $1 \%$ de probabilidade, respectivamente.

$\uparrow:$ Quadradns medios multiplicados por $10^{4}$. 
Tabela 5. Resumo das analises de variancia realizadas para os caracteres peso de espigas (PE), altura da planta (AP), altura da espiga (AE), posição relativa da espiga na planta (r) e indice de prolificidade (NE), avaliados nos materiais BR-105, BR-106, IG-3 e IG-4, per se, autofecumdados e em covamentos dialélicos, e nas testemumhas C-855 e AG-672. Caterpillar, Piracicaba, SP. 1994/95.

\begin{tabular}{|c|c|c|c|c|c|c|}
\hline \multirow[b]{2}{*}{ FV } & \multirow[b]{2}{*}{ GL } & \multicolumn{5}{|c|}{$\mathbf{Q M}$} \\
\hline & & PE (g/pl) & $\mathrm{AP}(\mathrm{cm})$ & $\mathrm{AE}(\mathrm{cm})$ & $\mathbf{r}(\mathbf{A B} / \mathbf{A P}) \dagger$ & NE (e.p/pl)† \\
\hline Blocos & 9 & 520,97 & 88,06 & 45,90 & 3,69 & 189,54 \\
\hline Iratomentios & 15 & $10071,57^{* *}$ & $1361,82 * *$ & $945,68 *$ & $37,63^{*} *$ & $1167,35^{* *}$ \\
\hline Erro & 135 & 400,38 & 19496 & 138,49 & 11,58 & 200,19 \\
\hline CV(\%) & & 16,27 & 6,78 & 10,68 & 6,42 & 18,86 \\
\hline Media & & 122,99 & 206,04 & 110,24 & 0,53 & 0,75 \\
\hline
\end{tabular}

*, **: Significativo ao nivel de $5 \%$ e $1 \%$ de probabilidade, respectivamente.

†: Quadrados médios multiplicados por $10^{4}$. 
Tabeja 6. Medias obtidas para os caracteres peso de espigas (PE), altura da planta (AP), altura da espiga (AE), posiçăo relativa da espiga na plants (r) e indice de prolificidade (NE), avaliados nos materiais BR-105, BR-106, IG-3 e IG-4, per se, autofecundados e em cruzamentos dialélicos, e nas testemunhas C-855 - AG-672. Andradas, MG. 1994/95.

\begin{tabular}{lccccc}
\hline Tratamento & PE (g/pl) & AP (cm) & AE (cm) & r (AE/AP) & NE (esp/pl) \\
\hline BR-105 & 112,27 & 211,50 & 107,50 & 0,51 & 0,80 \\
BR-106 & 157,42 & 221,60 & 102,40 & 0,46 & 0,93 \\
IG-3 & 136,81 & 204,40 & 104,40 & 0,51 & 0,91 \\
IG-4 & 146,99 & 212,80 & 102,20 & 0,48 & 0,97 \\
BR-105 S 1 & 62,02 & 183,10 & 87,70 & 0,48 & 0,62 \\
BR-106 S 1 & 89,89 & 200,00 & 105,00 & 0,52 & 0,70 \\
IG-3 S 1 & 93,45 & 210,50 & 107,00 & 0,51 & 0,84 \\
IG-4 S1 & 78,85 & 199,60 & 98,00 & 0,49 & 0,73 \\
BR-105 x BR-106 & 148,30 & 221,80 & 105,20 & 0,48 & 0,92 \\
BR-105 x IG-3 & 129,05 & 219,50 & 108,00 & 0,49 & 0,90 \\
BR-105 x IG-4 & 158,86 & 223,50 & 112,50 & 0,50 & 0,94 \\
BR-106 x IG-3 & 180,55 & 228,00 & 114,10 & 0,50 & 0,92 \\
BR-106 x IG-4 & 170,47 & 216,30 & 117,50 & 0,54 & 0,91 \\
IG-3 x IG-4 & 188,49 & 213,10 & 104,80 & 0,49 & 1,00 \\
C-855 & 171,56 & 201,90 & 100,20 & 0,49 & 0,88 \\
AG-672 & 122,78 & 203,90 & 107,40 & 0,52 & 0,76 \\
\hline
\end{tabular}


Tabela 7. MEdias obtidas para os caracteres peso de espigas (PE), altura da planta (AP), altura da espiga (AE), posição relativa da espiga na planta (r) e indice de prolificidade (NE), avaliados nos materiais BR-105, BR-106, IG-3 e IG-4, per se, autofeamdados e em cruzamentos dialélicos, e nas testemunhas C-855 e AG-672. Areiåo, Piracicaba, SP. 1994/95.

\begin{tabular}{lccccc}
\hline Trafarnento & PE (g/pl) & AP $(\mathrm{cm})$ & AE $(\mathrm{cm})$ & r (AE/AP) & NE (esp/pl) \\
\hline BR-105 & 128,97 & 219,50 & 126,30 & 0,58 & 0,97 \\
BR-106 & 143,25 & 220,90 & 126,50 & 0,57 & 0,90 \\
IG-3 & 137,03 & 221,80 & 124,60 & 0,56 & 0,98 \\
IG-4 & 112,42 & 204,80 & 115,70 & 0,56 & 0,85 \\
BR-105 S 1 & 65,74 & 184,90 & 106,10 & 0,57 & 0,66 \\
BR-106 S 1 & 78,86 & 191,90 & 104,70 & 0,54 & 0,71 \\
IG-3 S 1 & 78,25 & 198,10 & 105,90 & 0,53 & 0,71 \\
IG-4 S 1 & 67,90 & 184,10 & 101,40 & 0,55 & 0,72 \\
BR-105 x BR-106 & 148,44 & 233,70 & 136,50 & 0,58 & 0,91 \\
BR-105 x IG-3 & 131,01 & 224,80 & 129,20 & 0,57 & 0,92 \\
BR-105 x IG-4 & 145,39 & 218,20 & 127,90 & 0,59 & 0,95 \\
BR-106 x IG-3 & 140,48 & 226,30 & 133,60 & 0,59 & 0,88 \\
BR-106 x IG-4 & 143,50 & 219,90 & 127,00 & 0,58 & 0,89 \\
IG-3 x IG-4 & 161,95 & 223,10 & 127,60 & 0,57 & 0,96 \\
C-855 & 123,27 & 191,00 & 104,00 & 0,54 & 0,90 \\
AG-672 & 162,61 & 226,20 & 130,90 & 0,58 & 0,90 \\
\hline
\end{tabular}


Tabela 8. Médias obtidas para os caracteres peso de espigas (PE), altura da planta (AP), altura da espiga (AE), posição relativa da espiga na planta ( $r$ ) e incice de prolificidade (NE), avaliados nos materiais BR-105, BR-106, IG-3 e IG-4, per se, autofeeumdados e em cnzamentos dialélicos, e nas testemmhas C-855 e AG-672. Caterpillar, Piracicabe, SP. 1994/95.

\begin{tabular}{lccccc}
\hline Tratamento & PE (g/pl) & AP (cm) & AE (cm) & r (AE/AP) & NE (esp/pl) \\
\hline BR-105 & 110,86 & 203,50 & 109,40 & 0,54 & 0,71 \\
BR-106 & 131,38 & 210,00 & 112,20 & 0,53 & 0,77 \\
IG-3 & 130,30 & 205,00 & 109,30 & 0,53 & 0,77 \\
IG-4 & 128,87 & 208,00 & 109,60 & 0,53 & 0,78 \\
BR-105 S 1 & 61,03 & 193,20 & 97,80 & 0,51 & 0,52 \\
BR-106 S 1 & 77,53 & 197,10 & 103,50 & 0,52 & 0,55 \\
IG-3 S 1 & 89,93 & 197,40 & 104,40 & 0,53 & 0,74 \\
IG-4 S 1 & 75,31 & 180,60 & 91,30 & 0,50 & 0,63 \\
BR-105 x BR-106 & 129,66 & 220,70 & 126,90 & 0,57 & 0,80 \\
BR-105 x IG-3 & 134,51 & 213,10 & 115,40 & 0,54 & 0,80 \\
BR-105 x IG-4 & 144,62 & 216,80 & 121,70 & 0,56 & 0,86 \\
BR-106 x IG-3 & 152,79 & 216,80 & 115,80 & 0,53 & 0,81 \\
BR-106 x IG-4 & 141,89 & 215,50 & 115,50 & 0,53 & 0,79 \\
IG-3 x IG-4 & 147,18 & 207,10 & 113,80 & 0,55 & 0,85 \\
C-855 & 135,05 & 197,70 & 96,20 & 0,50 & 0,77 \\
AG-672 & 176,93 & 221,10 & 121,10 & 0,55 & 0,93 \\
\hline
\end{tabular}


Tabela 9. Resumo das análises de variância conjumtas realizadas para os caracterca peso de espigas (PE), altura da planta (AP), altura da espiga (AE), posiça relativa da espiga na planta ( $\mathrm{r}$ ) e índice de prolificidade (NE), avaliados nos materiais BR-105, BR-106, IG-3 e IG-4, per se, autofecamdados e em cruzamentos dialélicos, e nas testemumbas C-855 e AG-672. Andradas, MG, Aroiăo e Caterpillar, Piracicaba, SP. 1994/95.

\begin{tabular}{|c|c|c|c|c|c|c|}
\hline \multirow[b]{2}{*}{ FV } & \multirow[b]{2}{*}{ GL } & \multicolumn{5}{|c|}{$\overline{Q M}$} \\
\hline & & PE (g/pl) & $\mathrm{AP}(\mathrm{cm})$ & $A E(c m)$ & T(AE/AP) + & NE (cop/pl)t \\
\hline Locais (L) & 2 & $6696,21^{*}$ & $1510,21 *$ & $9671,75^{* *}$ & $1878,28 *$ & 6065,95 ** \\
\hline Blocos / Locais & 27 & 446,72 & 398,92 & 242,27 & 21,20 & 269,15 \\
\hline Tratimatios (T) & 15 & $31622,17^{* *}$ & $4546,41 * *$ & $2292,10 * *$ & 46,50 & $2796,99 * 0$ \\
\hline$T \times L$ & 30 & $1859,17 * *$ & $436,52 * *$ & $287,23 *$ & $29,29 * *$ & 298,62 \\
\hline Erro medio & 405 & 448,28 & 166,28 & 99,96 & 8,90 & 187,23 \\
\hline CV(\%) & & 16,70 & 6,15 & 8,93 & 5,63 & 16,48 \\
\hline Metia & & 126,76 & 209,53 & 111,99 & 0,53 & 0,83 \\
\hline
\end{tabular}

*, **: Significativo ao ntvel de 5\% e $1 \%$ de probabilidade, respectivamente.

$\uparrow$ Quadrados medos multiplicados por $10^{4}$. 
Tabela 10. Medias gerais obtidas para os caracteres peso de espigas (PE), altura da planta (AP), altura da espiga (AE), posiçåo relativa da espiga na planta (r) e índice de prolificidade (NE), avaliados nos materiais BR-105, BR-106, IG-3 e IG-4, per se, autofecumdados e em cruzamentos dialelicos, e nas lestemmhas C-855 e AG-672. Andradas, MG; Areif̃o e Caterpillar, Piracicaba, SP. 1994/95.

\begin{tabular}{lccccc}
\hline Tratamento & PE (g/pl) & AP (cm) & AE (cm) & r (AE/AP) & NE (esp/pl) \\
\hline BR-105 & 117,37 & 211,50 & 114,40 & 0,54 & 0,83 \\
BR-106 & 144,02 & 217,50 & 113,70 & 0,52 & 0,87 \\
IG-3 & 134,71 & 210,40 & 112,77 & 0,53 & 0,89 \\
IG-4 & 129,43 & 208,53 & 109,17 & 0,52 & 0,87 \\
BR-105 S 1 & 62,93 & 187,07 & 97,20 & 0,52 & 0,60 \\
BR-106 S 1 & 82,09 & 196,33 & 104,40 & 0,53 & 0,66 \\
IG-3 S 1 & 87,21 & 202,00 & 105,77 & 0,52 & 0,76 \\
IG-4 S 1 & 74,02 & 188,10 & 96,90 & 0,52 & 0,69 \\
BR-105 x BR-106 & 142,13 & 225,40 & 122,87 & 0,54 & 0,88 \\
BR-105 x IG-3 & 131,52 & 219,13 & 117,53 & 0,53 & 0,87 \\
BR-105 x IG-4 & 149,62 & 219,50 & 120,70 & 0,55 & 0,92 \\
BR-106 x IG-3 & 157,94 & 223,70 & 121,17 & 0,54 & 0,87 \\
BR-106 x IG-4 & 151,95 & 217,23 & 120,00 & 0,55 & 0,86 \\
IG-3 x IG-4 & 165,88 & 214,43 & 115,40 & 0,54 & 0,94 \\
C-855 & 143,29 & 194,53 & 100,13 & 0,51 & 0,85 \\
AG-672 & 154,11 & 217,07 & 119,77 & 0,55 & 0,86 \\
\hline
\end{tabular}


Tabela 11. Heterose $[\hat{\mathrm{h}}, \hat{\mathrm{h}}(\%)]$ dos materiais BR-105, BR-106, IG-3 e IG-4 em cruzamentos dialélicos, para os caracteres peso de espigas (PE), altura da planta (AP), altura da espiga (AE), posiçăo relativa da espiga na planta (r) e indice de prolificidade (NE).

\begin{tabular}{|c|c|c|c|c|c|c|}
\hline Material & Paralmetro & PE $(g / p l)$ & $\mathrm{AP}(\mathrm{cm})$ & $\mathrm{AE}(\mathrm{cm})$ & $\mathrm{r}$ (AE/AP) & NE (esp/pl) \\
\hline \multirow[t]{2}{*}{ BR-105 x BR-106 } & $\hat{\mathbf{h}}$ & 11,44 & 10,90 & 8,82 & 0,01 & 0,03 \\
\hline & $\hat{\mathrm{h}}(\%)$ & 8,75 & 5,08 & 7,73 & 1,89 & 3,48 \\
\hline \multirow[t]{2}{*}{ BR-105 x IG-3 } & $\hat{\mathbf{h}}$ & 5,48 & 8,18 & 3,95 & 0,00 & 0,02 \\
\hline & $\hat{\mathrm{h}}(\%)$ & 4,35 & 3,88 & 3,48 & 0,00 & 1,92 \\
\hline \multirow[t]{2}{*}{ BR-105 x IG-4 } & $\hat{\mathbf{h}}$ & 26,22 & 9,48 & 892 & 0,02 & 0,07 \\
\hline & $\hat{\mathrm{h}}(\%)$ & 21,25 & 4,51 & 7,98 & 3,77 & 8,62 \\
\hline \multirow[t]{2}{*}{ BR-106 x IG-3 } & $\hat{\mathbf{h}}$ & 18,57 & 9,75 & 7,93 & 0,01 & 0,00 \\
\hline & $\hat{\mathrm{h}}(\%)$ & 13,33 & 4,56 & 7,00 & 2,86 & 0,00 \\
\hline \multirow[t]{2}{*}{ BR-106 x IG-4 } & $\hat{\mathbf{h}}$ & 15,22 & 4,21 & 8,57 & 0,03 & 0,00 \\
\hline & $\hat{\mathrm{h}}(\%)$ & 11,13 & 1,97 & 7,69 & 5,77 & 0,00 \\
\hline \multirow[t]{2}{*}{ IG-3 x IG-4 } & $\hat{\mathbf{h}}$ & 33,81 & 4,97 & 4,43 & 0,01 & 0,06 \\
\hline & $\hat{\mathrm{h}}(\%)$ & 25,60 & 2,37 & 3,99 & 2,86 & 6,89 \\
\hline
\end{tabular}


Tabela 12. Depressåo por endogamia total [a, a(\%)] e medtias esperadas de linhagens retiradas ao acaso $(\hat{\mathrm{L}})$ dos materiais BR-105, BR-106, IG-3 e IG-4, para os caracteres peso de espigas (PE), altura da planta (AP), altura da espiga (AE), posiçåo relativa da espiga na planta ( $\mathrm{r}$ ) e indice de prolificidade (NE).

\begin{tabular}{lcccccc}
\hline Material & Paraimetro & PE (g/pl) & AP (cm) & AE (cm) & r (AE/AP) & NE (esp/pl) \\
\hline BR-105 & d & 108,87 & 48,87 & 34,40 & 0,04 & 0,46 \\
& d(\%) & 92,76 & 23,10 & 30,07 & 7,41 & 55,42 \\
& $\hat{\mathrm{L}}$ & 8,49 & 162,63 & 80,00 & 0,50 & 0,37 \\
IG-3 & a & 95,01 & 16,80 & 14,00 & 0,02 & 0,26 \\
& $\mathrm{~d}(\%)$ & 70,52 & 7,98 & 12,41 & 3,77 & 29,21 \\
& $\hat{\mathrm{L}}$ & 39,71 & 193,60 & 98,77 & 0,51 & 0,63 \\
& & & & & & \\
BR-106 & $\mathrm{d}$ & 123,85 & 42,33 & 18,60 & 0,00 & 0,42 \\
& $\mathrm{~d}(\%)$ & 85,99 & 19,46 & 16,36 & 0,00 & 48,27 \\
& $\hat{\mathrm{L}}$ & 20,17 & 175,17 & 95,10 & 0,54 & 0,45 \\
& & & & & & \\
IG-4 & $\mathrm{d}$ & 110,81 & 40,87 & 24,53 & 0,00 & 0,36 \\
& $\mathrm{~d}(\%)$ & 85,62 & 19,60 & 22,47 & 0,00 & 41,37 \\
& $\hat{\mathrm{L}}$ & 18,61 & 167,67 & 84,63 & 0,52 & 0,51 \\
\hline
\end{tabular}


Tabela 13. Estimativas de minimos quadrados dos parametros genéticos do modelo de SMIIH (1983), para os caracteres peso de espigas (PE), altura da planta (AP), altura da espiga (AE), posiçåo relativa da espiga na planta (r) e índice de prolificidade (NE), após um ciclo de seleçåo nas populaçōes de milho BR-105 e BR-106.

\begin{tabular}{|c|c|c|c|c|c|c|}
\hline Popolaça & Parimetro & PE (g/pl) & $\mathbf{A P}(\mathrm{cm})$ & $\mathrm{AB}(\mathrm{cm})$ & $r(\mathbf{A R} / \mathbf{A P}) \dagger$ & NE (exp/pl)t \\
\hline \multirow[t]{6}{*}{ BR-105 } & AOI & 8,49 & $162,63 *$ & $80,00^{*}$ & $30,00^{*}$ & $36,90^{\circ}$ \\
\hline & DOI & $54,44^{*}$ & $24,43^{*}$ & $17,20 *$ & 2,00 & $22,90^{*}$ \\
\hline & ALI & $15,61^{*}$ & $15,48^{*}$ & $9,38^{*}$ & 0,55 & $13,60^{*}$ \\
\hline & DLI & $-1,45$ & $-7,85$ & $-6,25$ & $-0,95$ & $-8,90$ \\
\hline & DQI & $-5,48$ & $-8,18^{*}$ & $-3,95$ & 0,15 & $-1,70^{*}$ \\
\hline & DLI' & 0,83 & $-4,67^{*}$ & $-2,42$ & 0,00 & $-2,85^{*}$ \\
\hline \multirow[t]{6}{*}{ BR-106 } & AOI' & $20,17^{*}$ & $175,17^{*}$ & $95,10^{*}$ & 53,80 & 44,80 \\
\hline & DOI' & $61,92 *$ & $21,17^{*}$ & $9,30 *$ & $-0,70$ & $21,00^{*}$ \\
\hline & ALI & $-0,78$ & $-3,75$ & $-5,23$ & $-1,60$ & $3,55^{*}$ \\
\hline & DL' & $8,71^{*}$ & 3,48 & $11,53^{*}$ & 4,40 & $-4,25 *$ \\
\hline & DQI' & $-15,23 *$ & $-4,22$ & $-8,57^{*}$ & $-2,80$ & 0,65 \\
\hline & DL'I & $-0,22$ & $-2,82 *$ & $-4,23^{*}$ & $-1,15$ & $2,50 *$ \\
\hline BR-105 x & HII' & $11,44^{*}$ & 10,90 & $8,82 *$ & 1,30 & $2,95^{*}$ \\
\hline BR-106 & HQI' & 0,22 & $-1,68$ & $-1,80$ & $-0,40$ & $1,40^{*}$ \\
\hline
\end{tabular}

*: Significativo ao nivel de 5\% de probabilidade.

$\uparrow$ : Valores multiplicados por $10^{2}$. 
Tabela 14. Respostas esperadas à seleção, comigidas pelo efeito da oscilação genética [2(ALI+DLD)], respastas observadas à seleção (entre parênteses), e contribuiçăo para a resposta no hibrido interpopulacional (ALI + DLI + 2DLI'D), para os caracteres peso de espigas (PE), altura da planta (AP), altura da espiga (AE), posiçăo relativa da espiga na planta (r) e indice de prolificidade (NE), após um ciclo de seleção nas populaç̃es de milho BR-105 e BR-106.

\begin{tabular}{|c|c|c|c|c|c|c|}
\hline Popolaçăo & Parûnetro & PE (g/pl) & AP (cm) & $\mathrm{AE}$ (cm) & $r(A E / A P) \dagger$ & NE $(\sigma p / p l) \dagger$ \\
\hline \multirow[t]{3}{*}{ BR-105 } & $2(A L I+D L)$ & 28,32 & 15,26 & 6,26 & $-0,80$ & 9,40 \\
\hline & & $(17,34)$ & $(-1,10)$ & $(-1,63)$ & $(-1,00)$ & $(6,00)$ \\
\hline & $A L I+D L I+2 D L \Pi '$ & 15,81 & $-1,70$ & $-1,70$ & $-0,40$ & $-1,00$ \\
\hline \multirow[t]{3}{*}{ BR-106 } & 2(AU' + DUI') & 15,86 & $-0,54$ & 12,60 & 5,60 & $-1,40$ \\
\hline & & $(-14,59)$ & $(-8,97)$ & $(-4,53)$ & $(0,00)$ & $(0,00)$ \\
\hline & $A L^{\prime}+$ DL' +2DL'I & 7,50 & $-5,90$ & $-2,17$ & 0,50 & 4,30 \\
\hline BR-105 x & & $(23,75)$ & $(-10,97)$ & $(-7,47)$ & $(0,00)$ & $(6,00)$ \\
\hline BR-106 & & & & $=$ & & \\
\hline
\end{tabular}

$\uparrow$ Valores multiplicados por $10^{2}$ 
Tabela 15. Resumo das análises de variância realizadas para os caracteres peso de espigas (PE), altura da planta (AP), altura da espiga (AE), posição relativa da espiga na planta (r) e índice de prolificidade (NE), avaliados em 85 progênies de irmåos germanos do cruzamento entre as populaçōes BR-105 e BR-106 (Progénies P) e 84 progênies de imnåos gemanos do cruzamento entro os sinteticos IG-3 e IG-4 (Progénies S). Experimento 1. Areiåo, Piracicaba, SP. 1994/95.

\begin{tabular}{|c|c|c|c|c|c|c|}
\hline \multirow[b]{2}{*}{ FV } & \multirow[b]{2}{*}{ GL } & \multicolumn{5}{|c|}{$\mathbf{Q M}$} \\
\hline & & PE (g/pl) & AP (cm) & $\mathbf{A E}(\mathrm{cm})$ & $\mathbf{I}(\mathbf{A E} / \mathbf{A P}) \boldsymbol{\dagger}$ & NE (explpl) ${ }^{\dagger}$ \\
\hline Reperiçós & 1 & 2782,34 & 29,59 & 37,78 & 13,96 & 0,48 \\
\hline Progitnies (P) & 168 & 597,30 & $325,80 *$ & $282,00 *$ & $19,00 * *$ & 1238,90 \\
\hline Progenies P (PP) & 84 & 627,49 & $353,71 * *$ & 293,58 & $17,63 * *$ & $2277,73 * *$ \\
\hline Progetries S (PS) & 83 & $572,11^{*}$ & $263,13 * *$ & $200,13 * *$ & $15,85 * *$ & 198,34 \\
\hline PP vs PS & 1 & 152,75 & $3181,97 * *$ & $6105,00 *$ & $395,19 * *$ & 343,66 \\
\hline Erro Efetivo & 144 & 412,85 & 113,68 & 79,26 & 4,73 & 1053,79 \\
\hline $\mathrm{CV}(\%)$ & & 15,42 & 4,67 & 6,66 & 3,75 & 37,29 \\
\hline Media: P & & 131,73 & 227,96 & 133,54 & 0,58 & 0,87 \\
\hline PP & & 132,41 & 231,00 & 137,86 & 0,60 & 0,88 \\
\hline PS & & 131,05 & 224,84 & 129,20 & 0,57 & 0,86 \\
\hline Eficiência do latice & & 102,86 & 110,22 & 102,51 & 100,86 & - \\
\hline
\end{tabular}

*, **: Significativo ao nivel de $5 \%$ e $1 \%$ de probabilidade, respectivamente.

t: Quadrados medios multiplicados por $10^{4}$. 
Tabela 16. Resumo das análises de variância realizadas para os caracteres peso de espigas (PE), altura da planta (AP), ałtura da espiga (AE), posiçăo relativa da espiga na planta (r) e índice de prolificidade (NE), avaliados em 85 progênies de immilos germanos do crzamento entre as populaçoes BR-105 e BR-106 (Progênies P) e 84 progênies de irmâlos gemmanns do crzamento entro os sintéticos IG-3 e IG-4 (Progênies S). Experimento 1. Caterpillar, Piracicaba, SP. $1994 / 95$.

\begin{tabular}{|c|c|c|c|c|c|c|}
\hline \multirow[b]{2}{*}{ FV } & \multirow[b]{2}{*}{ GL } & \multicolumn{5}{|c|}{ QM } \\
\hline & & $\mathrm{PE}(g / \mathrm{pl})$ & $A P(c m)$ & $\mathrm{AE}(\mathrm{cm})$ & $r(A E / A P) \dagger$ & NB (बappl) ${ }^{\dagger}$ \\
\hline Repetifoes & 1 & 4080,43 & 78,61 & 42,60 & 26,57 & 152,85 \\
\hline Proginies (P) & 168 & $721,34^{*}$ & 254,37 & $226,46^{* *}$ & $16,98 * *$ & 300,94 \\
\hline Progenies P (PP) & 84 & $736,94^{*}$ & $255,52^{* *}$ & $221,64^{* *}$ & $14,87^{*}$ & $442,36^{* *}$ \\
\hline Progenies S (PS) & 83 & 641,56 & $219,29 * *$ & $193,83 * *$ & $17,47 * *$ & 161,56 \\
\hline PP v PS & 1 & $6033,35 * *$ & $3070,25 * *$ & $3338,62 * *$ & $178,45^{* *}$ & 0,00 \\
\hline Erro Efetivo & 144 & 539,87 & 77,06 & 66,08 & 6,41 & 234,33 \\
\hline $\mathrm{CV}(\%)$ & & 15,70 & 3,85 & 6,49 & 4,60 & 16,64 \\
\hline Médin: P & & 148,03 & 227,64 & 125,24 & 0,55 & 0,92 \\
\hline PP & & 143,83 & 230,62 & 128,45 & 0,56 & 0,92 \\
\hline PS & & 152,28 & 224,58 & 122,00 & 0,54 & 0,92 \\
\hline Efrièncis do litice & & 103,98 & 100,61 & 100,88 & 102,03 & 100,31 \\
\hline
\end{tabular}

*, **: Significativo ao nivel de $5 \%$ e $1 \%$ de probabilidade, respectivamente.

†: Quadrados médios multiplicados por $10^{4}$. 
Tabela 17. Resumo das análiseo de variância realizadas para os caracteres peso de espigas (PE), altura da planta (AP), altura da espiga (AE), posição relativa da espiga na planta (r) e índice de prolificidade (NE), avaliados em 84 progênies de irmäos germanos do cruzamento entre as populaçסes BR-105 e BR-106 (Progênies P) e 85 progênies de irmåos gemanos do crizamento entre os sintéticos IG-3 e IG-4 (Progênies S). Expenimento 2. Areiăo, Piracicaba, SP. $1994 / 95$.

\begin{tabular}{|c|c|c|c|c|c|c|}
\hline \multirow[b]{2}{*}{ FV } & \multirow[b]{2}{*}{ GL } & \multicolumn{5}{|c|}{ QM } \\
\hline & & PE (\&/pl) & $\mathbf{A P}(\mathrm{cm})$ & $\mathrm{AE}$ (con) & $r(\mathrm{AE} / \mathrm{AP}) \dagger$ & NE (बap/pl) \\
\hline Repeicióes & 1 & 8231,36 & 1,183 & 370,76 & 80,32 & $4196,54 *$ \\
\hline Propines (P) & 168 & 974,42 & $359,52 *$ & $258,59 * *$ & $20,98 * *$ & 293,58 \\
\hline Propgenies P (PP) & 83 & 1177,30 & $324,14 *$ & $299,10 * *$ & $23,08 * *$ & 270,06 \\
\hline Progenies S (PS) & 84 & 774,03 & $380,35 *$ & $198,39 *$ & $18,21 * *$ & 320,21 \\
\hline PP vs PS & 1 & 967,30 & $1546,84 * *$ & $1952,06 * *$ & $79,36 *$ & 8,82 \\
\hline Ero Efetivo & 144 & 891,09 & 134,98 & 116,52 & 8,66 & 260,35 \\
\hline CV(\%) & & 23,42 & 5,06 & 7,99 & 5,07 & 19,92 \\
\hline Media P & & 127,48 & 229,79 & 134,99 & 0,58 & 0,81 \\
\hline PP & & 129,18 & 231,75 & 137,45 & 0,59 & 0,81 \\
\hline P8 & & 125,79 & 227,78 & 132,59 & 0,58 & 0,81 \\
\hline Eficiència do latice & & 111,57 & 123,42 & 117,39 & 102,10 & 104,79 \\
\hline
\end{tabular}

*, **: Significativo ao nivel de $5 \%$ e $1 \%$ de probabilidade, respectivamente.

t: Quadradoo médios multiplicados por $10^{4}$. 
Tabela 18. Resumo das análises de variancia realizadas para os caracteres peso de espigas (PE), altura da planta (AP), altura da espiga (AE), posição relativa da espiga na planta ( $r$ ) e indice de prolificidade (NE), avaliados em 84 progênies de immåos germanos do cruzamento entre as populaçdes BR-105 e BR-106 (Progênies P) e 85 progênies de innăos germanos do crizzamento entro os sintéticos IG-3 e IG-4 (Progênies S). Exparimento 2. Caterpillar, Piracicaba, SP. $1994 / 95$.

\begin{tabular}{|c|c|c|c|c|c|c|}
\hline \multirow[b]{2}{*}{ FV } & \multirow[b]{2}{*}{ GL } & \multicolumn{5}{|c|}{ QM } \\
\hline & & $\mathrm{PE}(\mathrm{g} / \mathrm{pl})$ & $\mathrm{AP}(\mathrm{cm})$ & $A B(\mathrm{~cm})$ & I(AE/AP) & NE (esp/pl)† \\
\hline Repetifoes & 1 & 5226,88 & 73,86 & 0,67 & 2,54 & $1119,28 *$ \\
\hline Progetries (P) & 168 & $723,19 *$ & $270,56 *$ & $183,34 * *$ & $15,57 * *$ & 199,65 \\
\hline Protines P (PP) & 83 & $638,93 *$ & $271,81 * *$ & $185,86 * *$ & $15,60 *$ & 129,74 \\
\hline Progenies 8 (PS) & 84 & $764,94 * *$ & $244,76 *$ & 160,72 & 14,83 & $248,18 *$ \\
\hline PP vs PS & 1 & $4209,43 * *$ & $2334,35 *$ & $1874,93 *$ & $75,24 *$ & $1925,66^{* *}$ \\
\hline Erro Efetivo & 144 & 431,67 & 135,79 & 92,55 & 6,99 & 161,83 \\
\hline CV(\%) & & 14,07 & 5,32 & 8,16 & 4,89 & 13,98 \\
\hline Media: P & & 147,65 & 219,04 & 117,87 & 0,54 & 0,91 \\
\hline PP & & 144,10 & 221,82 & 120,36 & 0,54 & 0,89 \\
\hline P8 & & 151,16 & 216,37 & 115,39 & 0,54 & 0,93 \\
\hline Eficiência do latice & & 108,32 & 107,75 & 112,42 & 102,40 & 102,85 \\
\hline
\end{tabular}

*, **: Significativo ao nivel de $5 \%$ e $1 \%$ de probabilidade, respectivamente.

†: Quadrados médios multiplicados por $10^{4}$. 
Tabela 19. Resumo das andlises de variância conjuntas realizadas para os caracteres peso de espigas (PE), altura da planta (AP), altura da espiga (AE), posição relativa da espiga na planta (r) e Indice de prolificidade (NE), avaliados em 85 progênies de irmälos geimanos do cruzamento entre as populaçoes BR-105 e BR-106 (Progênies P) e 84 progênies de irmăos germanos do crrzamento entre os sintéticos IG-3 e IG-4 (Progênies S). Experimento 1. Areiăo e Caterpillar, Piracicaba, SP. 1994/95.

\begin{tabular}{|c|c|c|c|c|c|c|}
\hline \multirow[b]{2}{*}{ FV } & \multirow[b]{2}{*}{ GL } & \multicolumn{5}{|c|}{ QM } \\
\hline & & PE (g/pl) & $\mathrm{AP}(\mathrm{cm})$ & $A B(\mathrm{~cm})$ & $I(\mathrm{AE} / \mathrm{AP}) \boldsymbol{\dagger}$ & NE (esp/pl) $\dagger$ \\
\hline Locais (L) & 1 & $44885,34^{* *}$ & 19,906 & $11680,62 *$ & $2151,53 *$ & $5048,65 *$ \\
\hline Profinis (P) & 168 & $780,32 * *$ & $474,34 * *$ & $437,22 *$ & $30,05 * *$ & 796,85 \\
\hline Prugtines P (PP) & 84 & 725,51 & $517,33^{* *}$ & $448,24 * *$ & $27,45 * *$ & 1377,75 \\
\hline Prugenias 8 (PS) & 83 & $819,59 *$ & $361,43 * *$ & $315,22 *$ & $26,70 * *$ & 216,01 \\
\hline PP vs PS & 1 & $2124,95^{*}$ & $6234,38 *$ & $9637,54 * *$ & $526,50 * *$ & 210,97 \\
\hline$P \times L$ & 168 & 538,32 & 105,73 & 73,62 & 5,96 & 743,26 \\
\hline$P P \times L$ & 84 & $638,90^{*}$ & 91,90 & 66,98 & 5,04 & $1342,34 * *$ \\
\hline PS $x$ L & 83 & 394,06 & 120,99 & 78,74 & 6,63 & 143,89 \\
\hline$(P P$ ys $P S) \times L$ & 1 & $4061,18^{* *}$ & 0,20 & 206,42 & $27,63 *$ & 168,25 \\
\hline Erro mtdio & 336 & 476,36 & 95,37 & 72,67 & 5,57 & 644,06 \\
\hline $\mathrm{CV}(\%)$ & & 15,60 & 4,28 & 6,59 & 4,14 & 28,20 \\
\hline Mectis: P & & 139,88 & 227,79 & 129,40 & 0,57 & 0,90 \\
\hline PP & & 138,12 & 230,81 & 133,15 & 0,58 & 0,90 \\
\hline PS & & 141,66 & 224,74 & 125,60 & 0,56 & 0,89 \\
\hline
\end{tabular}

* **: Significativo ao nivel de $5 \%$ e $1 \%$ de probabilidade, respectivamente.

t: Quadrados médios multiplicados por $10^{4}$. 
Tabela 20. Resumo das análises de variância conjuntas realizadas para os caracteres peso de espigas (PE), altura da planta (AP), altura da espiga (AE), posição relativa da espiga na planta (r) e indice de prolificidade (NE), avaliados em 84 progênies de imåos germanos do cruzamento entre as populaçőes BR-105 e BR-106 (Progênies P) e 85 progênies de irmāos gemanos do cruzamento entre os sintéticos IG-3 e IG-4 (Progênies S). Experimento 2. Areiăo e Caterpillar, Piracicaba, SP. 1994/95.

\begin{tabular}{|c|c|c|c|c|c|c|}
\hline \multirow[b]{2}{*}{ FV } & \multirow[b]{2}{*}{ GL } & \multicolumn{5}{|c|}{$\mathbf{Q M}$} \\
\hline & & $\overline{\mathrm{PE} \text { (g/pl) }}$ & $\overline{A P(c m)}$ & $\mathrm{AR}(\mathrm{cm})$ & $r(\mathrm{AE} / \mathrm{AP}) \dagger$ & NE (esp/pl) \\
\hline Locais (L) & 1 & $6880294 * 4$ & $19235,56 \%$ & $49694,70 *$ & 4112,76 & $17120,72^{* 4}$ \\
\hline Progirnie (P) & 168 & $1080,45^{* *}$ & $496,95 *$ & $344,49 *$ & 28,00 & $300,67 *$ \\
\hline Progimies P (PP) & 83 & $1256,53 *$ & $448,32 * *$ & $358,74^{* *}$ & $28,40 *$ & $264,27 *$ \\
\hline Progimies S (PS) & 84 & $912,57^{*}$ & $506,30 *$ & $285,88^{* *}$ & $26,06 * *$ & 326,94 \\
\hline PP yo PS & 1 & 568,40 & $3747,84 *$ & $4084,98 *$ & $157,76 *$ & $1115,19 *$ \\
\hline$P \times L$ & 168 & 617,15 & 132,89 & 98,98 & 8,57 & 192,56 \\
\hline$P P \times L$ & 83 & 559,70 & 147,63 & 126,23 & $10,28 *$ & 135,54 \\
\hline$P S \times L$ & 84 & 626,40 & 118,82 & 73,23 & 6,98 & 241,46 \\
\hline$(P P$ vs $P S) \times L$ & 1 & $4608,50 *$ & 91,52 & 0,734 & 0,20 & 817,62 \\
\hline Erro médio & 336 & 661,28 & 135,38 & 104,54 & 7,82 & 211,09 \\
\hline $\mathrm{CV}(\%)$ & & 18,70 & 5,18 & 8,08 & 4,99 & 16,89 \\
\hline Media: P & & 137,57 & 224,42 & 126,43 & 0,56 & 0,86 \\
\hline PP & & 136,64 & 226,79 & 128,90 & 0,56 & 0,85 \\
\hline PS & & 138,48 & 222,08 & 124,00 & 0,56 & 0,87 \\
\hline
\end{tabular}

*, **: Significativo ao ntvel de $5 \%$ e $1 \%$ de probabilidade, respectivamente.

$\uparrow$ Q Quadrados médios multiplicados por $10^{4}$. 
Tabela 21. Resumo das analises de variâncis conjuntas agrupadas realizadas para os caracteres peso de espigas (PE), altura da planta (AP), altura da espiga (AE), posiçăo relativa da espiga na planta (r) e indice de prolificidade (NE), avaliados em 169 progênies de irmăos germanos do cruzamento entre as populaçß̌es BR-105 e BR-106 (Progênies P) e 169 progênies de immåos gemmanos do cruzamento entre os sintéticos IG-3 e IG-4 (Progênies S). Experimentos 1 e 2. Areiåo e Caterpillar, Piracicaba, SP. 1994/95.

\begin{tabular}{|c|c|c|c|c|c|c|}
\hline \multirow[b]{2}{*}{ FV } & \multirow[b]{2}{*}{ GL } & \multicolumn{5}{|c|}{$\overline{Q M}$} \\
\hline & & PE (g/pl) & $\mathbf{A P}(\mathbf{c m})$ & $\mathbf{A E}(\mathbf{c m})$ & r(AE/AP) $\dagger$ & $\mathrm{NE}\left(\boldsymbol{\sigma}_{\mathrm{q} p} / \mathrm{pl}\right) \dagger$ \\
\hline Equimentos (E) & 1 & 1811,42 & 3872,88 & 2961,42 & 84,50 & 4140,00 \\
\hline Locais (L) & 1 & $112390,15^{* *}$ & $10355,05 * *$ & $54601,91 * *$ & $4140,50 * *$ & $19012,50 * *$ \\
\hline$E \times L$ & 1 & 1265,54 & $9192,32 * *$ & $6573,46 * *$ & $84,50 *$ & $2113,00 *$ \\
\hline Progutias (P) / E & 336 & $930,39 * *$ & $485,64 * *$ & $390,85 *$ & $29,02 * *$ & 548,76 \\
\hline Progenies P (PP) / E & 167 & $989,43 * *$ & 483,03 ** & $403,76^{* *}$ & $27,92 * *$ & 821,01 \\
\hline ProgAfries S (PS) / E & 167 & $866,36 * *$ & $434,30 * *$ & $300,46 * *$ & $26,38 * *$ & $271,47^{*}$ \\
\hline$(P P$ v8 PS) / E & 2 & 1346,68 & $4991,11 * *$ & $6861,26 *$ & $342,13 * *$ & 969,60 \\
\hline P/E $\times \mathbf{L}$ & 336 & 577,74 & 119,31 & 86,30 & 7,26 & 467,91 \\
\hline PP/E $\times L$ & 167 & 599,54 & 119,60 & 96,43 & 7,66 & $738,94^{* *}$ \\
\hline P\&E $\times L$ & 167 & 510,93 & 119,90 & 75,97 & 6,80 & 192,67 \\
\hline$[(P P$ vs $P S) \sqrt{E}] \times L$ & 2 & $4334,84 *$ & 45,86 & 103,58 & 13,91 & 819,44 \\
\hline Erro cumbinado & 672 & 568,82 & 115,38 & 88,60 & 6,69 & 427,57 \\
\hline $\operatorname{CV}(\%)$ & & 17,19 & 4,75 & 7,36 & 4,62 & 23,48 \\
\hline Media: P & & 138,72 & 226,10 & 127,91 & 0,56 & 0,88 \\
\hline PP & & 137,38 & 228,80 & 131,02 & 0,57 & 0,88 \\
\hline PS & & 140,07 & 223,41 & 124,80 & 0,56 & 0,88 \\
\hline
\end{tabular}

*, **: Significativo ao nivel de $5 \%$ e $1 \%$ de probabilidade, respectivamente.

†: Quadrados médios multiplicados por $10^{4}$. 
Tabela 22. Estimativas de compomentes de variancia $\left(\hat{\sigma}^{2}, \hat{\sigma}_{\mathrm{p}}^{2}, \hat{\sigma}_{\mathrm{pl}}^{2}, \hat{\sigma}_{\mathrm{P}}^{2}\right)$, coeficientes de herdabilidade $\left(\hat{\mathrm{h}}^{2}\right)$ e respostas esperadas à seleçăo (RS) para os caractereo peso de espigas (PE) e indice de prolificidade (NE), avaliados em 169 progênies de immåos germanos do cruzamento entre as populaçőes BR-105 e BR-106 (Progênies P) e 169 progênies de irmăos germanos do cruzamento entre os sintéticos IG-3 e IG-4 (Progênies S).

\begin{tabular}{|c|c|c|c|}
\hline Material & Parâmetro & PE (g/pl) & NE (esp/pl) † \\
\hline \multirow[t]{6}{*}{ Progênies P } & $\hat{\sigma}^{2}$ & 568,82 & 427,57 \\
\hline & $\hat{\sigma}_{\mathrm{pp} / \mathrm{e}}^{2}$ & $38,87 \leq 97,47 \leq 165,47$ & $-33,33 \leq 20,52 \leq 81,95$ \\
\hline & $\hat{\sigma}_{(p p / c) 1}^{2}$ & 15,36 & 155,50 \\
\hline & $\hat{\sigma}_{\mathrm{Fp} / \mathrm{e}}^{2}$ & 247,36 & 205,25 \\
\hline & $\hat{\mathbf{h}}_{\mathrm{p}}^{2}$ & $0,18 \leq 0,39 \leq 0,55$ & $-0,22 \leq 0,10 \leq 0,34$ \\
\hline & $\mathbf{R S}_{\mathrm{p}}$ & 10,87 & 0,02 \\
\hline \multirow[t]{6}{*}{ Progênies S } & $\hat{\sigma}^{2}$ & 568,82 & 427,57 \\
\hline & $\hat{\sigma}_{p=/ e}^{2}$ & $38,15 \leq 88,86 \leq 148,17$ & $2,29 \leq 19,70 \leq 38,36$ \\
\hline & $\hat{\sigma}_{(p \& / e) 1}^{2}$ & 0,00 & 0,00 \\
\hline & $\hat{\sigma}_{\mathrm{F} / \mathrm{e}}^{2}$ & 216,59 & 67,87 \\
\hline & $\hat{\mathrm{h}}_{\mathrm{g}}^{2}$ & $0,20 \leq 0,41 \leq 0,56$ & $0,04 \leq 0,29 \leq 0,48$ \\
\hline & $\mathbf{R S}_{\mathbf{z}}$ & 10,59 & 0,04 \\
\hline
\end{tabular}

†: Componentes de variância multiplicados por $10^{4}$. 
Tabela 23. Estimativas de componentes de variância $\left(\hat{\sigma}^{2}, \hat{\sigma}_{\mathrm{p}}^{2}, \hat{\sigma}_{\mathrm{pl}}^{2}, \hat{\sigma}_{\mathrm{F}}^{2}\right)$, coeficientes de herdabilidade $\left(\hat{h}^{2}\right)$ e respostas esparadas à seleçåo (RS) para os caracteres altura da planta (AP), altura da espiga (AE) e posiçăo relativa da espiga na planta (r), avaliados em 169 progênies de irmåos germanos do cruramento entre as populaçōes BR-105 e BR-106 (Progênies P) e 169 progênies de immåos germanos do cnizamento entre os sintéticos IG-3 e IG-4 (Progênies S).

\begin{tabular}{|c|c|c|c|c|}
\hline Material & Paralmetro & $\mathrm{AP}(\mathrm{cm})$ & $\mathrm{AE}(\mathrm{cm})$ & $I(\mathrm{AE} / \mathrm{AP}) \uparrow$ \\
\hline \multirow[t]{6}{*}{ Progênies P } & $\hat{\sigma}^{2}$ & 115,38 & 88,60 & 6,69 \\
\hline & $\hat{\sigma}_{p p / e}^{2}$ & $67,56 \leq 90,86 \leq 122,02$ & $57,42 \leq 76,83 \leq 102,86$ & $3,70 \leq 5,06 \leq 6,87$ \\
\hline & $\hat{\sigma}_{(p p / e) 1}^{2}$ & 2,11 & 3,91 & 0,485 \\
\hline & $\hat{\sigma}_{\mathrm{Fp} / \mathrm{e}}^{2}$ & 120,76 & 100,94 & 6,98 \\
\hline & $\hat{\mathbf{h}}_{\mathrm{p}}^{2}$ & $0,66 \leq 0,75 \leq 0,82$ & $0,68 \leq 0,76 \leq 0,82$ & $0,63 \leq 0,72 \leq 0,80$ \\
\hline & $\mathrm{RS}_{\mathrm{p}}$ & 14,51 & 13,42 & 0,03 \\
\hline \multirow[t]{6}{*}{ Progênies S } & $\hat{\sigma}^{2}$ & 115,38 & 88,60 & 6,69 \\
\hline & $\hat{\sigma}_{p / e}^{2}$ & $57,42 \leq 78,60 \leq 106,71$ & $41,60 \leq 56,12 \leq 75,52$ & $3,62 \leq 4,89 \leq 6,60$ \\
\hline & $\hat{\sigma}_{(p / e) 1}^{2}$ & 2,26 & 0,00 & 0,05 \\
\hline & $\hat{\sigma}_{F \& / e}^{2}$ & 108,57 & 75,12 & 6,59 \\
\hline & $\hat{\mathbf{h}}_{\mathbf{3}}^{2}$ & $0,62 \leq 0,72 \leq 0,80$ & $0,66 \leq 0,75 \leq 0,81$ & $0,65 \leq 0,74 \leq 0,81$ \\
\hline & $\mathbf{R S}_{\mathbf{3}}$ & 13,24 & 11,36 & 0,03 \\
\hline
\end{tabular}

$\uparrow:$ Commonentes de variância multiplicados por $10^{4}$. 
Tabela 24. Estimativas de coeficientes de conelaçăo genética $\left(I_{y}\right)$ entre os caracteres peso de espigas (PE), altura da planta (AP), altura da espiga (AE), posição relativa da espiga na planta e indice de prolificidade (NE), avaliados em 169 progênies de imflos germanos do crizamento entre as populaçe BR-105 e BR-106 (Progênies P) e 169 progênies de irmăos germanos do cruzamento entro os sintéticos IG-3 e IG-4 (Progénies S).

\begin{tabular}{|c|c|c|c|c|c|c|}
\hline \multirow[b]{2}{*}{ Mrtaril } & \multirow[b]{2}{*}{ Corter } & \multicolumn{5}{|c|}{$I_{8}$} \\
\hline & & $\mathrm{PE}(\mathrm{g} / \mathrm{pl})$ & $A P(\mathrm{~cm})$ & $\mathbf{A E}(\mathbf{c m})$ & $\mathrm{r}(\mathrm{AE} / \mathrm{AP})$ & NE (esp/pl) \\
\hline \multirow[t]{5}{*}{ Proginis P } & $\mathrm{PE}$ (g/pl) & - & - & - & - & $=$ \\
\hline & $\mathrm{AP}(\mathrm{cm})$ & $0,57^{*}$ & - & - & - & - \\
\hline & $\mathbf{A E}(\mathbf{c m})$ & $0,56^{*}$ & $0,84^{*}$ & - & - & - \\
\hline & $\mathbf{r}(\mathbf{A E} / \mathbf{A P})$ & $0,34^{*}$ & $0,36^{*}$ & $0,81^{*}$ & - & - \\
\hline & NE (exp/pl) & $0,98^{*}$ & 0,11 & 0,09 & 0,03 & - \\
\hline \multirow[t]{5}{*}{ Propinies $S$} & $\mathrm{PE}(g / \mathrm{pl})$ & - & - & - & $=$ & - \\
\hline & $\mathbf{A P}(\mathrm{cm})$ & $0,58 *$ & - & - & - & - \\
\hline & $\mathbf{A E}(\mathbf{c m})$ & $0,42 *$ & $0,77^{*}$ & - & $=$ & - \\
\hline & $r(A E / A P)$ & 0,09 & $0,18^{*}$ & $0,77^{*}$ & * & - \\
\hline & NE (esp/pl) & $0,41 *$ & $0,31^{*}$ & $0,56^{*}$ & $0,58^{*}$ & - \\
\hline
\end{tabular}

*: Significativo ao nivel de $5 \%$ de probabilidade, pelo teste $t$. 
Tabela 25. Teste de nomnalidade (W) e estimativas dos coeficientes de assimetria e kurtose das distribuiçbes de frequência das 169 progênies de immåos gemanos do cruzamento entre as populaço̊es BR-105 e BR-106 (Progênies P) e das 169 progênies de immåos germanos do cruzamento entre os sintéticos IG-3 e IG-4 (Progênies S), para os caracteres peso de espigas (PE), altura da planta (AP), altura da espiga (AE), posiçăo relativa da espiga na planta ( $r$ ) e indice de prolificidade (NE).

\begin{tabular}{|c|c|c|c|c|}
\hline \multirow[b]{2}{*}{ Cutares } & \multirow[b]{2}{*}{ Mrterial } & \multirow[b]{2}{*}{$\mathbf{w}+$} & \multicolumn{2}{|c|}{ Coeficiente } \\
\hline & & & Animetria & Kmbere \\
\hline \multirow[t]{2}{*}{ PE (g/pl) } & Propenta P & 0,98 & $-0,14$ & $-0,16$ \\
\hline & Progetrias S & 0,98 & 0,21 & 0,00 \\
\hline \multirow[t]{2}{*}{$\mathrm{AP}(\mathrm{cm})$} & Propetries P & 0,98 & 0,19 & $-0,17$ \\
\hline & Propernias S & 0,98 & 0,05 & $-0,36$ \\
\hline \multirow[t]{3}{*}{$\mathrm{AE}(\mathrm{cm})$} & Progemies P & 0,99 & 0,22 & 0,16 \\
\hline & Properios S & 0,98 & 0,21 & 0,11 \\
\hline & & & & 桨 \\
\hline \multirow[t]{2}{*}{$r(A E / A P)$} & Propermia P & 0,99 & 0,16 & $-0,09$ \\
\hline & Propetrias S & 0,99 & 0,09 & $-0,41$ \\
\hline \multirow[t]{2}{*}{$\mathrm{NE}(\operatorname{esp} / \mathrm{p})$} & Progetries P & $0,61 * *$ & $6,87^{* *}$ & $71,02 *$ \\
\hline & Progetrias S & 0,98 & $0,32 *$ & $1,44^{* *}$ \\
\hline
\end{tabular}

*, **: Significativo ao nivel de $5 \%$ e $1 \%$ de probabilidade, respectivamente.

†: Teste de nonmalidade de SHAPIRO \& WILK (1965). 


\section{REFERENCIAS BIBLIOGRÁFICAS}

ARIAS, C. A. A. Componentes de variância e covariancia genética relacionados à seleçåo recontente intra e interpopulacional no milho (Zea mays L.). Piracicabe, 1995. 139p. (Dortorado - Escola Superior de Agricultura "Luiz de Queiroz"/USP).

COMPTON, W. A. \& BAHADUR, K. Ten cycles of progress from modified ear-to-row selection in com Crop Sci., Madison, 17: 378-80, 1977.

COMSTOCK, R. E; ROBINSON, H. F; HARVEY, P. H. A breeding procedure designed to make maximum use of both general and specific combining ability. Agron. J., 41: 360-7, 1949.

COORS, J. G. Response to four cycles of combined half-sib and $S_{1}$ family selection in maize. Crop Sci., Madison, 28: 891-6, 1988.

CROW, J. F. Breeding structures of populations. II. Effective population number. In: KEMPIHORNE, O.; BANCROFT, T. A.; GOWEN, J. W.; LUSH, J. L. Statistics and mathematics in Biology. Ames, Iowa State College Press, 1954. p. 543-56. 
CROW, J. F. \& KIMURA, M. An introduction to population genetics theory. New York, Happer \& Row, 1970. 591p.

CRUZ, C. D. \& REGAZZI, A. J. Modelos biométricos aplicados ao melhoromento genético. 1" ed. Viçosa: UFV, Imprensa Universitánia, 1994. 390p.

DARRAH, L. L.; EBERHART, S. A.; PENNY, L. H. Six years of maize selection in Ritale II, Ecuador 573 and Kitale composite A by use of the cumprehensive breeding system Euphytica, Wageningen, 27: 191-204, 1978.

DRAPER, N. R. \& SMTH, H. Applied regression analysis. New york, John Wiley \& Sons, 1966. 407p.

DUDLEY, J. W. \& LAMBERT, R. J. Ninety generations of selection for oil and protein in maize. Maydica, 37: 81-7, 1992.

EBERHART, S. A; DEBEILA, S.; HALLAUER, A. R. Reciprocal recurrent selection in the BSSS and BSCB1 maize varieties and half-sib selection in BSSS. Crop Sci., Madison, 13: 451-6, 1973. 
EYHERABIDE, G. H. \& HALLAUER, A. R. Reciprocal full-sib recurrent selection in maize: II. Contributions of additive, dominance, and genetic drift effects. Crop Sci., Madison, 31: 1442-8, 1991.

FALCONER, D. S. Introduction to quantitative genetics. 3rd ed, Londom, Longman Scientific and Technical, 1989. 438p.

FERNANDES, J. S. C. Progressos esperados em linhagens de mitho (Zea mays L.) via seleçăo recorrente intra e interpopulacional Piracicaba, 1990. 235p. (Doutorado Escola Superior de Agricultura "Luiz de Queiroz" (USP).

GARDNER, C. O. \& EBERHART, S. A. Analysis and interpretation of the variety cross diallel and related populations. Biometrics, Raleigh, 22: 439-51, 1966.

GENTER, C. F. Yields of $S_{1}$ lines from original and advanced synthetic varieties of maize. Crop Sci., Madison, 11: 821-4, 1971.

GENTER, C. F. Companion of $S_{1}$ and testcross after two cycles of recurrent selection in maize. Crop Sci., Madison, 13: 527-37, 1973.

GOMES, F. P. Curso de estatistica experimental. $5^{\text {a }}$ ed. Piracicata, Escola Superior de Agricultura "Luiz de Queiroz" USP, 1973. 430p. 
GOULAS, K. C. \& LONQUIST, J. H Combined half-sib and $S_{1}$ family selection in a maize composite population Crop Sci., Madison, 16: 461-4, 1976.

HALLAUER, A. R. Reciprocal full-sib selection in maize. Crop Sci., Madison, 24: 7559, 1984.

HALLAUER, A. R. \& MIRANDA FILHO, J. B. Quantitative genetics in maize breeding. 1st ed. Ames, Iowa State University Press, 1981. 468p.

HALLAUER, A. R.; RUSSELL, W. A.; LAMKEY, K. R. Com breeding. In: SPRAGUE, G. F. \& DUDLEY, J. W. Corn and corn improvement. 3rd ed. Madison, Am Soc. Agron, 1988. p.463-564.

HAMMOND, J. J. \& GARDNER, C. O. Modification of the variety cross diallel model for evaluating cycles of selection. Crop Sci., Madison, 14: 6-8, 1974.

HELMS, T. C.; HALLAUER, A. R.; SMTTH, O. S. Genetic drift and selection evaluated from recurrent selection programs in maize. Crop Sci., Madison, 29: 602-7, 1989.

HOLTHAUS, J. F. \& LAMKEY, K. R. Population means and genetic variances in selected and unselected Iowa Stiff Stalk synthetic maize populations. Crop Sci., Madison, 35: 1581-9, 1995. 
HULI, F. G. Recursent selection and specific combiring ability in com. J. Am. Soc. Agron., 37: 134-45, 1945.

JENKINS, M T. Segregation of genes affecting yield of grain in maize. J. Am. Soc. Agron., 32: 55-63, 1940.

KEERATINIJAKAL, V. \& LAMKEY, K. R. Genetic effects associated with reciprocal recurent selection in BSSS and BSCB1 maize populations. Crop Sci., Madison, 33: 78-82, 1993.

KNAPP, S. J;; ROSS, W. M; STROUP, W. W. Precision of genetic variance and heritability estimates from sorghum populations. Crop Sci., Madison, 27: 265-8, 1987.

KNAPP, S. J.; STROUP, W. W.; ROSS, W. M. Exact confidence intervals for heritability on a progeny mean basis. Crop Sci., Madison, 25: 192-4, 1985.

LAMKEY, K. R. \& SMTTH, O. S. Perfurmance and inbreding depression of populations representing seven eras of maize breeding. Crop Sci., Madison, 27: 695-9, 1987.

LANDI, P. \& FRASCAROLI, E. Responses to four cycles of full-sib family recumrent selection in an $F_{2}$ maize population. Maydica, 38: 31-7, 1993. 
MALECOT, G. Les mathematiques de l'Hérédité. Paris, Masson et Cie., 1948. 63p.

METTLER, L. E. \& GREGG, T. G. Genética de populaçð̃es e evolução. $1^{\text {a }}$ ed. São Paulo, Poligono, 1969. 262p.

MIRANDA FILHO, J. B. \& VIEGAS, G. P. Milho hibrido. In: PATERNIANI, E. \& VIEGAS, G. P. Melhoramento e produçđo do milho. $2^{2}$ ed. Campinas, Fundação Cargill, 1987. Vol. 1, cap. 7, p. 277-340.

MOLL, R. H; COCKERHAM, C. C.; STUBER, C. W.; WILLIAMS, W. P. Selection responses, genetic-environmental interactions, and heterosis with recurrent selection in maize. Crop Sci., Madison, 18: 599-603, 1978.

MOLL, R. H \& HANSON, W. D. Comparison of effects of intrapopulation versus interpopulation selection in maize. Crop Sci., Madison, 24: 1047-52, 1984.

MOLL, R. H. \& STUBER, C. W. Companisons of resprmse to alternative selection procedures initiated with two populations of maize (Zea mays L.). Crop Sci., Madison, 11: 706-11, 1971.

NASPOLINI FILHO, V.; GAMA, E. E. G.; VIANNA, R. T.; MORO, J. R. General and specific combining ability for yield in a diallel among 18 maize (Zea mays $\mathrm{L}$.) populations. Rev. Brasil. Genet., Ribeiråo Preto, 4: 571-7, 1981. 
ODHIAMBO, M O. \& COMPTON, W. A. Five cycles of reciprocal $S_{1}$ vs. recipracal full-sib index selection in maize. Crop Sci., Madison, 29: 314-9, 1989.

OYERVIDES-GARCIA, M \& HALLAUER, A. R. Selection-induced differences among strains of Iowa Stiff Stalk synthetic maize. Crop Sci., Madison, 26: 506-11, 1986.

PATERNIANI, E. Avaliaçăo do método de seleçăo entre e dentro de familias de meios irmåos no melhoramento do milho (Zea mays L.). Piracicaba, 1968. 92 p. (Docência Catedratica - Escola Superior de Agricultura "Luiz de Queiroz" /USP).

PATERNIANL E. \& MIRANDA FILHO, J. B. Melhoramento de populaçoes. In: PATERNIANI, E. \& VIEGAS, G. P. Methoramento e proctuçdo do milho. 2" ed. Campinas, Fundação Cargill, 1987. Vol. 1, cap. 6, p. 217-74.

PATERNIANI, E. \& VENCOVSKY, R. Reciprocal recurrent selection in maize (Zea mays L.) based on testcrosses of half-sib families. Maydica, 22: 141-52, 1977.

PEREIRA, M B. \& VENCOVSKY, R. Limites da seleção recomente. I. Fatores que afetam o acréscimo das frequências alélicas. Pesq. Agropec. Bras., Brasilią, 23(7): $769-80,1988$. 
RAMALHO, M. A. P. Eficiência relativa de algums processos de seleçăo intrapopulacional no milho (Zea mays L.) baseados em familias ñ̃o endbgamas. Piracicaba, 1977. 122p. (Doutorado - Escola Superior de Agricultura "Luiz de Queiroz'USP).

RODRIGUEZ, O. A. \& HALLAUER, A. R. Effects of recurrent selection in com populations. Crop Sci., Madison, 28: 796-800, 1988.

RUSSELL, W. A.; EBERHART, S. A.; VEGA, U. A. Recurrent selection for specific combining ability for yield in two maize populations. Crop Sci., Madison, 13: 257$61,1973$.

SCHNICKER, B. J. \& LAMKEY, K. R. Interpopulation genetic variance after reciprocal recurrent selection in BSSS and BSCB1 maize populations. Crop Sci., Madison, 33: 90-5, 1993.

SHAPIRO, S. S. \& WIIK, M. B. An analysis of variance test for normality (complete samples). Biometrika, 52: 591-611, 1965.

SMITH, O. S. A model for evaluating progress from recurent selection Crop Sci., Madison, 19: 223-6, 1979a. 
SMITH, O. S. Application of a modified diallel analysis to evaluate recurrent selection for grain yield in maize. Crop Sci., Madison, 19: 819-22, $1979 \mathrm{~b}$.

SMITH, O. S. Evaluation of recurrent selection in BSSS, BSCB1, and BS13 maize populations. Crop Sci., Madison, 23: 35-40, 1983.

SNEDECOR, G. W. \& COCHRAN, W. G. Statistical methods. 8th ed. Ames, Iowa State University Press, 1989. 534p.

SOUZA JR., C. L. Browtures for estimating expected genetic progress in inbred lines via recurrent intrapopulational selection. Rev. Brasil Genet., Ribeiråo Preto, 8(2): 329$42,1985$.

SOUZA JR., C. L. Interpopulation genetic variances and hybrid breeding programs. Rev. Brasil Genet., Ribeirão Preto, 15: 643-56, 1992.

SOUZA JR., C. L. Comparisons of intra-, interpopulation, and modified recurrent selection methods. Rev. Brasil Genet, Ribeirão Preto, 16(1):91-105, 1993.

SOUZA JR., C. L. Manutenção de coleçð̃es de bancos de germoplasmas. Piracicaba, 1995. 28p. (Publicação Didática - Depto. de Genética, Escola Superior de Agricultura "Luiz de Queiroz"/USP). 
SOUZA JR., C. L. \& MIRANDA FILHO, J. B. Alteraçð̃es na heterose via seleção intra e interpopulacional. Pesq. Agropec. Bras., Brasilia, 20(10): 1197-201, 1985.

SOUZA JR., C. L. \& MIRANDA FILHO, J. B. Genetic variability in two maize (Zea mays L.) populations and its relationship with intra- and interpopulation rearrent selection. Rev. Brasil. Genet., Ribeirăo Preto, 12(2): 271-85, 1989.

SOUZA JR., C. L.; SANTOS, M. X.; MAGNAVACA, R.; GAMA, E. E. G. Estimativas de parametros genéticos na interpopulaçă de milho BR-105 x BR-106 e suas implicaçðes no melharamento. Pesq. Agropec. Bras., Brasilia, 28: 473-9, 1993.

SPRAGUE, G. F. \& EBERHART, S. A. Com treering. In: SPRAGUE, G. F. Com and com improvement Agronomy, Madison, 18: 305-62, 1977.

STOJS̆ IN, D. \& KANNENBERG, L. W. Genetic changes associated with different methods of recurrent selection in five maize populations: I. Directly selected traits. Crop Sci., Madison, 34: 1466-72, 1994.

STUCKER, D. S. \& HALLAUER, A. R. Genetic variability as affected by selection in Iowa Stiff Stalk synthetic maize. J. Hered., 83: 410-8, 1992. 
TRAGESSER, S. L.; YOUNGQUIST, W. C.; SMITH, O. S.; COMPTON, W. A. Drift vs. selection effects from five recurrent selection programs in maize. Maydica, 34: 23-32, 1989.

VENCOVSKY, R. Herança Quantitativa. In: PATERNIANI, E. \& VIEGAS, G. P. Melhoramento e produção do milho. $2^{2}$ ed. Campinas, Fundaçăo Cargill, 1987. Vol. 1, cap. 5, p. 137- 216.

VENCOVSKY, R. \& BARRIGA, P. Genética biométrica no fitomelhoramento. $1^{\mathrm{a}}$ ed. Ribeiråo Preto, Revista Brasileira de Genética, 1992. 486p.

WALTERS, S. P.; RUSSELL, W. A.; LAMKEY, K. R. Comparison of phenotypic correlations among $S_{1}$ lines, and their testcrosses, from four Iowa Stiff Stalk populations of maize. Maydica, 36: 39-44, 1991.

WEBEL, O. D. \& LONQUIST, J. H. An evahuation of modified ear-to-row selection in a population of com Crop Sci., Madison, 7: 651-5, 1967.

WRICKE, G. \& WEBER, W. E. Quantitative genetics and selection in plant breending. Berlin, W.G. \& C., 1986. 406p.

WRIGHT, S. Coefficients of inbreeding and relationship. Americ. Nat., 56: 330-8, 1922. 
WRIGHT, S. Evolution in mendelian populations. Genetics, 16: 97-159, 1931. 
